\title{
Data on Uranium and
}

\section{Radium in Ground Water}

in the United States

1954 to 1957

By R. C. SCOTT and F. B. BARKER

GEOLOGICAL SURVEY PROFESSIONAL PAPER 426

A compilation of data collected as part

of a survey of radioelements in the water

resources of the conterminous United States

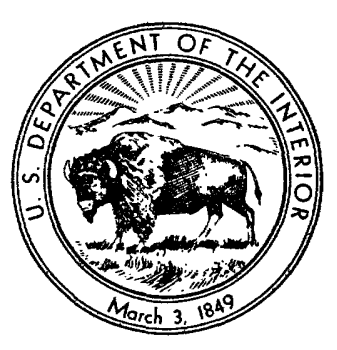

UNITED STATES GOVERNMENT PRINTING OFFICE, WASHINGTON : 1962 


\section{UNITED STATES DEPARTMENT OF THE INTERIOR}

STEWART L. UDALL, Secretary

GEOLOGIGAL SURVEY

Thomas B. Nolan, Director

The U.S. Geological Survey Library has cataloged this publication as follows :

Scott, Robert Clyde, 1921-

Data on uranium and radium in ground water in the United States, 1954 to 1957 , by R. C. Scott and F. B. Barker. Washington, U.S. Govt. Print. Off., 1962.

iii, 115 p. 2 fold. maps (in pocket) diagrs., tables. $29 \mathrm{~cm}$. (U.S. Geological Survey. Professional paper 426)

Bibliography : p. 16.

1. Water, Underground-U.S. 2. Water-Analysis. 3. Water-supply-U.S. 4. Radioactive substances. I. Barker, Franklin Butt, 1923- joint author. II. Title. (Series) 


\section{CONTENTS}

Abstract

Introduction . .

Purpose and scope.....

Acknowledgments............

Collection and examination of samples............

Sampling procedures_._._._.

Selection of sampling sites.........

Method of sample collection........

Chemical and radiochemical analyses..............

Uranium determination

Radium determination. . .

Beta-gamma activity determination...........

Regional distribution characteristics

\begin{tabular}{r|} 
Pase \\
1 \\
1 \\
1 \\
2 \\
2 \\
2 \\
2 \\
2 \\
2 \\
3 \\
3 \\
3 \\
4
\end{tabular}

Interpretation of data

Geotectonic regions.......................... 12

Region I. Atlantic and Gulf Coastal Plain .... $\quad 12$

Region II. Appalachian orogenic belt.......... 13

Region III. Appalachian Plateaus... ....... 13

Region IV. Canadian shield................ 13

Region V. Eastern stable region............ 14

Region VI. Western stable region............ 14

Region VII. Ozark-Ouachila system........... 15

Region VIII. Rocky Mountain orogenic belt..- 15

Region IX. Colorado Plateau ............... 15

Region X. Pacific orogenic belt........... 16

Literature cited._._.

Geologic, hydrologic, and chemical data........... 16

\section{ILLUSTRATIONS}

Plate 1. Map of the conterminous United States showing sampling sites

2. Geotectonic regions of the conterminous United States.

Figure 1-6. Distribution of uranium and radium in samples from geotectonic regions:

1. Region I.

2. Region II

3. Region $V_{2}$

4. Region VI...

5. Region VIII.

6. Region X....

7. Distribution of 80 samples from a synthetic log-normal universe, with true distribution curve....

\section{TABLES}

TABLE 1. Summation of data on concentration of radioelements. 
, 


\title{
DATA ON URANIUM AND RADIUM IN GROUND WATER, IN THE UNITED STATES 1954 TO 1957
}

\author{
BY R. C. SCOTT AND F. B. BARKER
}

\begin{abstract}
This report is one of a series resulting from a study by the U.S. Geological Survey to determine the occurrence and distribution of naturally radioactive substances in water. From 1954-57 uranium and radium concentrations were determined in 561 samples, mainly of ground water, having wide geologic and geographic distribution. These concentrations, together with data on the hydrologic and geologic environment, the betagamma activity, and the chemical characteristics of each sample, are tabulated by States.

The conterminous United States was subdivided into 10 geotectonic regions to facilitate statistical interpretation of the occurrence of uranium and radium in fresh water in approximately homogeneous geologic provinces. For each geotectonic region, the range and median were determined for the concentrations of radium and uranium; for regions from which sufficient data were available, log-normal frequency distribution curves were calculated and superimposed on histograms of radium and uranium concentrations in the samples. An "anomaly threshold" is suggested for both radioelements for each region analyzed statistically. The western stable region had the greatest median and highest "anomaly threshold" for uranium. This region also had the highest "anomaly threshold" for radium, but the largest median for radium was found for samples collected in the Ozark-Ouachita system. The median concentration for uranium was lowest for the Atlantic and Gulf Coastal Plain and the Pacific orogenic belt. This latter region also had the lowest median-radium content.
\end{abstract}

\section{INTRODUCTION}

\section{PURPOSE AND SCOPE}

A study of radioactivity, both naturally occurring and artificially produced, in water was begun in 1952 by the Geological Survey as part of its overall responsibility to evaluate the quantity and quality of the water resources of the Nation. The rather new field, radiohydrology, is broad and includes the investigation of the hydrogeochemistry of the naturally radioactive elements, the use of radioactive tracers in measurements of direction and velocity of water movement, the dispersal of radioactive wastes released to the hydrosphere, the concentration of radioactive substances by waterborne sediments and aquifer material, and other aspects of hydrology in which radioactivity is a factor.
Basic to several of these investigations in the field of radiohydrology is the determination of the occurrence and distribution of naturally radioactive elements in ground water. This investigation was begun in 1952 to (a) determine the natural levels of radioactivity in the ground-water resources of the Nation, (b) evaluate the suitability of these elements as natural tracers or as other aids to hydrologic investigations, and (c) study the hydrogeochemistry of these elements to ascertain some of the functions of water in dissolving, transporting, and depositing mineral matter. The first phase of the investigation involves determining concentrations of radioactive elements in many water samples from sources having wide geologic, hydrologic, and geographic distribution. Most of these samples were defined in terms of their chemical composition and geologic and hydrologic environments to provide usable data for other phases of the investigation.

Uranium and radium were the first radioelements to be investigated for several reasons:

1. The chemistry and the geologic distribution of these elements are such that significant concentrations of them occur in most types of water.

2. Methods of analysis sufficiently sensitive for the low concentrations expected and that could readily be adapted to water analysis were available.

3. Radium-226 is the most hazardous radionuclide according to public health standards, and its physiologic effects are similar to those of several of the fission products. The allowable concentration of these fission products in human-water supplies must therefore be decreased in proportion to the amount of radium-226 present relative to its maximum permissible concentration. Thus, the types and amounts of radioactive waste material that may be released safely in any locality will be limited in part by the concentrations of radium-226 in the water of the area.

4. Uranium is of economic importance; hence, aids to geochemical prospecting, such as data on "normal" concentrations in water, are valuable.

5. Radium-226 is a radioactive daughter of uranium; the two are, therefore, always associated in nature. 
Knowledge of the deviations from equilibrium that may be found in water may lead to a better understanding of some hydrogeochemical processes.

6. The ubiquitous nature of these elements suggests their use as tools in other types of hydrologic investigations.

7. The chemistry of radium is similar to that of the alkaline earth elements; thus, studies of the hydrogeochemical behavior of radium may be extrapolated to trace quantities of certain divalent ions, especially strontium and barium. The chemistry of uranium is similar in some respects to other polyvalent heavy metals; hence, knowledge of the geochemistry of uranium may aid in understanding some types of oreforming processes.

This report is mainly a tabulation of data relating to 561 samples collected before January 1,1958 , in the course of a general reconnaissance of the United States. Information on the geology and hydrology of the aquifer, on the chemical character of the water, and on the uranium and radium content is included. The tabulations given here may be useful to those interested in the concentrations of radium and uranium in water from some of the more important aquifers of the United States.

To aid in comparing characteristics of specific samples to the general radiochemical characteristics of ground-water, the ranges and medians of uranium and radium concentrations in water from various regions of the United States are discussed. Each region is for the most part geologically and hydrologically homogeneous, and the regions provide workable units for deriving statistical parameters that describe the natural distribution of uranium and radium in water. The information presented in the section on regional distribution characteristics represents revisions that bring up-to-date a report previously published in the proceedings of the Second International Conference on Peaceful Uses of Atomic Energy (Scott and Barker, 1958).

\section{ACKNOWLEDGMENTS}

The work described here was conducted under the general supervision of the Chief, Branch of Quality of Water and Chief, Branch of Ground Water. Most of the samples were collected and much of the geologic and hydrologic data were furnished by personnel of the district offices of the Ground Water Branch; the analyses were performed by personnel of the Quality of Water Branch in Washington and Denver. Special thanks are extended to Messrs. R. L. Nace and J. D. Hem, who originally supervised this work and who have been continually helpful even though no longer directly associated with this project.

\section{WATER IN UNITED STATES, 1954 TO 1957}

\section{COLLECTION AND EXAMINATION OF SAMPLES SAMPLING PROCEDURES}

Field personnel were given considerable freedom to select specific sampling sites within their areas of operation because their knowledge of local conditions would aid in selecting sources that would best meet the needs of this study. Most samples were obtained from wells and springs; however, a few samples from lakes and streams were collected for purposes of comparison. Sites at which samples were collected are shown on plate 1 .

\section{SELECTION OF BAMPLING STTES}

A sampling network was designed to give each State as wide a geographic and stratigraphic coverage as possible. When specific sites were being selected for certain stratigraphic units or for a particular region, emphasis was placed first on sources furnishing water for public supplies provided the desired geologic and hydrologic requirements were also satisfied. Some sampling sites, which otherwise would have been desirable, were excluded because well logs or other geologic data were insufficient to identify the aquifer, because wells or springs were dry owing to a drought, or because wells were not equipped with operating pumps.

\section{METHOD OF SAMPLE COLWECTION}

A set of 2 samples of about 2 or 4 liters each and 2 samples of about $100 \mathrm{ml}$ (milliliters) each was collected at each sampling site. To aid in keeping the dissolved uranium and radium in solution until the time of analysis, one large sample was acidified with $8 \mathrm{ml}$ of glacial acetic acid immediately after collection to lower the $\mathrm{pH}$, and at the same time $2 \mathrm{ml}$ of chloroform was added to control algae and fungi growth. The other large sample and the two small ones, to be analyzed for ordinary chemical constituents, were not treated. The samples were shipped to the laboratory as soon as feasible, usually within 3 days after collection.

Samples from wells or developed springs were obtained at the point of discharge or, if the sample was collected from a pipeline, as near the source as possible. Samples from pumped wells were collected after pumps had operated long enough to clear the water that had been standing in the casings; samples from domestic pressure systems, or other sources where storage tanks were used, were obtained if possible after there had been recent turnover of water in the tank. Samples from undeveloped springs and seeps were obtained at their orifices; care was used to avoid sediment and other contaminating material.

\section{CHEMICAL AND RADIOCHEMICAL ANALYSES}

After receipt in the laboratory, the unacidified samples were analyzed for the common chemical con- 
stituents and physical properties according to methods regularly used by the Geological Survey (Rainwater and Thatcher, 1960). A few samples also were analyzed for some of the more uncommon chemical constituents, including sulfide, arsenic, boron, zinc, copper, bromide, iodide, and barium, according to standard methods.

The acidified samples were analyzed for uranium, radium, and gross beta-gamma activity according to methods described briefly below.

\section{URANIUM DETERMINATION}

Concentrations of uranium in the samples were determined by the fluorophotometric method (Thatcher and Barker, 1957). A suitable volume of the sample was evaporated to dryness and fused with a fluoridecarbonate flux. After the melt had solidified and cooled, the intensity of the fluorescence excited by nearultraviolet light was measured photometrically and was compared with that from standard melts containing known amounts of a pure uranium salt.

The precision of this method is about \pm 15 percent of the reported value or $\pm 0.1 \mathrm{ppb}$ (parts per billion), whichever is greater. The accuracy depends somewhat on other constituents of the sample-especially heavy metals-but it is probably within a few percent.

\section{RADTUM DETERMINATION}

Concentrations of radium in the samples were determined by coprecipitating the radium in a suitable volume of sample with barium sulfate and measuring the alpha activity of the precipitate (Barker and Thatcher, 1957). This activity was compared with that of similar precipitate containing a known fraction of a National Bureau of Standards radium-226 standard.

The method described is almost equally sensitive to the three alpha-emitting isotopes of radium when they are present in the precipitate. The amounts of radium226 and radium-224 in the precipitate when the activity is measured are representative of the concentrations in the remainder of the sample at that same time. The concentration of radium-223 in the sample may not be strictly represented by its activity in the precipitate. However, because of the low natural abundance of radium-223 (less than 1 percent as abundant as radium226) in terms of radioactivity and its usual close association with radium-226, errors in the reported quantities of radium probably are negligible. The beta-emitting isotope, radium-228, is not measured by this method; the results, therefore, apply only to the three alpha-emitting isotopes.

The concentration of radium-226 does not measurably change between the time of collection and the time of analysis of the sample, provided there is no precipitation or adsorption within the sample container. Radium-
224, however, has a short half-life; therefore, the concentration depends both on the time between collection and analysis and on the amount of its longlived parent, thorium-228, in the sample. Although the results given in the report apply only to the total radium in the sample at time of analysis, usually 2 to 8 weeks after the time of collection, they can be considered as the maximum concentration of radium-226 at the time of collection and, in fact, often serve as a good approximation to the actual radium-226 concentration. Because of the importance of radium-226 to public health, this limit may be of great significance.

The precision of this method varies with the amount of radium present, but for most samples it is about \pm 20 percent or $\pm 0.1 \mu \mu \mathrm{c}$ per 1 (micromicrocuries per liter), whichever is greater. The accuracy is limited by interferences from other alpha-emitting nuclides, the most important of which are polonium-210 and the alpha-emitting isotopes of thorium. These isotopes give rise to errors respectively equivalent to about onetenth and one-fourth their concentrations in micromicrocuries per liter. These interferences do not detract greatly from the value of the data because the chemistry of these nuclides is such that their concentrations in most natural waters are expected to be rather low. The errors caused by these interferences are no more serious than those caused by interferences in some of the common chemical determinations, such as the usual method of analysis for bicarbonate.

\section{BETA-GAMMA ACTIVITY DETERMINATION}

The gross beta-gamma activities of the samples were determined by measuring the beta-gamma activity of the residue left upon evaporation. A volume of the sample containing about 100 milligrams of solids was evaporated to dryness. The residue was then made into a slurry with distilled water and quantitatively transferred to an aluminum planchet. After the water was removed by drying under an infrared lamp, the activity of the residue was measured with an end window Geiger-Müller counter having a window thickness of 1.4 milligrams per square centimeter and mounted inside an iron shield 2 inches thick.

Such a counter is about 100 percent efficient for the beta particles that penetrate the window. However, of the beta particles that are emitted by the sample the fraction penetrating the window depends partly on absorption in the window, in the air between the sample and the window, and in the sample itself, and partly on scattering from the sample and the planchet. The absorption and scattering vary with the energy of the beta particles; therefore, the overall efficiency is energy dependent. 
The efficiency of a Geiger-Müller counter for photons (mainly gamma rays) depends upon the energy of the radiation; the amounts of absorption and scattering, though small, are also energy dependent. However, the efficiency of the counter is so low for photons, generally only a few percent, that the overall error is increased only slightly.

Each radionuclide is thus counted with a different efficiency which depends on the energy of the radiations and on the ratio of beta particles to gamma rays emitted. Counting data can be exactly transformed into units of radioactivity only when the radionuclides present are known, and even then only with difficulty if the mixture is complex. Thus, the selection of one reference nuclide, in terms of which all data could be reported, was deemed desirable. Thallium-204 was chosen for this study because of its availability in standardized form, its rather average beta energy, and its widespread use as a standard of comparison for unknown fission product mixtures. All beta-gamma results listed in this report, therefore, represent the amount of thallium-204 activity that would produce the same counting rate as the sample when measured by the techniques and instruments described. The results thus serve for intercomparison of samples, though they cannot be interpreted in absolute terms. The fact that the results depend on the instrumentation and sample mounts precludes exact comparison of results obtained by the Geological Survey laboratories with those obtained by other workers using different instruments. However, the order of magnitude of the results should be comparable.

The precision of this determination depends largely on the background counting rate of the instruments and on the level of activity in the sample volume used. The standard deviation of a net counting rate (Friedlander and Kennedy, 1955, p. 252-265) is given by

where

$$
\sigma=\sqrt{\left(R / t_{r}\right)+\left(B / t_{b}\right)}
$$

$\sigma=$ standard deviation of the net counting rate

$R=$ gross counting rate, sample plus background

$B=$ background counting rate

$t_{r}=$ time during which sample was counted

$t_{b}=$ time during which background was counted.

A given net counting rate $(N=R-B)$ is considered to be significant only when it lies more than two standard deviations above zero; that is

$$
\begin{aligned}
& N-2 \sigma>0 \\
& N>2 \sqrt{\left(R / t_{r}\right)+\left(\overline{B / t_{b}}\right)} .
\end{aligned}
$$

For counting rates near the detection limit $(R \approx B)$ and where both counting times are approximately the same (the condition under which these samples were counted), the equation reduces to

$$
N>2 \sqrt{2(B / t)} \text {. }
$$

For the instruments and counting times used in collecting these data, the minimum detectable activity is found to be from 3.5 to $5 \mu \mu \mathrm{c}$. The sample volume used depends on the solid content of the sample; thus, the minimum concentration that may be detected varies with the total amount of mineral matter in solution.

The certainty is less than 95 percent that a significant amount of activity is present if the counting rate of a sample is not greater than that indicated above. Such a sample is reported to contain less than $(<)$ the detectable activity. Zero could not be reported because almost all samples contain at least a few micromicrocuries of activity owing to the amounts of potassium and radium daughters in most water.

The precision of a measurement lying below the detection limit is of little concern; by definition, the probability that the true value exceeds the reported figure is less than 50 percent. The precision of a measurement slightly above the detection limit may be taken as about 50 percent.

The accuracy of the method is controlled largely by the uniformity of the deposit on the planchet. However, accuracy probably is less affected by laboratory techniques than by the uncertainties arising from the counting statistics for most of the analyses.

\section{REGIONAL DISTRIBUTION CHARACTERISTICS}

To facilitate statistical interpretation of the data, the Conterminous United States was divided into the 10 geotectonic regions shown on plate 2 . The boundaries of these regions were based upon considerations of tectonics (National Research Council, 1944; Eardley, 1951), geology (Stose and Ljungstedt, 1933), physiography (Fenneman, 1946), and ground-water provinces (Meinzer, 1923, 1939). The grouping of areas having similar characteristics permitted delineation of regions in which the geology and hydrology are for the most part homogeneous and which are suitable units for deriving statistical data to describe the natural regional distribution of uranium and radium.

The regional characteristics of the waters were determined from only 509 of the 561 analyses available. Data from those samples having more than $3,000 \mathrm{ppm}$ (parts per million) dissolved solids were not used in the statistical computations because it is probable that 
such water may represent only local conditions or may have many characteristics that are not obtained from the host rock from which the samples were collected. Analyses of samples obtained from mining areas also were omitted because mining operations commonly alter the local geochemical regimen.

\section{INTERPRETATION OF DATA}

The uranium and radium concentrations in samples from those geotectonic regions where sufficient data were available to justify statistical treatment were plotted as histograms, on a logarithmic base, as shown in figures 1 to 6 . The class intervals for the statistical treatment were chosen in a manner to be consistent with the precision of the analyses (one significant figure at low concentrations), to cover the full range of concentrations with a reasonable number of intervals, and still be of reasonably uniform width. The reported concentrations and their probable ranges, together with the logarithmic class intervals are-

\begin{tabular}{|c|c|c|c|}
\hline \multicolumn{2}{|c|}{ Concentrations } & \multicolumn{2}{|l|}{ Class interval } \\
\hline Reported & Probable range & Logarithmic base & Width \\
\hline $\begin{array}{r}<0.1 \\
0.1 \\
0.2-\quad 0.3 \\
0.4-0.8 \\
0.9-1.8 \\
1.9-4.4 \\
4.5-10 \\
11-23 \\
24-54 \\
55-120 \\
130-290 \\
>290\end{array}$ & $\begin{array}{rr}0- & 0.069 \\
0.070- & .149 \\
.150- & .349 \\
.350- & .850 \\
.851- & 1.850 \\
1.851- & 4.450 \\
4.451- & 10.50 \\
10.51-23.49 \\
23.50-54.50 \\
54.51-125.0 \\
125.1 \quad-294.9 \\
>294.9\end{array}$ & 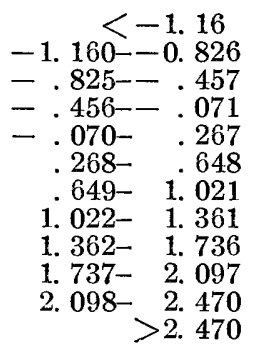 & $\begin{array}{r}\mathbf{0} 334 \\
.368 \\
.385 \\
.337 \\
.380 \\
.372 \\
.339 \\
.374 \\
.360 \\
.372 \\
\end{array}$ \\
\hline
\end{tabular}

Although the class intervals are not of exactly equal width, the maximum variation is less than \pm 8 percent from the average of 0.362 ; this is considered to be sufficiently good for the present needs.

Smoothed log-normal frequency distributions were calculated from the data and the curves representing these smoothed distributions are superimposed on the histograms for the appropriate regions. These frequency distributions and the log-normal curves were calculated as follows:

The cumulative frequencies of the concentrations were plotted on logarithmic-probability paper, and the best straight line through the points was determined by the method of least squares.

The mean value and standard deviation of the best-fit log-normal curve were determined from the straight line and substituted into the Gaussian equation.

The resulting equation was normalized to the scale of the histogram for the appropriate region, and the $634405-62-2$ curve representing the equation was plotted in superposition on the histogram.

The distribution of those samples lying below the detection limit was estimated from the best-fit lognormal curve and is shown as the dotted portion of the histogram. This technique makes possible an estimation of the distribution of those concentrations below the detection limit, provided that 50 percent or more of the samples are above the detection limit.

Although there is little reason to expect the universes from which the samples were taken to be distributed exactly according to a log-normal law, it can be seen from the figures that the approximation is sufficiently good that a log-normal distribution can be used as a model of each universe. To illustrate the differences between universe and sample distributions, a synthetic universe was sampled in a manner corresponding to the actual experiments. A universe having a log-normal distribution was constructed from a table of random numbers; 80 samples were then withdrawn at random from this universe and divided into 10 class-intervals. The histogram representing the 80 samples, together with the curve corresponding to the universe, are shown in figure 7. It will be observed that this fit is about the same as that observed in the plots representing the geotectonic regions; therefore, the proposed log-normal distributions are satisfactory models.

The antilog of the mean of the log-normal distribution curve corresponds to both the median and geometric mean of the concentrations in the model universe described by that curve. The antilog of the value lying two standard deviations above the mean of the lognormal distribution represents the concentration that would be exceeded by only about 2 percent of the members of the model universe. Therefore, a sample exceeding this value might well represent an anomaly, and this critical concentration is called the "anomaly threshold" for that universe. Values of the geometric mean and anomaly threshold of the model universe for each geotectonic region susceptible to statistical treatment are given in table 1 , together with the range and median for the sets of samples from each geotectonic region.

Uranium, as well as its daughter, radium, is in almost all rocks; hence, these elements probably are in all ground water as well as most surface water even though the amounts in many samples were below the detection limit. Samples of water having concentrations of radioelements greater than the anomaly threshold suggest local areas in which the rocks may be somewhat enriched in uranium. An exception to the above interpretation must be made for radium, because the method of analysis used in this study does not permit differentiating between radium-226 of the uranium series and 
DATA ON URANIUM AND RADIUM IN GROUND WATER IN UNITED STATES, 1954 TO 1957

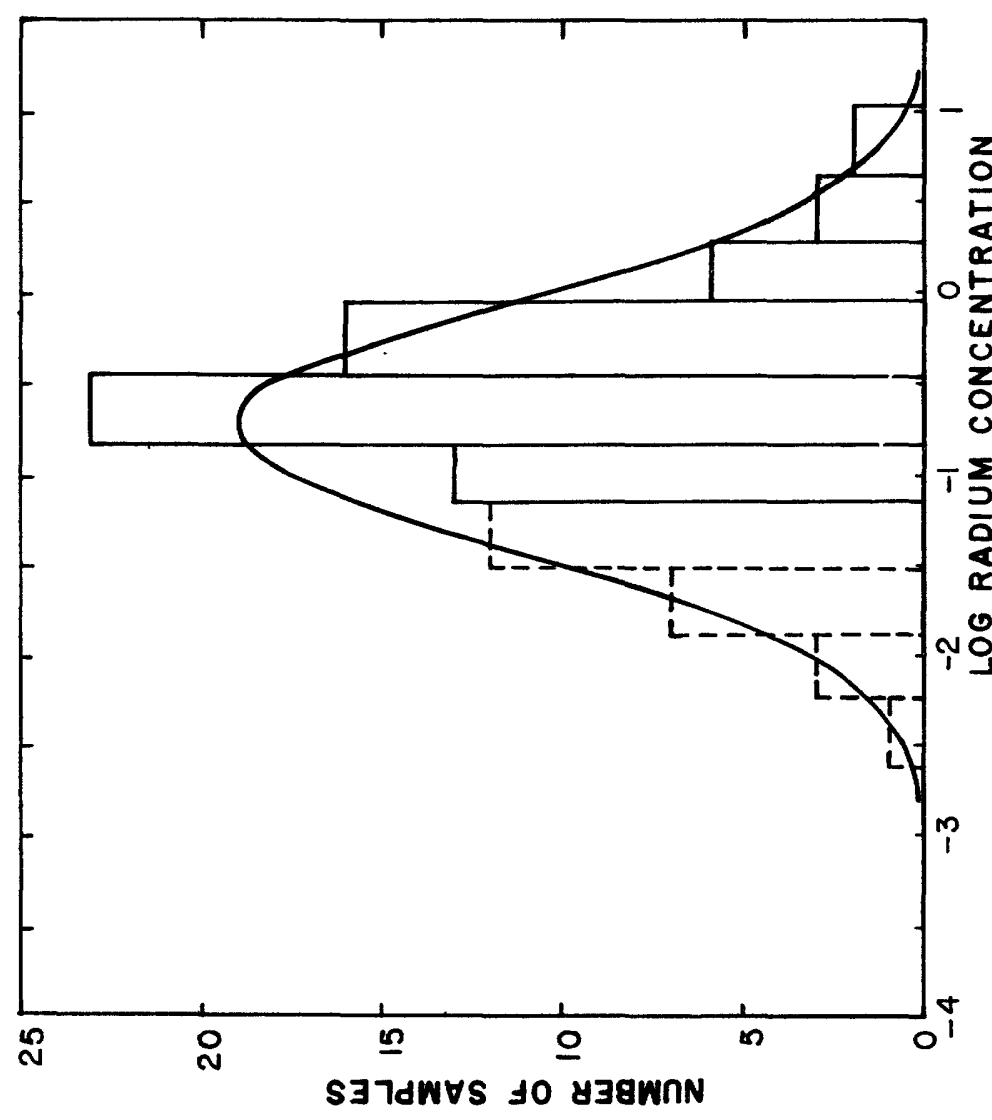

递 
INTERPRETATION OF DATA
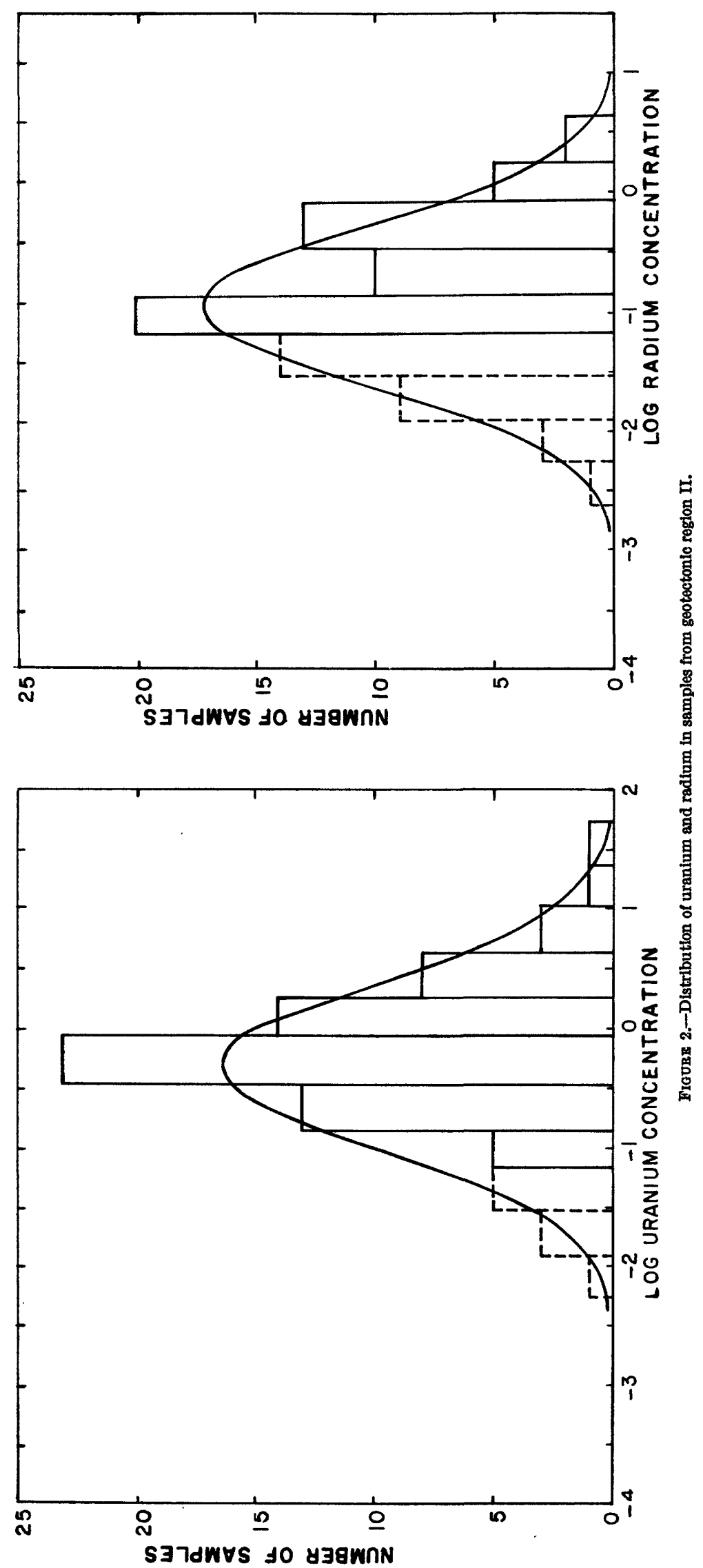
DATA ON URANIUM AND RADIUM IN GROUND WATER IN UNITED STATES, 1954 TO 1957
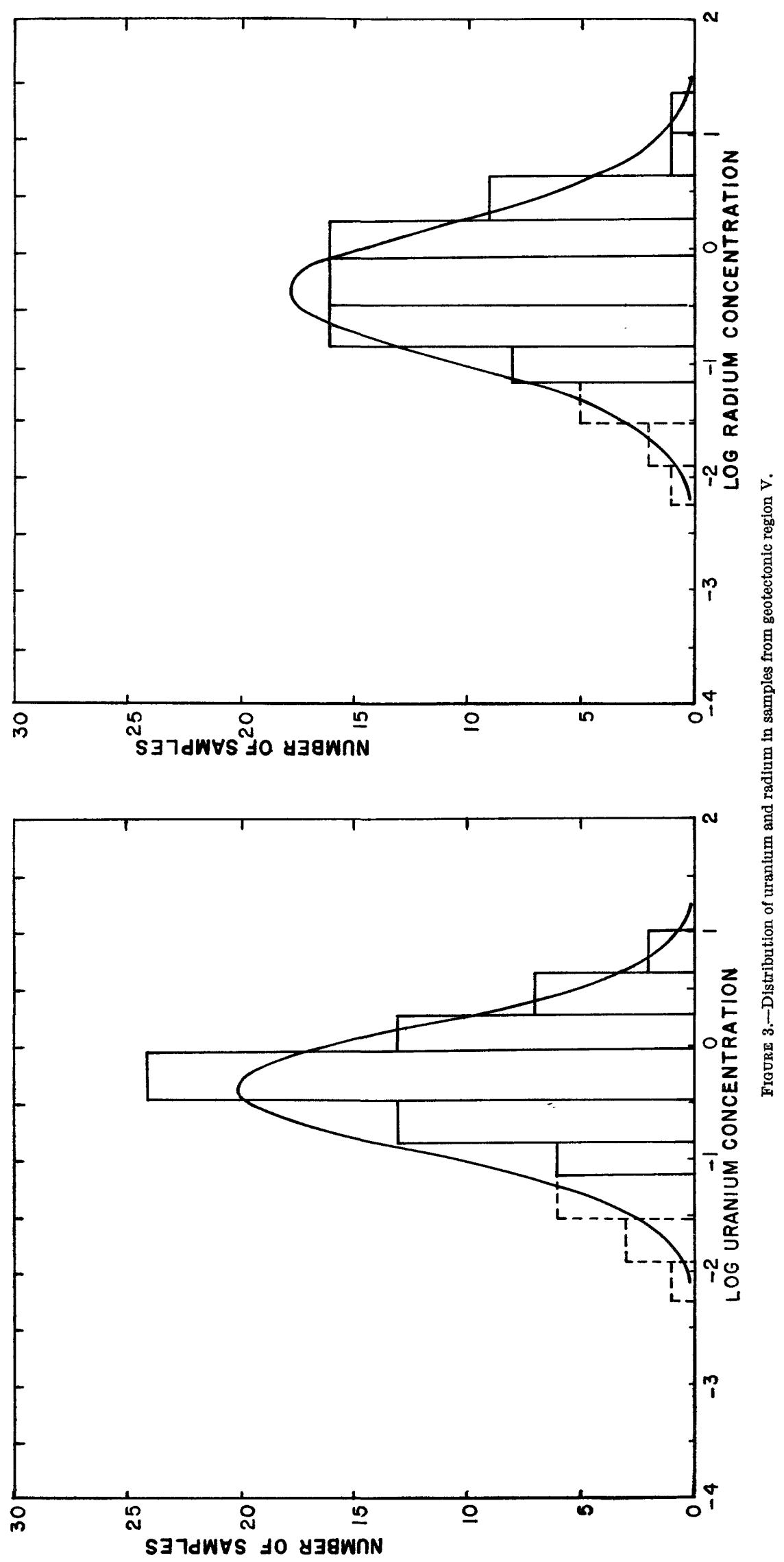

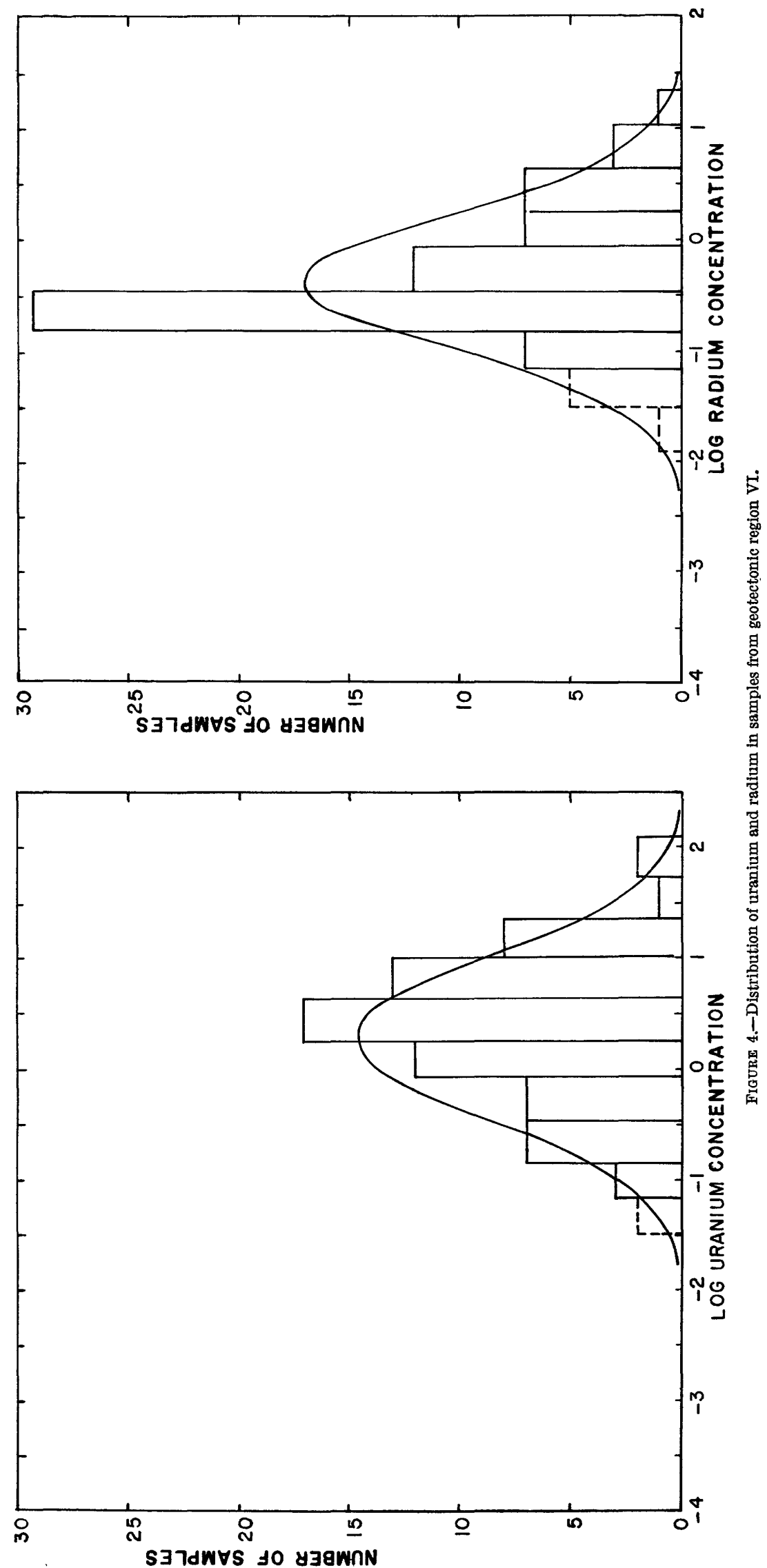


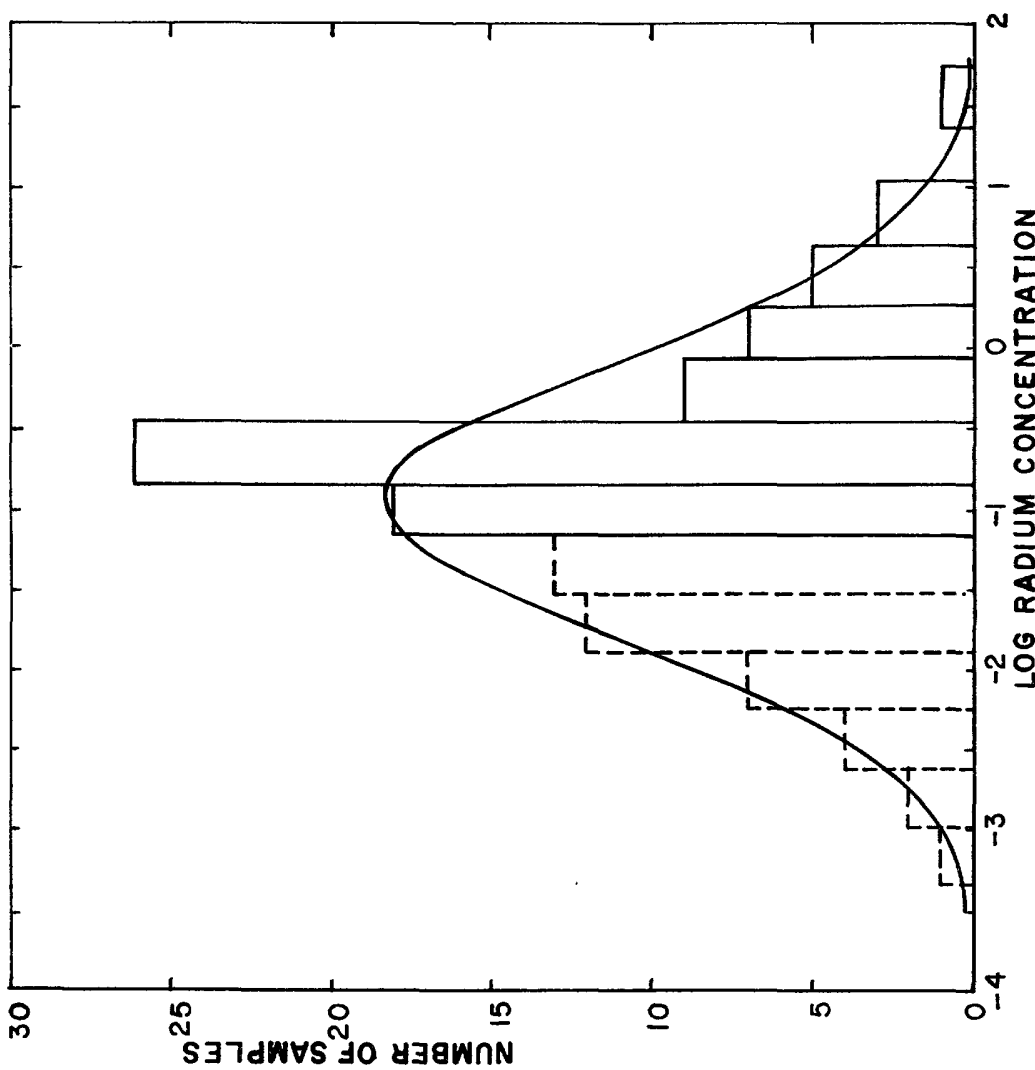

$N$ 

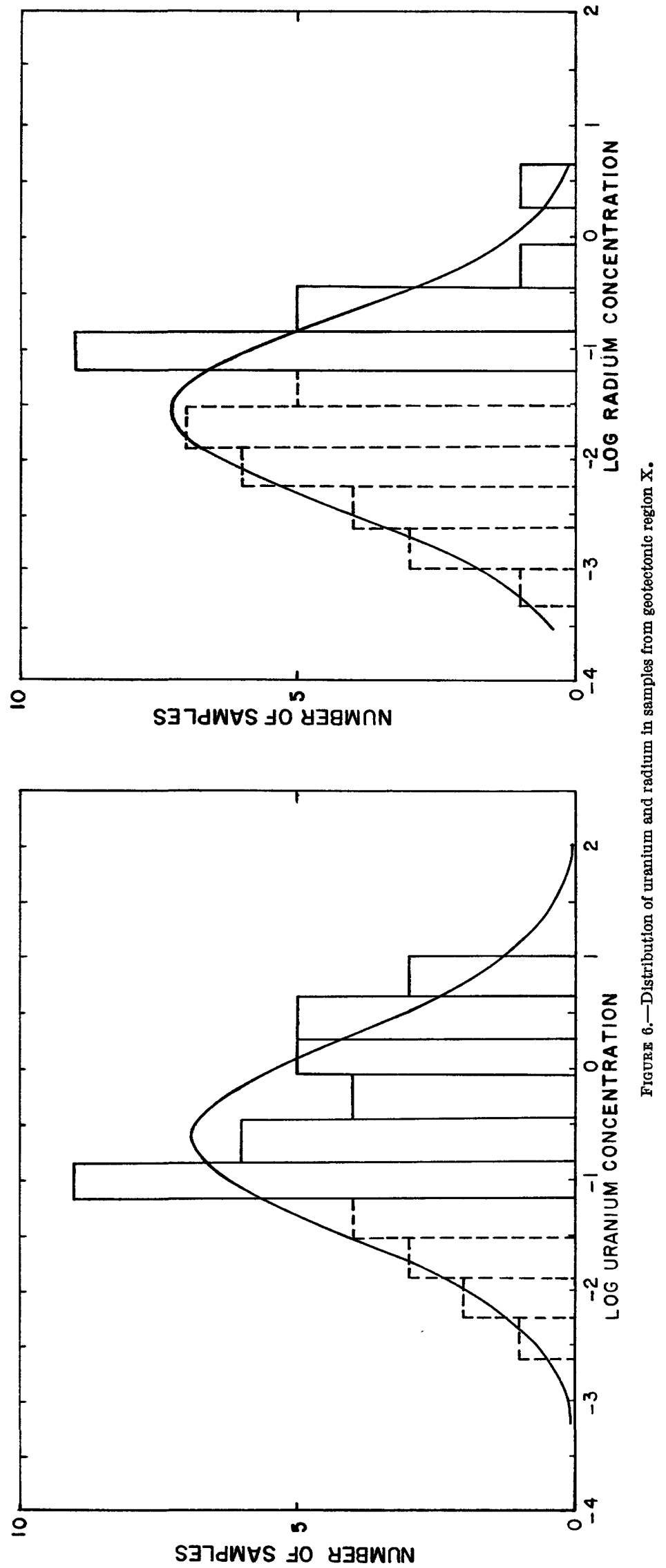
$\mathrm{T}_{\mathrm{ABLE}}$ 1.-Summation of data on concentrations of radioelements

\begin{tabular}{|c|c|c|c|c|c|c|c|c|c|c|c|c|c|}
\hline \multirow{2}{*}{$\begin{array}{l}\text { Geotec- } \\
\text { tonic } \\
\text { region }\end{array}$} & \multirow{2}{*}{$\begin{array}{c}\text { Number } \\
\text { of } \\
\text { samples }\end{array}$} & \multicolumn{4}{|c|}{ Uranium ( $\mu \mathrm{g}$ U per $\mathbf{l})$} & \multicolumn{2}{|c|}{$\begin{array}{l}\text { Ratio of uranium } \\
\text { to dissolved solids } \\
(\mu \mathrm{g} U \text { per } \mathrm{g} \text { DS) }\end{array}$} & \multicolumn{4}{|c|}{ Radium ( $\mu \mu \mathrm{c}$ Ra per 1) } & \multicolumn{2}{|c|}{$\begin{array}{l}\text { Ratio of radium } \\
\text { to dissolved solids } \\
\text { ( } \mu \mu \text { Ra per g DS) }\end{array}$} \\
\hline & & Range & Median & $\begin{array}{c}\text { Geometric } \\
\text { median }\end{array}$ & $\begin{array}{l}\text { Anomaly } \\
\text { threshold }\end{array}$ & Maximum & Median & Range & Median & $\begin{array}{c}\text { Geometric } \\
\text { median }\end{array}$ & $\begin{array}{l}\text { Anomaly } \\
\text { threshold }\end{array}$ & Maximum & Median \\
\hline $\begin{array}{l}\text { II } \\
\text { III } \\
\text { IV } \\
\text { V } \\
\text { VI } \\
\text { VII } \\
\text { VIII } \\
\text { IX } \\
\text { X }\end{array}$ & $\begin{array}{r}86 \\
77 \\
17 \\
7 \\
75 \\
72 \\
12 \\
108 \\
13 \\
42\end{array}$ & $\begin{array}{r}<0.1-15 \\
<.1-24 \\
<.1-\quad 1.5 \\
.2-\quad 4.3 \\
<.1-8.9 \\
<.1-120 \\
<.1-\quad 6 \\
<.1-37 \\
.1-6.1 \\
<.1-7.6\end{array}$ & $\begin{array}{r}0.2 \\
.5 \\
.5 \\
1.1 \\
.5 \\
2.2 \\
.3 \\
1.7 \\
.8 \\
.2\end{array}$ & $\begin{array}{r}0.2 \\
.5 \\
1.9 \\
1.9 \\
1.2 \\
.2\end{array}$ & $\begin{array}{c}3.3 \\
12 \\
58 \\
54 \\
12\end{array}$ & $\begin{array}{c}62 \\
70 \\
21 \\
10 \\
18 \\
319 \\
2.2 \\
63 \\
12 \\
25\end{array}$ & $\begin{array}{l}\text { 1. } 4 \\
\text { 4. } 0 \\
\text { 1. } 4 \\
\text { 7. } 0 \\
.9 \\
\text { 4. } 9 \\
\text { 1. } 2 \\
\text { 5. } 1 \\
2.4 \\
\text { 1. } 3\end{array}$ & $\begin{array}{l}<0.1-8.6 \\
<.1-3.3 \\
<.1-1.5 \\
<.1-2.6 \\
<.1-22 \\
<.1-11 \\
<.1-2.3 \\
<.1-29 \\
<.1-5.5 \\
<.1-2.5\end{array}$ & $\begin{array}{r}0.2 \\
.1 \\
.1 \\
.1 \\
.6 \\
.3 \\
1.0 \\
.1 \\
.1 \\
<.1\end{array}$ & \begin{tabular}{r}
0.2 \\
.1 \\
\hdashline .6 \\
.3 \\
.1 \\
$<.1$
\end{tabular} & $\begin{array}{r}7.0 \\
7.3 \\
5.9 \\
1.1\end{array}$ & $\begin{array}{r}174 \\
21 \\
4.1 \\
12 \\
96 \\
25 \\
13 \\
75 \\
25 \\
10\end{array}$ & $\begin{array}{r}1.0 \\
1.0 \\
.6 \\
.8 \\
1.0 \\
.90 \\
2.1 \\
.4 \\
.5 \\
.3\end{array}$ \\
\hline
\end{tabular}

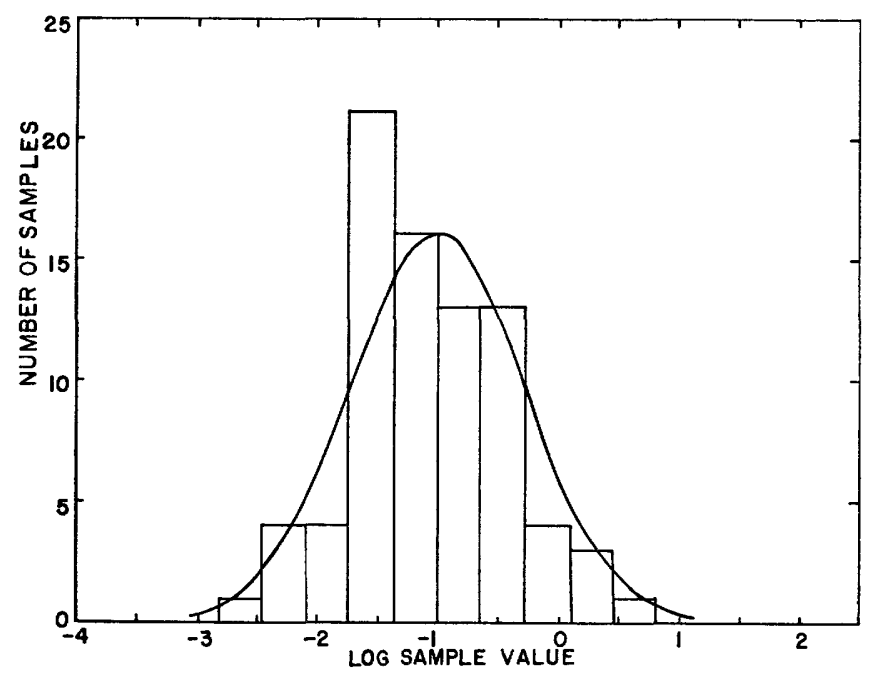

FIGURE 7.-Distribution of 80 samples from a synthetic log-normal universe, with true distribution curve.

radium-224 of the thorium series. Therefore, any sample containing anomalous amounts of radium that is mostly radium-224 would represent water that has had a history in rocks enriched in thorium. However, the geochemical cycles of uranium and thorium are sufficiently different in the lithosphere and hydrosphere so that most of the radium in the samples described in this report may be expected to be the daughter product of uranium.

The ratios of the concentrations of radioelements to that of the dissolved solids (U:DS) and (Ra:DS), expressed as micrograms of uranium per gram of dissolved solids and micromicrocuries of radium per gram of dissolved solids, respectively, are useful as indices for comparing samples of different dissolved-solids content on an equal basis. Differences in these ratios probably are controlled mainly by the abundances and solubilities of the radioelement-bearing minerals relative to the abundances and solubilities of minerals of the ordinary chemical constituents. The maximums and medians of these ratios for each geotectonic region are included in table 1.

In computing the medians of the U : DS and Ra:DS ratios, the uncertain values (that is, those representing samples in which the uranium or radium concentrations were below the detection limit of the analytical method) were included if they could not be greater than the median and were not included if they could lie on either side of the median.

In most geotectonic regions, a few samples of weakly mineralized water contained less uranium or radium than the anomaly threshold, but they had larger U:DS ratios than the maximum U:DS ratio of the anomalous samples. Therefore, even though the actual amounts of uranium and radium in these samples seemingly are low, the magnitude of the U:DS ratios may suggest areas that are locally enriched with uranium.

\section{GEOTECTONIC REGIONS}

\section{Region I. ATLANTIC AND GULF COASTAL PLaIN}

The coastal plains of the eastern and southern margins of the United States are underlain by marine and continental sediments of Mesozoic and Cenozoic age derived principally from older rocks of the Appalachian orogenic belt and the Central stable interior. The important aquifers in much of the area are beds of sand and gravel interbedded with clay and marl; but limestone is included in Texas, Georgia, South Carolina, and Florida, and material of glacial origin is included on Long Island and in the northern part of the Mississippi embayment.

The median concentration of uranium in this area $(0.2 \mathrm{ppb})$ is as small as that found in any region. Two samples contained quantities of uranium greater than the anomaly threshold $(3.3 \mathrm{ppb})$ suggested in table 1 . One sample (table 2: Texas 15), containing $15 \mathrm{ppb}$ uranium, was obtained from the Oakville sandstone and the other (table 2: Texas 16), containing $3.5 \mathrm{ppb}$ uranium, was from the Lagarto clay. Both formations 
are of Miocene age and are in an area where the Tertiary rocks contain much volcanic ash and uranium deposits. The volcanic material may be the source of the uranium ore deposits found in the area (Eargle and Snider, 1957, p. 30).

The U:DS ratio for the sample from the Oakville sandstone is $13 \mu \mathrm{g}$ per g solids and is the larger of the two samples. Six samples from the Atlantic and Gulf Coastal Plain (table 2: Alabama 11, New Jersey 4, New York 12, South Carolina, 3, Florida 1, Kentucky 11) had equivalent or larger $U$ :DS ratios and may be considered anomalous for this region.

Samples containing more radium than the anomaly threshold (3.8 $\mu \mu \mathrm{c}$ per l) were collected from an aquifer of Cretaceous limestone and clastic rocks (table 2: Texas 10) and from an Eocene marine sand (table 2: South Carolina 7). Both these samples were low in bicarbonate $\left(\mathrm{HCO}_{3}{ }^{-}\right.$less than 38 percent of the anions) and contained small amounts of uranium. None of the samples containing less than anomalous amounts of radium had $\mathrm{Ra}: \mathrm{DS}$ ratios greater than the South Carolina sample described above.

\section{REGION II. APPATACHUAN OROGENIC BETT}

This region has a structural history of related Paleozoic metamorphism, faulting, and folding. The rocks are predominantly granite, gneiss, and schist of Precambrian age and shale, sandstone, and limestone of Paleozoic age. Most of the rocks have been metamorphosed to some extent. Ground-water supplies in this area are commonly obtained from springs and shallow wells in rocks which transmit water through fractures. In the northern part of the region, material of glacial origin (Pleistocene) contains clastic aquifers of local importance. Elsewhere, small areas of sandstone and shale of Triassic age also may yield moderate supplies. Although this region does not have numerous exploitable deposits of uranium, it does include two geologic terranes that may be considered uraniferous. These are the marine black shales of Paleozoic (probably Devonian) age in the southern part of the area and the granites at White Mountain in New Hampshire (McKelvey, and others, 1955, p. 475, 514).

The occurrence of disseminated uranium in these terranes may be reflected by the somewhat greater radioactivity of water from this region as shown in table 1. One sample contained more uranium than the anomaly threshold (12 ppb). This sample, containing $24 \mathrm{ppb}$ uranium, was from shales of Triassic age, probably of fluviatile origin (table 2: North Carolina12).

Three samples had U:DS ratios exceeding that of the above sample (17 $\mu \mathrm{g}$ per $\mathrm{g}$ solids). Two of these samples were waters from New England granites (table 2: Maine 3 and Massachusetts 2) and the other was from a metasediment (table 2: Georgia 7). These data suggest that there are additional uraniferous areas in this region.

A sample from a granitic terrane in Maine had the only radium concentration (3.3 $3 \mu \mathrm{c}$ per l) greater than the anomaly threshold $(2.2 \mu \mu \mathrm{c}$ per 1$)$. The Ra:DS ratio for this sample, $21 \mu \mu \mathrm{c}$ per g solids, also was the maximum for this region.

\section{REGION III. APPaLAChIAN PLATEAUS}

This region is underlain by a thick sequence of clastic sediments and limestone of Paleozoic age, and includes many important coal beds. The principal sources of ground water are sandstones and limestone of Paleozoic age, but throughout considerable parts of the region the supplies obtained from those aquifers are meager or of poor quality. In many of the valleys large supplies are obtained from glacial outwash and other alluvial sands and gravels (Meinzer, 1923, p. 311).

Because this region is contiguous to the Appalachian Mountains to the east, and also contains uraniferous Paleozoic marine black shales, the radioelement characteristics of the ground water may be about the same as those of the Appalachian orogenic belt. However, too few samples have been collected in this region to enable statistical determination of an anomaly threshold. Using the criteria of the Appalachian orogenic belt, one sample from this region may be significant. A sample collected from a limestone terrane (table 2: Kentucky 8) had U:DS ratio of $21 \mu \mathrm{g}$ per g solids. No other radioelement characteristics were considered significant for samples collected in this area.

\section{REGION IV. CANADTAN SHEELD}

This region is the southern part of the Precambrian complex of intrusive and metamorphic rocks which has been stable since Precambrian time. Much of the area in the United States is covered with a mantle of glacial drift and outwash. Most of the ground-water supplies are obtained from the glacial deposits, and some of this material may contain thorium minerals or possibly some heavy insoluble uraniferous minerals, concentrated as placers. However, the logical host rock for uranium minerals in this region (the Precambrian bedrock) is covered with glacial debris. Thus, ground water tributary to the glacial overburden from this bedrock may carry radioelements that reflect the history that the water has had in the bedrock.

Too few samples were collected in this region for reliable statistical interpretation. However, if the trend of values shown in table 1, especially those for uranium, can be sustained by additional sampling, ground water in this region normally may have a high radioelement content. 
REGION V. FASTERN STABLE REGION

The central stable Interior in the United States is that part of the North American craton coextensive with the Canadian shield and is overlain by a sequence of sedimentary rocks of Paleozoic age. For this study it has been subdivided into two regions in order to treat separately the eastern part with its partial cover of glacial sediments and the western part, most of which has a thick cover of important water-bearing sediments of post-Paleozoic age in addition to the other sedimentary rocks of Paleozoic age. Most water supplies in the eastern stable region are obtained from glacial drift and outwash; however, other important sources of supply are the sandstones and limestones of Paleozoic age and, in the northwestern part of the region, a sandstone of Cretaceous age.

Samples containing more uranium than the anomaly threshold (5.3 ppb) were obtained from a Precambrian quartzite (table 2: Minnesota 10) and a sandstone of Cretaceous age (table 2: Iowa 4). The U:DS ratios for these samples were 4.7, and $4.1 \mu \mathrm{g}$ per $\mathrm{g}$ solids, respectively. Two other samples (table 2: Kentucky 9 and Michigan 6) from this area had concentration factors greater than the maximum factor mentioned above (4.7 $\mu \mathrm{g}$ per g solids) and may indicate other areas having uranium mineralization above background.

The second greatest range of radium content was found in samples from this area, and the anomaly threshold for radium is also second highest $(7.0 \mu \mu \mathrm{c}$ per 1). The largest radium concentration (22 $\mu \mu \mathrm{c}$ per l) was found in a sample collected from a limestone of Ordovician age, (table 2: Kentucky 4) and the Ra:DS ratio (96 $\mu \mu \mathrm{c}$ per g solids) also was the maximum for the region. One other sample (table 2: Kentucky 1) in this region contained an anomalous amount of radium (9.8 $\mu \mu \mathrm{c}$ per 1$)$.

\section{REGION VI. WESTERN STABLE REGION}

This region is that part of the central stable interior lying west of the divide between the Missouri and Mississippi Rivers. Principal aquifers in the region are Tertiary sand and gravel and Cretaceous sandstone of marine or near-shore origin. Most of the postPaleozoic sediments were derived from the granitic and metamorphic rocks of the Rocky Mountain orogenic belt. Many of the Tertiary rocks contain much volcanic ash. Samples of ground water from this region contained the largest amounts of uranium and had the second highest anomaly threshold for uranium. These data are compatible with the lithology of the aquifers; volcanic ash and the large amount of material weathered from granitic rocks probably are responsible for the high uranium content.
Although the anomaly threshold for uranium in this region (48 $\mu \mathrm{g}$ per 1) seemingly is disproportionately high, there is no justification for treating this region diffierently from the others. In view of the relatively high median concentration and the lack of significant skewness of the distribution curve, a high anomaly threshold appears justified. Further sampling may indicate that a lower anomaly threshold applies to small areas within this region.

The largest uranium concentration $(120 \mu \mathrm{g}$ per $\mathrm{l})$ was found in a sample from the Rush Springs sandstone of Permian age at Cement, Okla. (table 2: Oklahoma 9). The Rush Springs is a reddish sandstone of littoral origin which crops out over a large area in central Oklahoma. This sample also had the largest U:DS ratio (319 $\mu \mathrm{g}$ per $\mathrm{g}$ solids) found for this region. Asphaltic and other bituminous sandstone, mostly of Permian age, occurring elsewhere in Oklahoma are known to be abnormally radioactive. It has been suggested that some of the locally bleached and altered Permian red beds overlying the Cement oil field should be examined for radioelement ore bodies (Branson and others, 1955, p. 19).

About 5 miles soutbeast of the sampling site at Cement another sample was collected from the Rush Springs sandstone (table 2: Oklahoma 10). It contained only $2.2 \mu \mathrm{g}$ per 1 of uranium and had a U:DS ratio of $4.9 \mu \mathrm{g}$ per $\mathrm{g}$ solids. More geochemical work probably will disclose that uraniferous material occurs only locally in the area underlain by the Rush Springs sandstone.

A sample from alluvium of Pleistocene age (table 2: Kansas 6) was the only other sample having a uranium content above the anomaly threshold. The uranium content was $74 \mu \mathrm{g}$ per $\mathrm{l}$ and the U:DS ratio was $31 \mu \mathrm{g}$ per $g$ solids. The uranium in these sediments may represent a concentration of minerals derived by the reworking of relatively uraniferous Tertiary rocks during Pleistocene time.

Three samples (table 2: Colorado 13, Kansas 15, and New Mexico 1) contained amounts of radium larger than the anomaly threshold (7.3 $\mu \mu \mathrm{c}$ per 1$)$ suggested in table 1, but the uranium content of these samples was relatively low. Thus, the anomalous radium concentrations may indicate areas for further investigation for geologic accumulations of radioelements in addition to those based on the uranium data. The maximum Ra:DS ratio of these samples was $6.4 \mu \mu \mathrm{c}$ per g solids. Using this factor as a criterion, four other samples (table 2: Colorado 16, Kansas 7, and Oklahoma 3 and 11) having radium concentration factors greater than 6.4, also may suggest sites where more work should be done to determine the cause of the abnormal radioactivity. 
REGION VH. OZARK-OUACHITA STSTEM

Two minor tectonic elements make up this region, but, because both are deformed Paleozoic rocks, they are considered as one unit in this paper. The Ozark dome to the north is formed of beds of limestone and dolomite dipping gently off the Precambrian granitic core of the St. Francis Mountains. Southward the proportion of clastics increases, shale and sandstone predominating in the Ouachita Mountains.

Although there are insufficient samples for statistical analysis, seemingly the uranium content of the ground water of this region will be among the lowest in the country.

The high radioactivity of the numerous hot springs in the southern part of the Ouachita Mountains is well known and has been studied by many investigators. Although the radioactivity of the thermal waters is caused primarily by radon gas, many of the spring waters contain large amounts of radium. The medianradium concentration $(1.0 \mu \mu \mathrm{c}$ per l) and median $\mathrm{Ra}: \mathrm{DS}$ ratio (2.1 $\mu \mu \mathrm{c}$ per 1 solids) for this region are the highest for all the regions.

\section{REGION VIII. ROCKY MOUNTAIN OROGENIC BELT}

This region for the most part is the area affected by the Laramide orogeny at the end of the Cretaceous and in early Tertiary time. Subsequent uplift and erosion exposed both igneous and sedimentary rocks of Precambrian age in the eastern central part of the region. Most of the area is underlain by folded and faulted sedimentary rocks of Paleozoic and Mesozoic age, granitic rocks of Mesozoic age, and sediments deposited in Tertiary basins. Many of the sedimentary rocks of Cretaceous and Tertiary age contain considerable amounts of volcanic ash. Important exploitable radioactive mineral deposits have been found in Precambrian igneous rocks and in the sedimentary rocks of Mesozoic and Tertiary age. Abundant ground-water supplies are obtained from Tertiary strata and many of the sandstones of Cretaceous age.

The anomaly threshold is highest and the medianuranium concentration and the median U:DS ratio are both second highest for the geotectonic regions of the United States. Excepting mine waters, two samples contained more uranium than the anomaly threshold (54 $\mu \mathrm{g}$ per l). Both were collected from granitic rocks of probable Jurassic or Cretaceous age in southeastern California. These samples (table 2: California 28 and 32 ) contained 32 and $37 \mu \mathrm{g}$ per 1 and the $\mathrm{U}: \mathrm{DS}$ ratios were 15 and $51 \mu \mathrm{g}$ per g solids, respectively. One sample (table 2: South Dakota 7) collected in a uranium mine contained $960 \mu \mathrm{g}$ per 1 of uranium and had a U:DS ratio of $619 \mu \mathrm{g}$ per $\mathrm{g}$ solids. The analytical results of this sample were not included in the statistical analysis of this region because samples collected during mining operations may be contaminated and not representative of natural conditions.

A sample collected from an industrial well on the uranium property of the Lucky Mc. Uranium Co. (table 2: Wyoming 13) contained 2,100 ppb uranium and had a $\mathrm{U}: \mathrm{DS}$ ratio of $1,533 \mu \mathrm{g}$ per $\mathrm{g}$ solids. This sample was also excluded from the statistical analysis. These mine water samples were the only samples of fresh water that had U:DS ratios greater than $51 \mu \mathrm{g}$ per $g$ solids.

The radium anomaly threshold $(5.9 \mu \mu \mathrm{c}$ per 1$)$ was exceeded, excepting the above mine waters, in only one sample (table 2: New Mexico 24) from this region. The $\mathrm{Ra}$ :DS ratio of the above sample was $75 \mu \mu \mathrm{c}$ per g solids and is the maximum for the region. The sample was obtained from a thermal spring, and such waters commonly have large amounts of radium and high radiumconcentration factors.

\section{REGION IX. COLORADO PLATFAU}

The Colorado Plateau is a stable region within the area that was structurally deformed by the Laramide orogeny. The basement, primarily a Precambrian crystalline complex, is overlain by rocks of Paleozoic and Mesozoic age which correlate with most of the rocks of the same age in the western stable region. The postLaramide igneous activity that was widespread throughout the Rocky Mountain orogenic belt was common in this region also. Ground-water supplies on the plateau are meager, but supplies adequate for most needs locally are obtained from sandstones of Mesozoic age and gravel of Quaternary age.

This region is the chief uranium province of the United States, both areally and quantitatively. It was not possible before preparation of this report to collect sufficient samples of ground water for statistical treatment from sources known to be unassociated with uranium deposits. Most ground-water supplies in the area are developed for mining and milling operations; hence, the wells are drilled into, or adjacent to, ore bodies.

Because of the small number of samples, statistical interpretation of the data is not practical. The values given for region IX in table 1 seemingly are too low for an uraniferous province; however, this is to be expected because of the selective sampling which discriminated against known uraniferous areas in the region. The statistical results from the western stable region might tentatively be used to evaluate this region, for these two regions were coextensive before the Laramide orogeny. If the anomaly threshold for region VI is used, none of the samples of ground water collected on the Colorado Plateau had radioelement contents that suggested areas that have much radioelement mineralization. However, a sample obtained from the Colorado River at 
Dewey Bridge, near Cisco, Utah, had a Ra:DS ratio of $25 \mu \mu \mathrm{c}$ per g solids. This factor is much greater than the significant radium concentration factor of region VI (6.4 $\mu \mu \mathrm{c}$ per g solids). The seemingly disproportionate amount of radium in the river water is attributed to uranium milling operations located along several of the tributaries to the Colorado River.

Many of the water samples collected in this region were obtained from rocks which elsewhere do contain important uranium ore bodies in the oxidized zone. It should be emphasized that the samples were collected only from presumably barren areas, because samples of ground water from known ore bodies were specifically omitted from the sampling program.

\section{REGION $X$. PACIFIC OROGENIC BELT}

This region is one of complex tectonic history involving several orogenic movements of different ages, some so recent that strata of Pleistocene age, and even of Recent age, have been deformed. Cenozoic sedimentary and volcanic rocks are the most common aquifers in this region, and much of the area is underlain by material resulting from intense volcanic activity that bega 1 in Permian time and has continued intermittently until Recent time. Crystalline rocks of the batholithic intrusions emplaced in Mesozoic time have been uncovered in some of the mountain ranges existing today. Ground-water supplies are obtained principally from late Tertiary and Quaternary valley fill, but where these deposits are absent, satisfactory supplies often are obtained locally from sedimentary rocks and lava flows of Tertiary age.

The radiochemical data shown in table 1 indicate that the aquifer material of this region is not particularly uraniferous. According to the analyses, none of the samples contained more uranium than the anomaly threshold $(12 \mu \mathrm{g}$ per $\mathrm{l})$. Therefore, none of the U:DS ratios are considered significant.

The median concentration, median $\mathrm{Ra}: \mathrm{DS}$ ratio, and anomaly threshold shown in table 1 for radium in this region are the smallest values found in the conterminous United States. A sample collected from sediments of Tertiary age (table $2:$ Nevada 6 ) that probably contain interbedded volcanic rocks, exceeded the radium anomaly threshold for this region. This sample containing the largest radium concentration and having the largest $\mathrm{Ra}: \mathrm{DS}$ ratio may be indicative of the radioelement content of the volcanic rocks.

\section{LITERATURE CITED}

Barker, F. B., and Thatcher, L. L., 1957, Modified determination of radium in water: Anal. Chemistry, v. 29, p. 1573-1575.

Branson, C. C., Burwell, A. L., and Chase, G. C., 1955, Uranium in Oklahoma: Oklahoma Geol. Survey Mineral Rept. 27.

Eardley, A. J., 1951, Structural Geology of North America: New York, Harper \& Bros., 624 p., 16 pls., 343 figs.
Eargle, D. H., and Snyder, J. H., 1957, A preliminary report on the stratigraphy of the uranium-bearing rocks of the Karnes County are, south-central Texas: Univ. Texas Bur. Econ. Geology, Rept. Inv. 30, 30 p.

Fenneman, N. M., 1946, Physical division of the United States, U.S. Geol. Survey.

Friedlander, Gerhart, and Kennedy, J. W., 1955, Nuclear and radiochemistry: New York, John Wiley \& Sons, $468 \mathrm{p}$.

McKelvey, V. E., Everhart, D. L., and Garrels, R. M., 1955, Origin of uranium deposits: Econ. Geology 50th anniversary volume, pt. 1, p. 464-533.

Meinzer, O. E., 1923, The occurrence of ground water in the United States, with a discussion of principles: U.S. Geol. Survey Water-Supply Paper 489, 321 p., 31 pls., 110 figs.

1939, Ground water in the United States, a summary: U.S. Geol. Survey Water-Supply Paper 836-D, p. 157-232, pl. 15, figs. 11-41.

National Research Council Committee on Tectonics, 1944, Tectonic map of the United States: Tulsa, Okla., Am. Assoc. of Petroleum Geologists.

Rainwater, F. H., and Thatcher, L. L., 1960, Methods of collection and analysis of water samples: U.S. Geol. Survey Water-Supply Paper 1454, 301 p., 17 figs.

Scott, R. C., and Barker, F. B., 1958, Radium and uranium in ground water of the United States, in Proceedings of the second United Nations international conference on the peaceful uses of atomic energy: New York, United Nations, v. 2, p. 153-157.

Stose, G. W., assisted by Ljungstedt, O. A., 1933, Geologic map of the United States: U.S. Geol. Survey.

Thatcher, L. L., and Barker, F. B., 1957, Determination of uranium in natural waters: Anal. Chemistry, v. 29, p. 1575-1578.

\section{GEOLOGIC, HYDROLOGIC, AND CHEMICAL DATA}

Data for each State are presented in table 2. This table is divided into two parts; one on each of facing pages. One part, a record of sampling sites, contains brief descriptions of the location and the geologic and hydrologic characteristics of sources of the samples; the facing part, a compilation of chemical data, presents the results of the chemical and radiochemical analyses. The table is also subdivided according to the States, which are listed alphabetically.

Information to be found under the headings of the tables is explained below.

No. on plate 1.-All sampling sites are shown on the accompanying map, plate 1 ; these sites were numbered serially in a general north-south direction for each State, beginning at the northwest corner of the State. The number in the table corresponds with the location number on the map. These columns are the same in the two parts of the table.

Location-Locations are shown by county and by proximity to towns.

Well or spring number or name. - Well or spring number used by Ground Water Branch district offices is given wherever possible, as well as local names if they exist. Owners' well and spring numbers are shown only when no other means of identification exists. 
Use.--Letter symbols for use are-

D Domestic, a source that furnishes drinking and culinary water for one or several. households.

I Irrigation.

Ind Industrial.

M Municipal.

N Not used.

Obs Observation well.

Pf Public facility, a source available to segments of the general public other than municipal supply. These facilities include such places as hospitals, military bases, and public parks.

\section{S Stock.}

Yield.- The discharge obtained by pumping or the unrestricted flow from artesian wells or springs is given. Letters " $\mathrm{r}$ " and " $\mathrm{e}$ " are used to indicate reported and estimated discharges, respectively.

Well characteristics. - The total depth of the well and the diameter of the casing are reported as obtained from available records. The water levels reported are the latest known measurements made before the collection of the sample. The water levels are shown as feet above $(+)$ or below $(-)$ land-surface datum (LSD).

Water-bearing formation.-The known or most probable source of the water is shown by formation name, age, and geologic terrane. Most of these data were obtained from Ground Water Branch district personnel who collected the samples and from the literature. The terranes are the authors' system for classifying many lithologic units into a few categories of the same general geologic and geochemical characteristics in order to facilitate the comparison of large groups of samples.

Igneous rocks are divided into two classes, volcanic and plutonic, each of which is further subdivided into silicic, intermediate, and basic. Metamorphic terranes are not common aquifers and few were sampled; thus, only the classes metaplutonic, metavolcanic, and metasedimentary are used. Sedimentary terranes are given a binomial classification; the first term indicates depositional environment, and the second, the lithologic category. For sedimentary terranes commonly described as specific types of unconsolidated material, the terrane types of the consolidated equivalents are shown. For the many samples obtained from sources yielding water thought to have originated about equally from two or more terranes, all the terranes are indicated. However, if a sample represents water that has had most of its history in one geologic terrane, even though other terranes are involved, then the terrane which has had the predominant geochemical influence on the water is the only one shown.

Geologic ages are indicated by the following symbols:

$\begin{aligned} \text { Q } & \text { Quaternary } \\ \text { Qr } & \text { Recent } \\ \text { Qp } & \text { Pleistocene } \\ \text { T } & \text { Tertiary } \\ \text { Tp } & \text { Pliocene } \\ \text { Tm } & \text { Miocene } \\ \text { To } & \text { Oligocene } \\ \text { Te } & \text { Eocene } \\ \text { Tpe } & \text { Paleocene } \\ \text { K } & \text { Cretaceous } \\ \text { J } & \text { Jurassic }\end{aligned}$

$\begin{aligned} \text { K } & \text { Triassic } \\ \text { Pal } & \text { Paleozoic } \\ \text { P } & \text { Permian } \\ \text { C } & \text { Carboniferous } \\ P & \text { Pennsylvanian } \\ \text { M } & \text { Mississippian } \\ \text { D } & \text { Devonian } \\ \text { S } & \text { Silurian } \\ \text { O } & \text { Ordovician } \\ € & \text { Cambrian } \\ \text { p€ } & \text { Precambrian }\end{aligned}$

Probable source of water.-The history of the water before entering the terrane indicated is given. The hydrology of the areas from which many of the samples were collected is not known in detail; hence, many of the data in this column are conjectural.

Temperature.-Temperature was measured at the time samples were collected. Where water passed through tanks or long pipelines, attempts were made to obtain true temperature of the water in the aquifer by permitting sufficient amounts of water to flush out stored water before measurements were made.

Date of collection.- The date on which the sample was taken.

Chemical constituents and physical properties.-These items are, for the most part, self-explanatory. Unless otherwise noted, the concentrations may be taken to represent rather closely the conditions in the aquifer. The main exceptions are aluminum, iron, and manganese, which hydrolize readily. For these constituents, footnotes indicate the interpretation that must be applied. The $\mathrm{pH}$, an indication of hydrogen-ion activity, is also affected by hydrolytic reactions and may, therefore, change between collection and analysis. It is difficult, however, to predict the magnitude and direction of changes in $\mathrm{pH}$ so that it should be taken only as a general indication of conditions in the aquifer.

The beta-gamma activities and radium concentrations are expressed in micromicrocuries per liter ( $\mu \mu \mathrm{c}$ per 1). One micromicrocurie is the quantity of a radioactive substance that undergoes 2.22 disintegrations per minute. Uranium concentrations are reported as micrograms per liter ( $\mu \mathrm{g}$ per l). This is nearly equivalent to parts per billion, except when the density of the sample differs greatly from that for pure water.

Remarks-Relevant information not shown under any of the preceding headings is included in this column. 
DATA ON URANIUM AND RADIOM IN GROUND WATER IN UNITED STATES, 1954 TO 1957

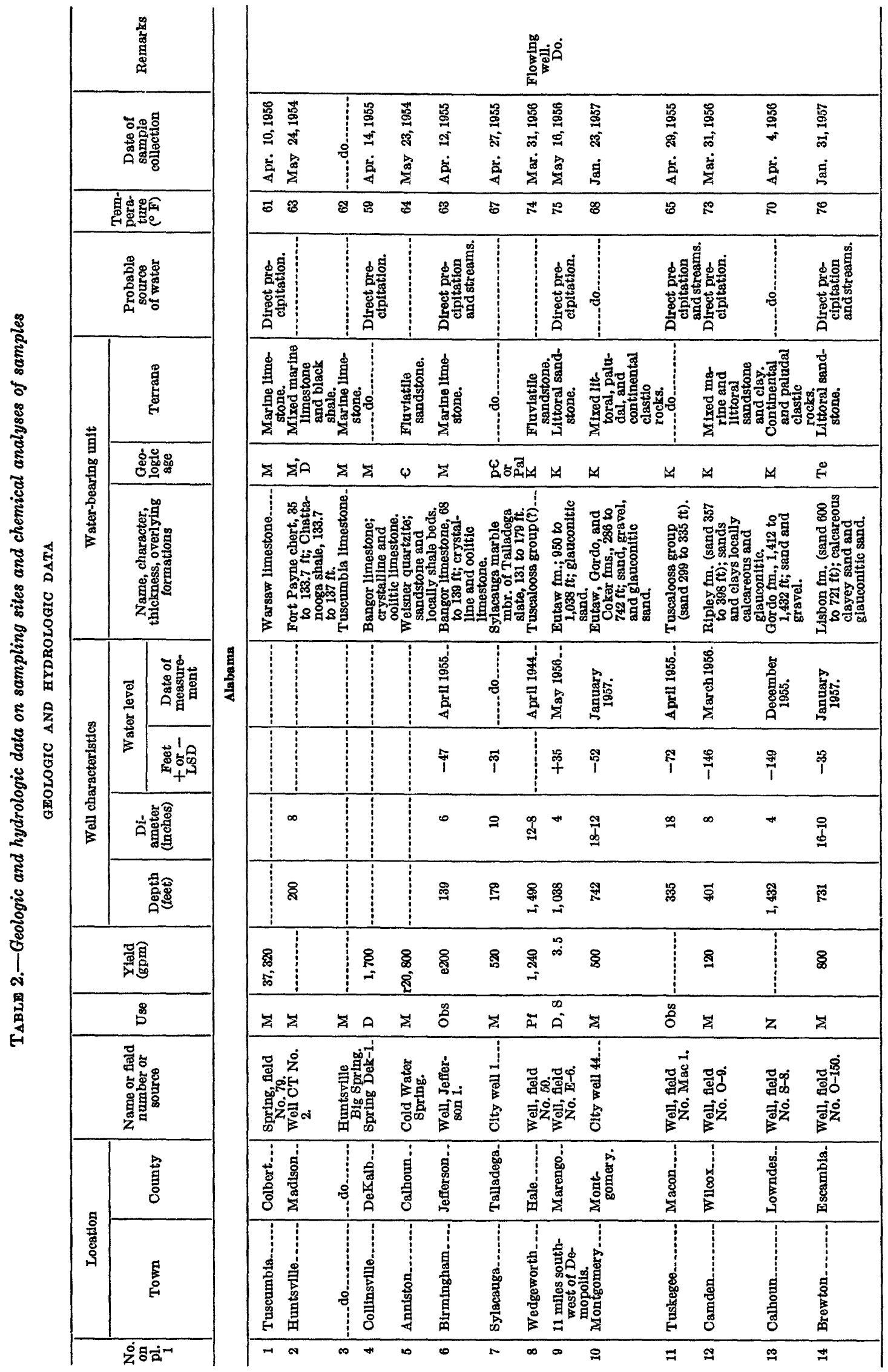


GEOLOGIC, HYDROLOGIC, AND CHEMICAL DATA

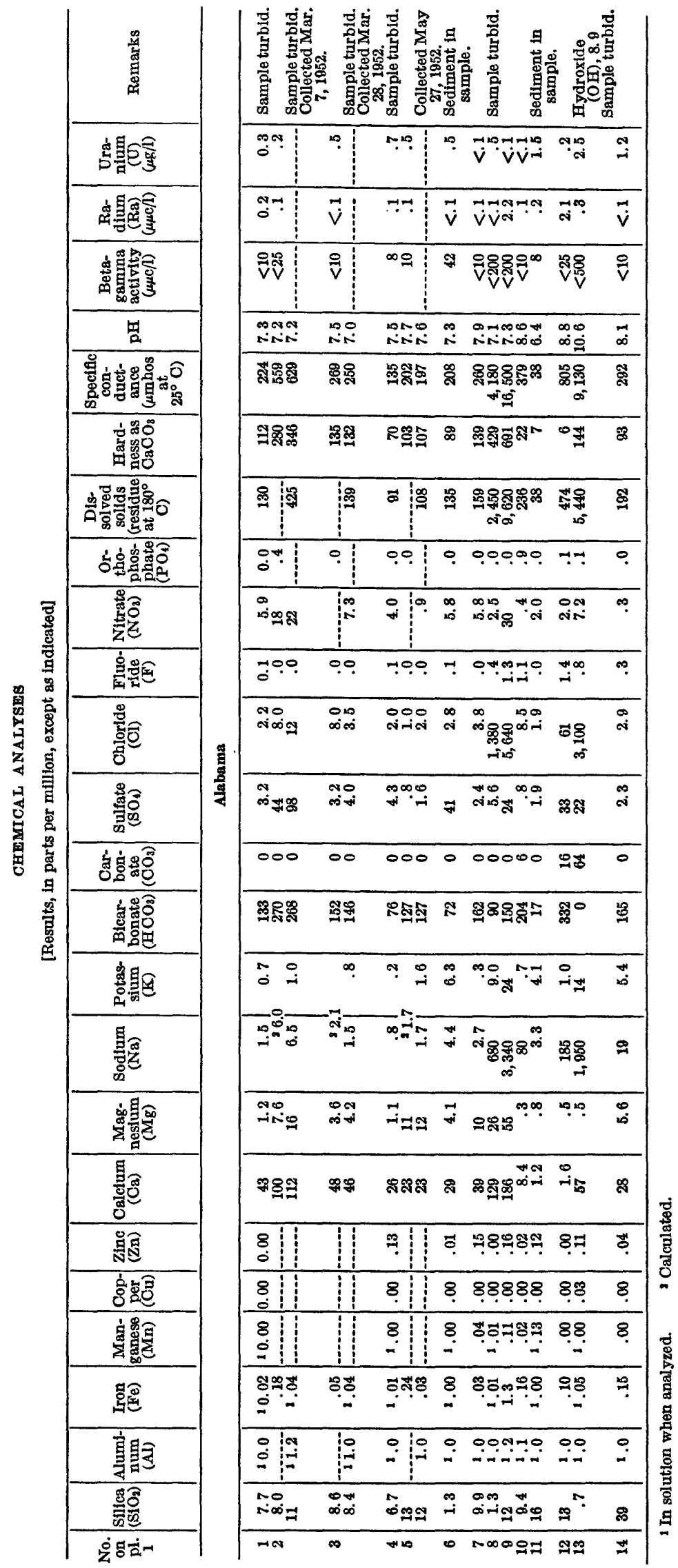




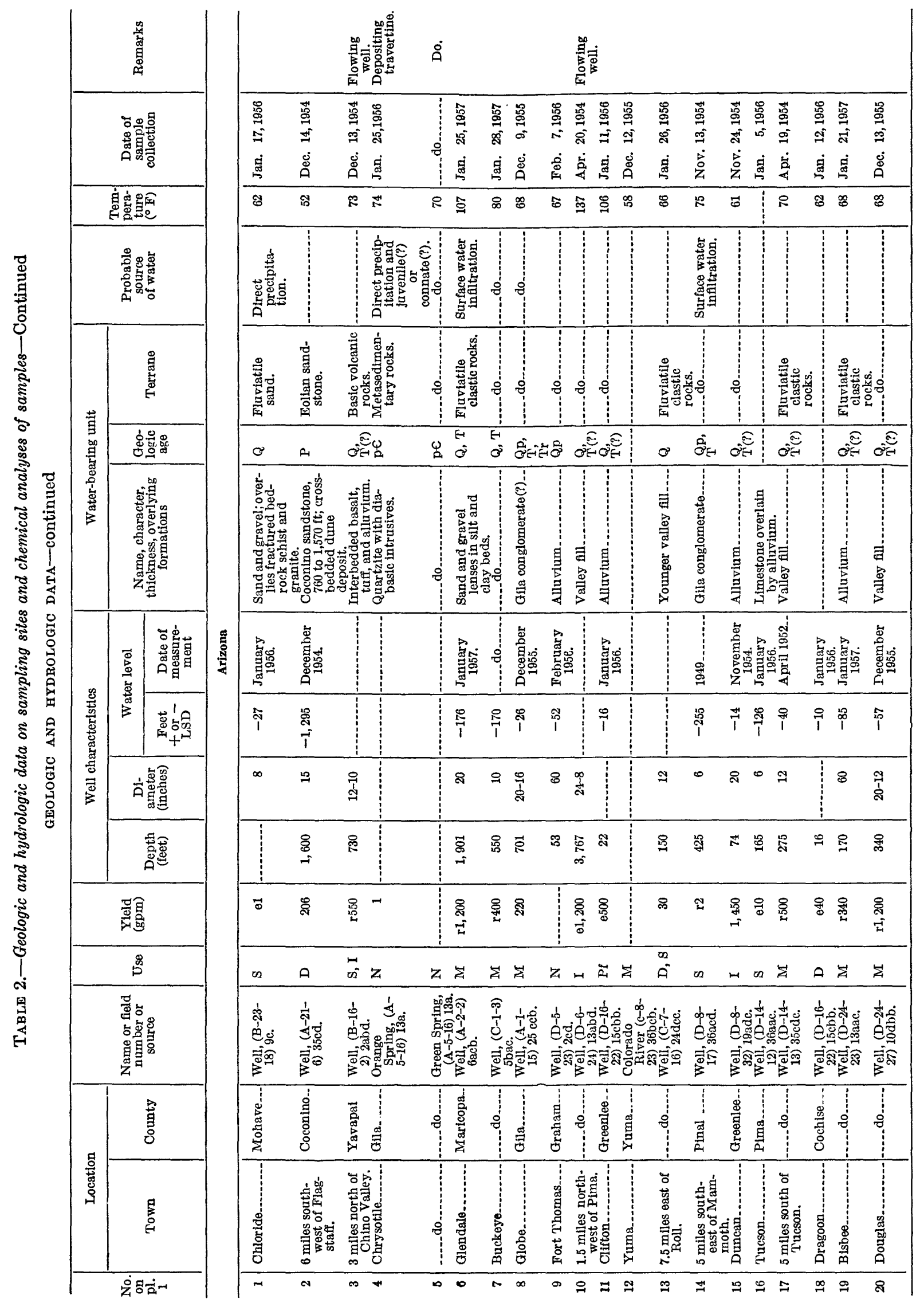


GEOLOGIC, HYDJOLOGIC, AND CHEMICAL DATA

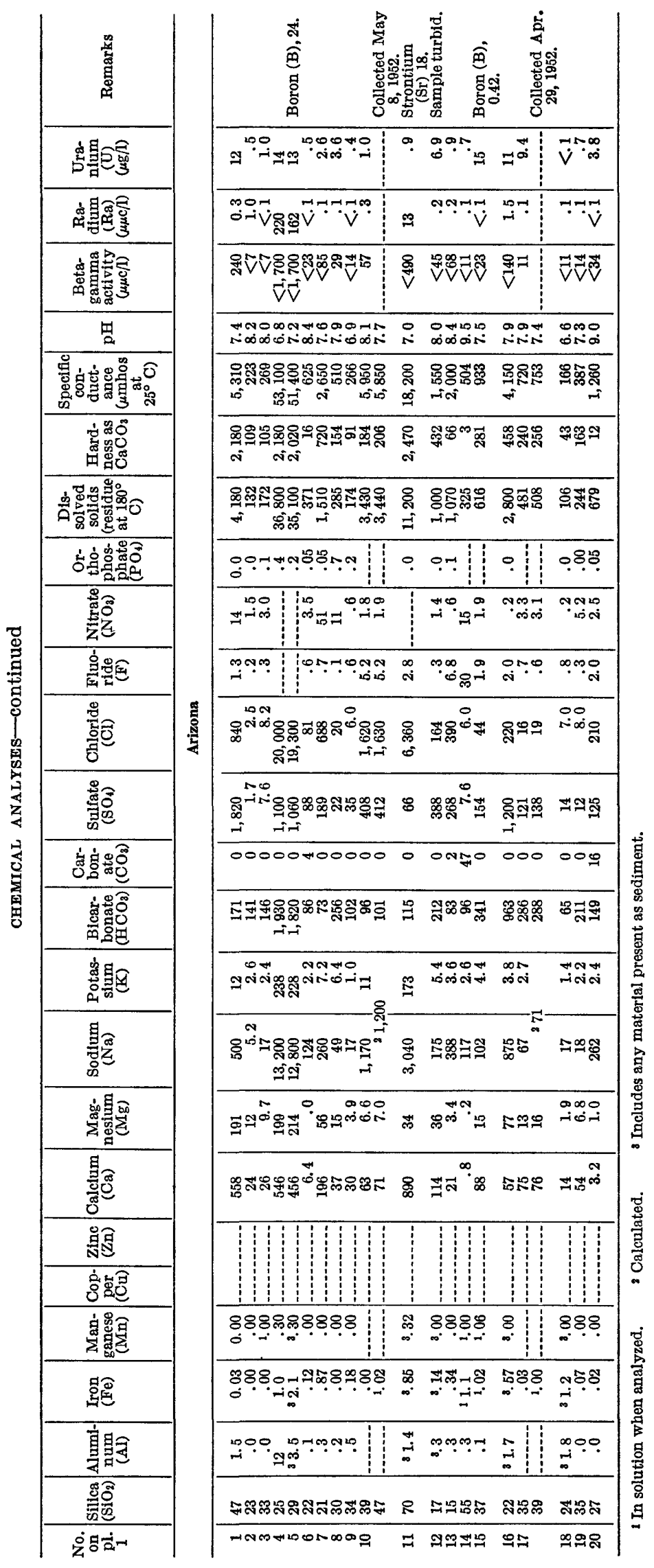




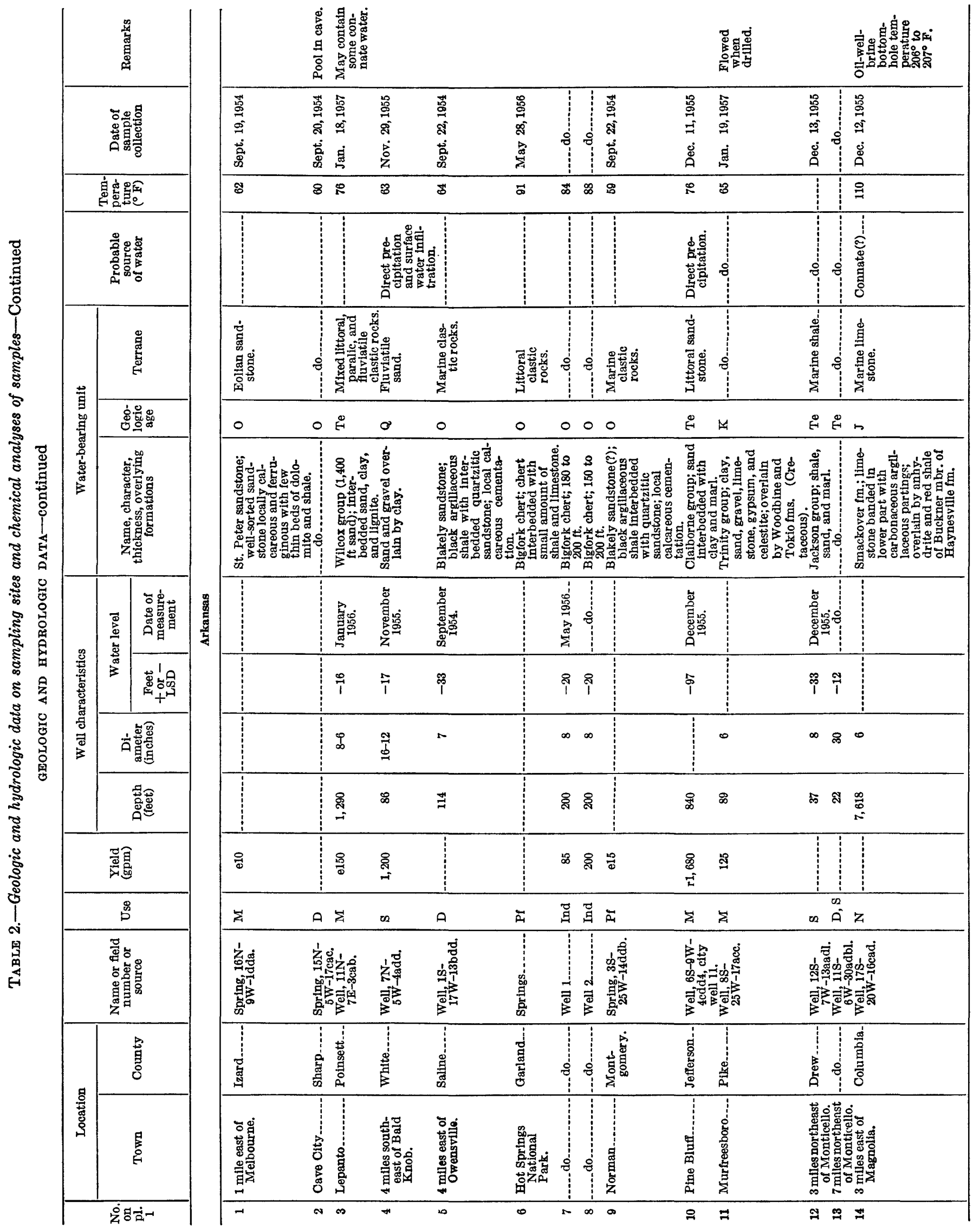




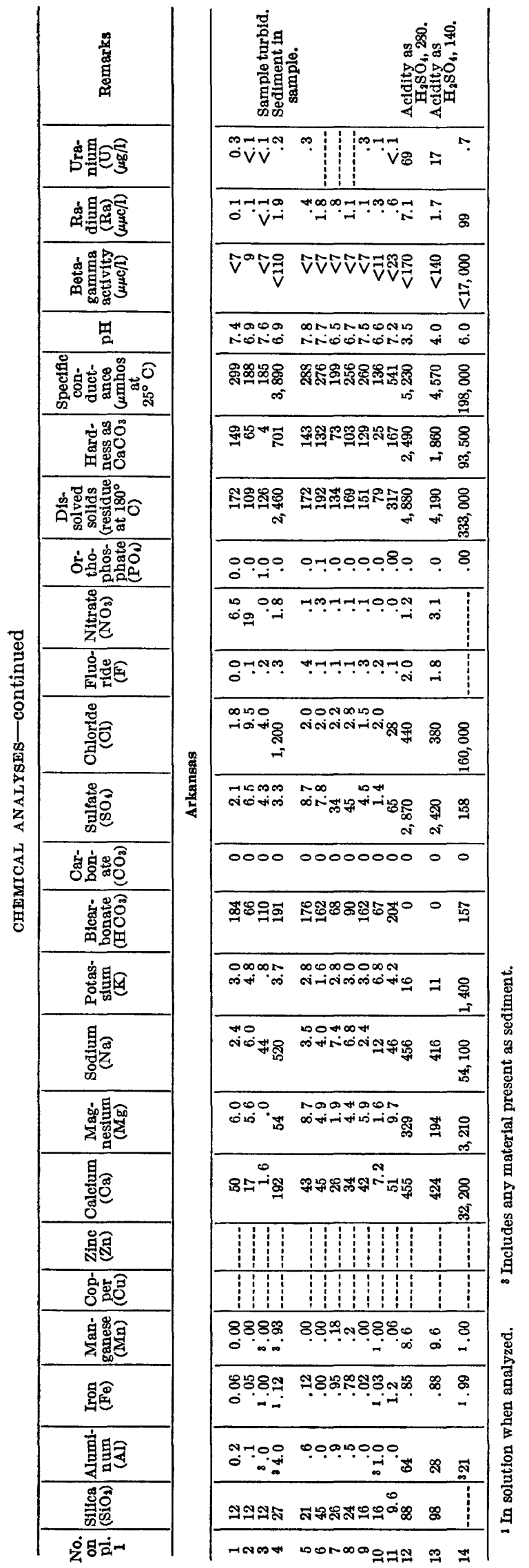



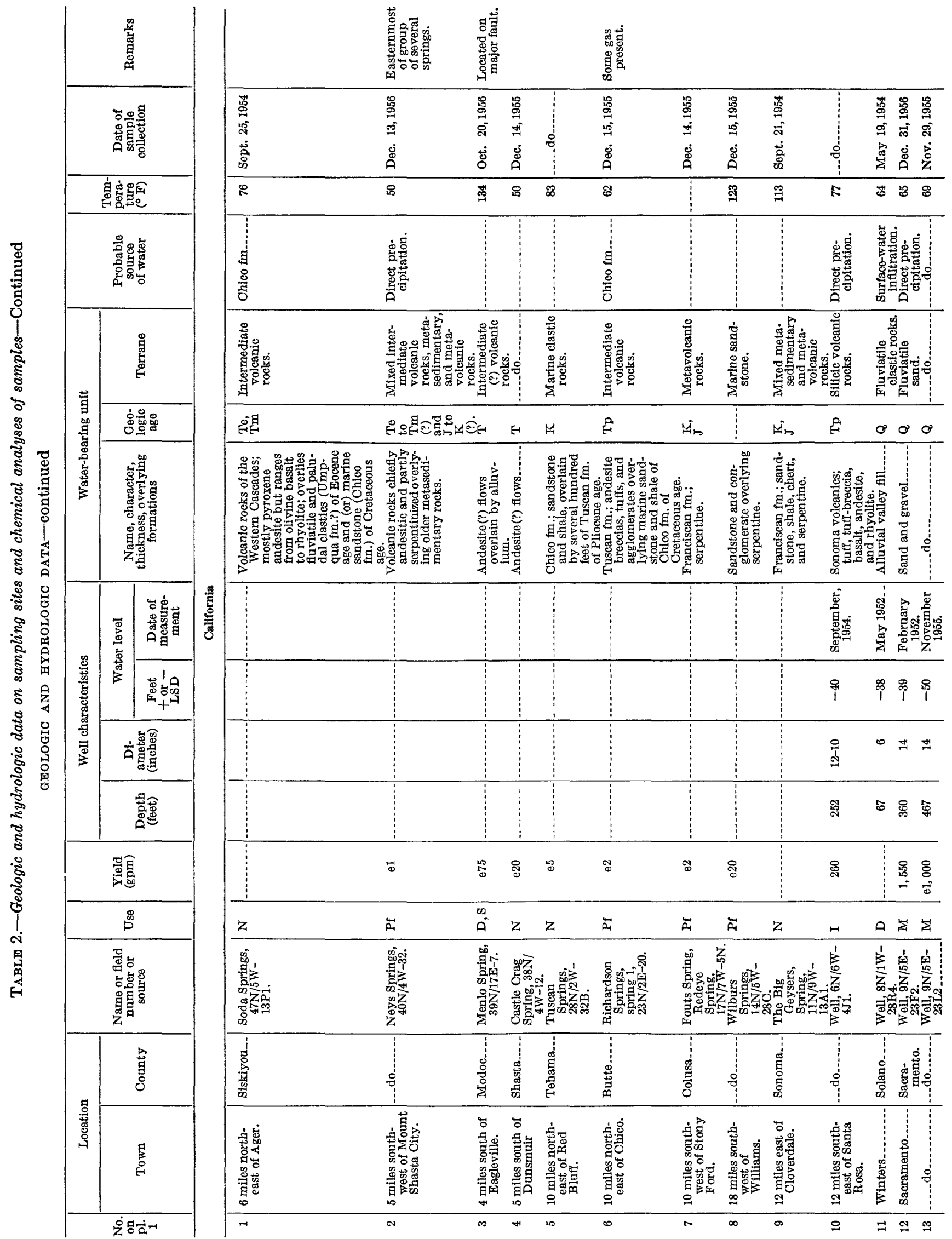


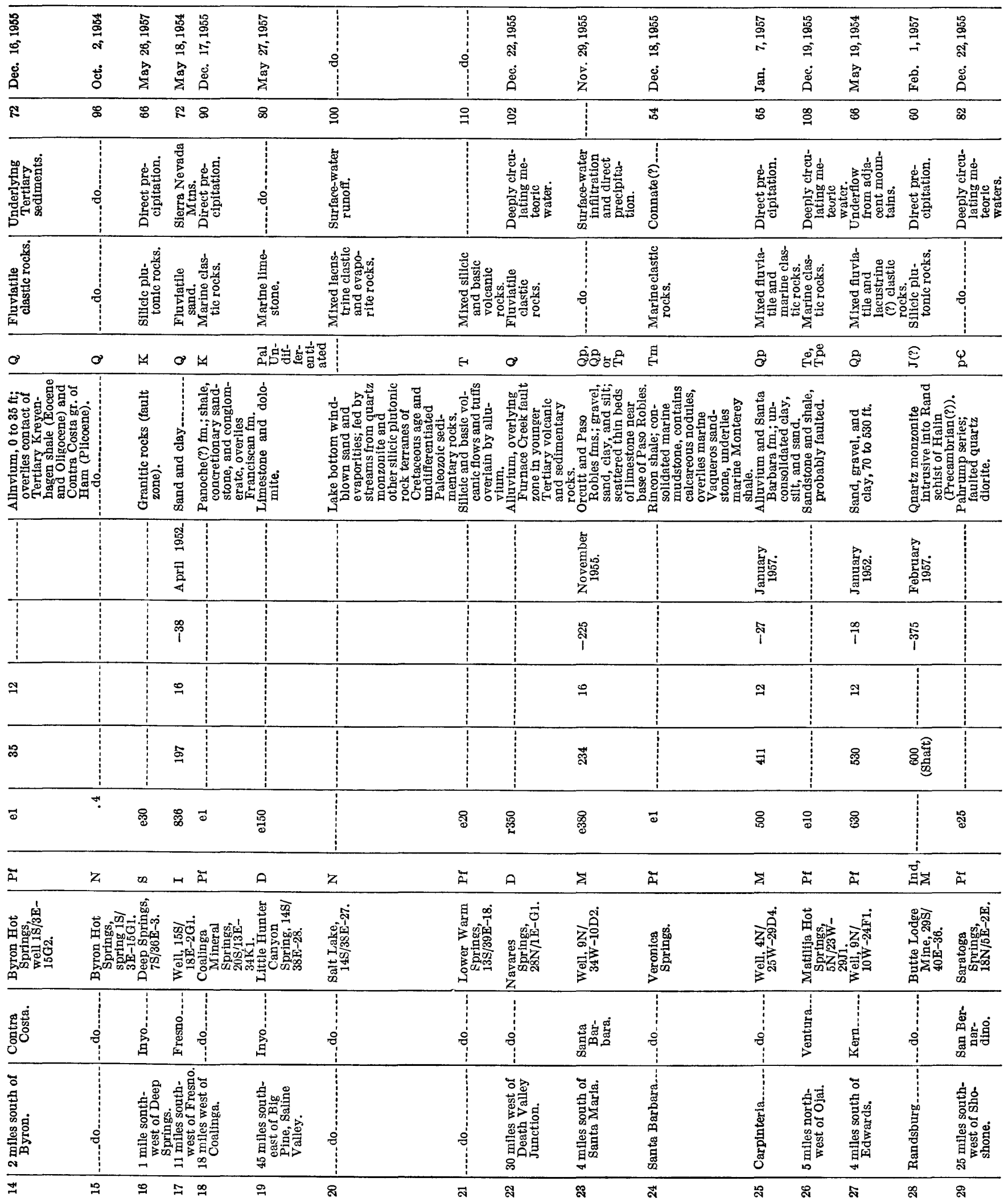




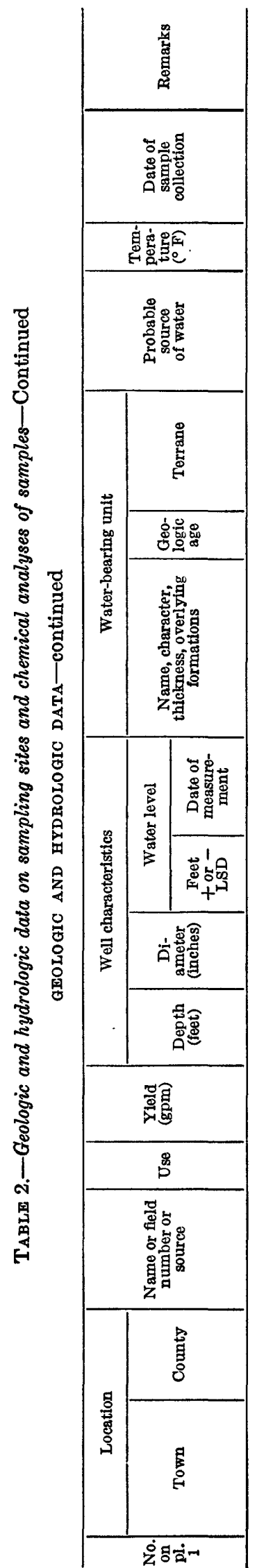

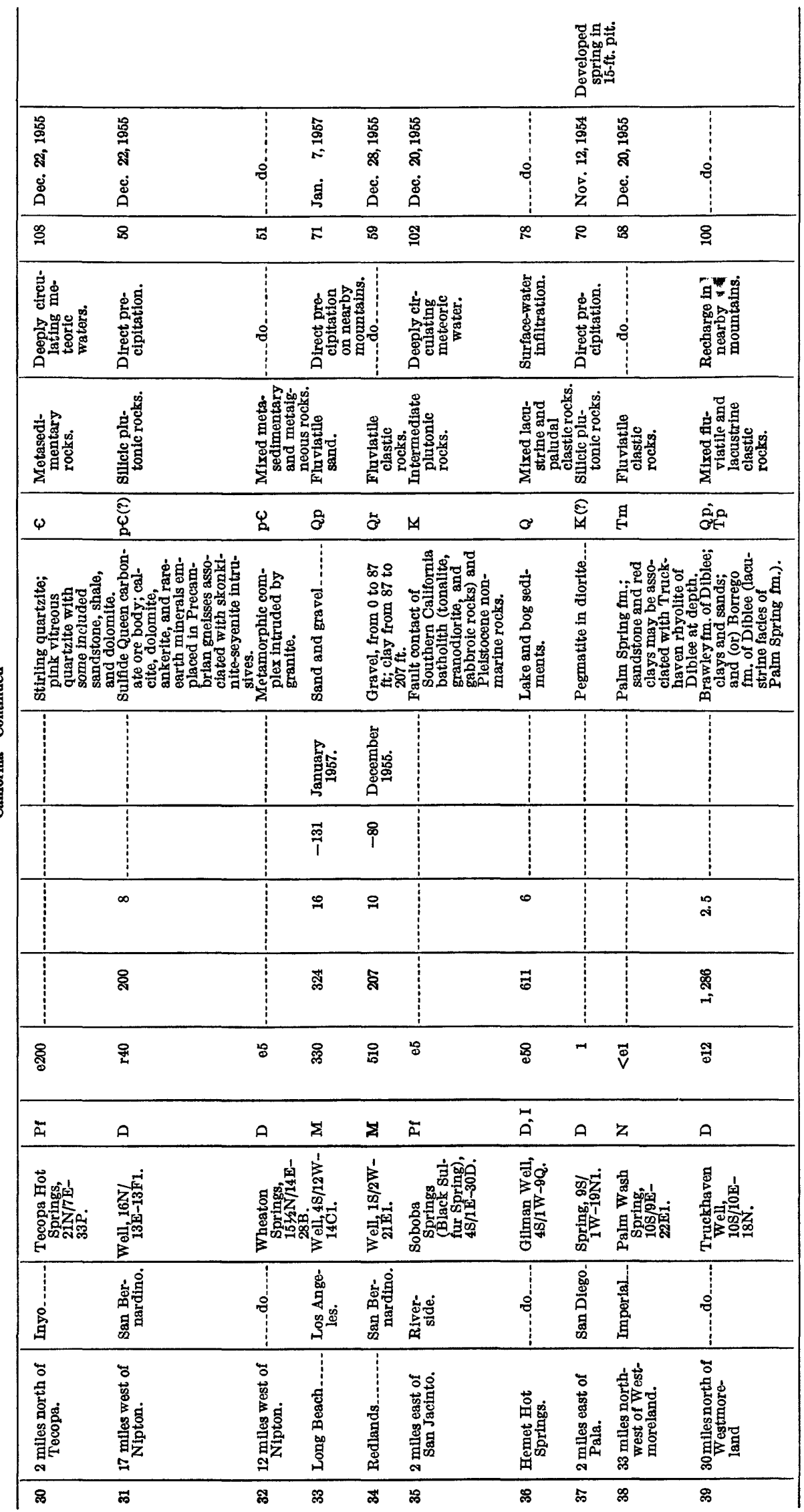


GEOLOGIC, HYDROLOGIC, AND CHEMICAL DATA

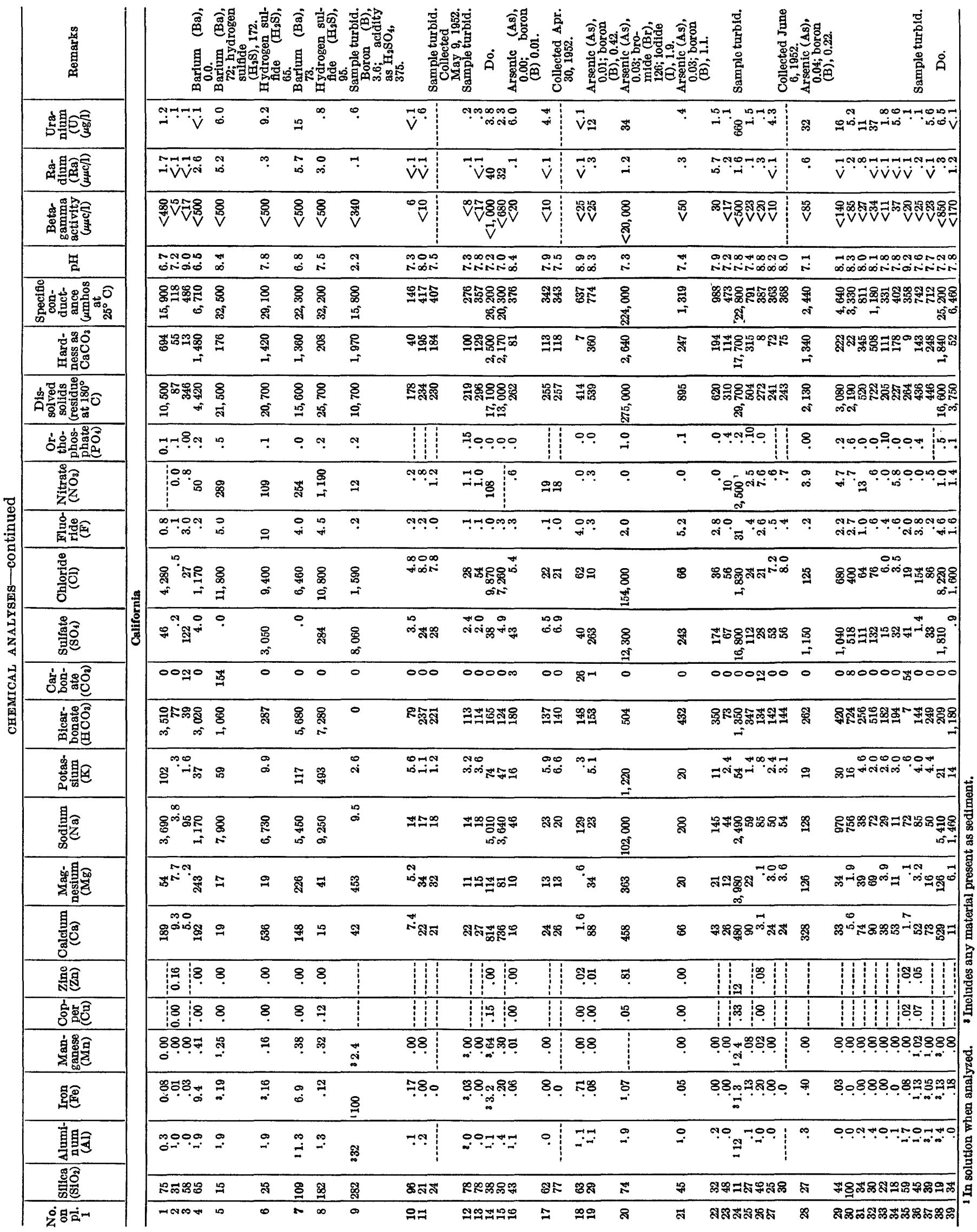




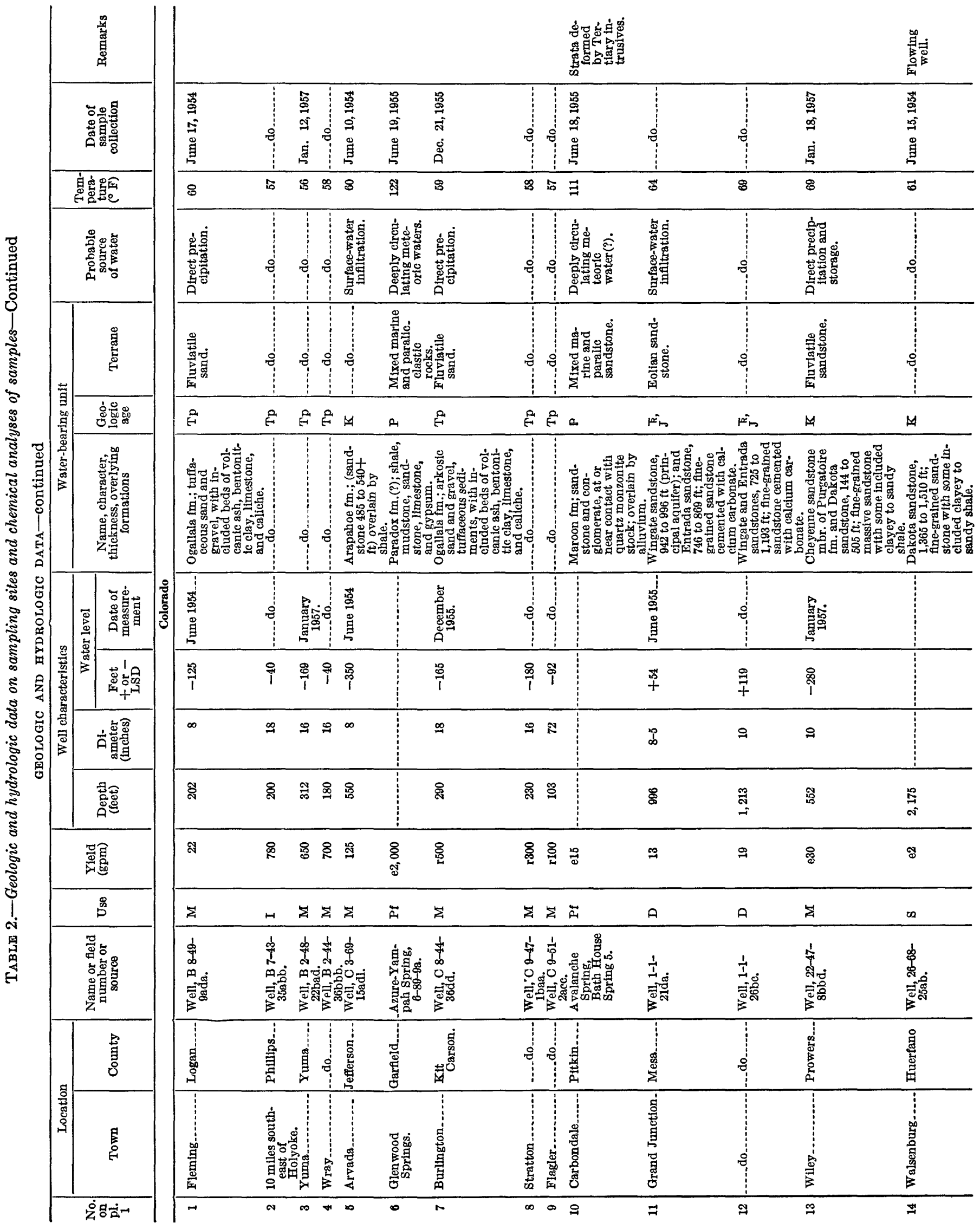


GEOLOGIC, HYDROLOGIC, AND CHEMICAL DATA

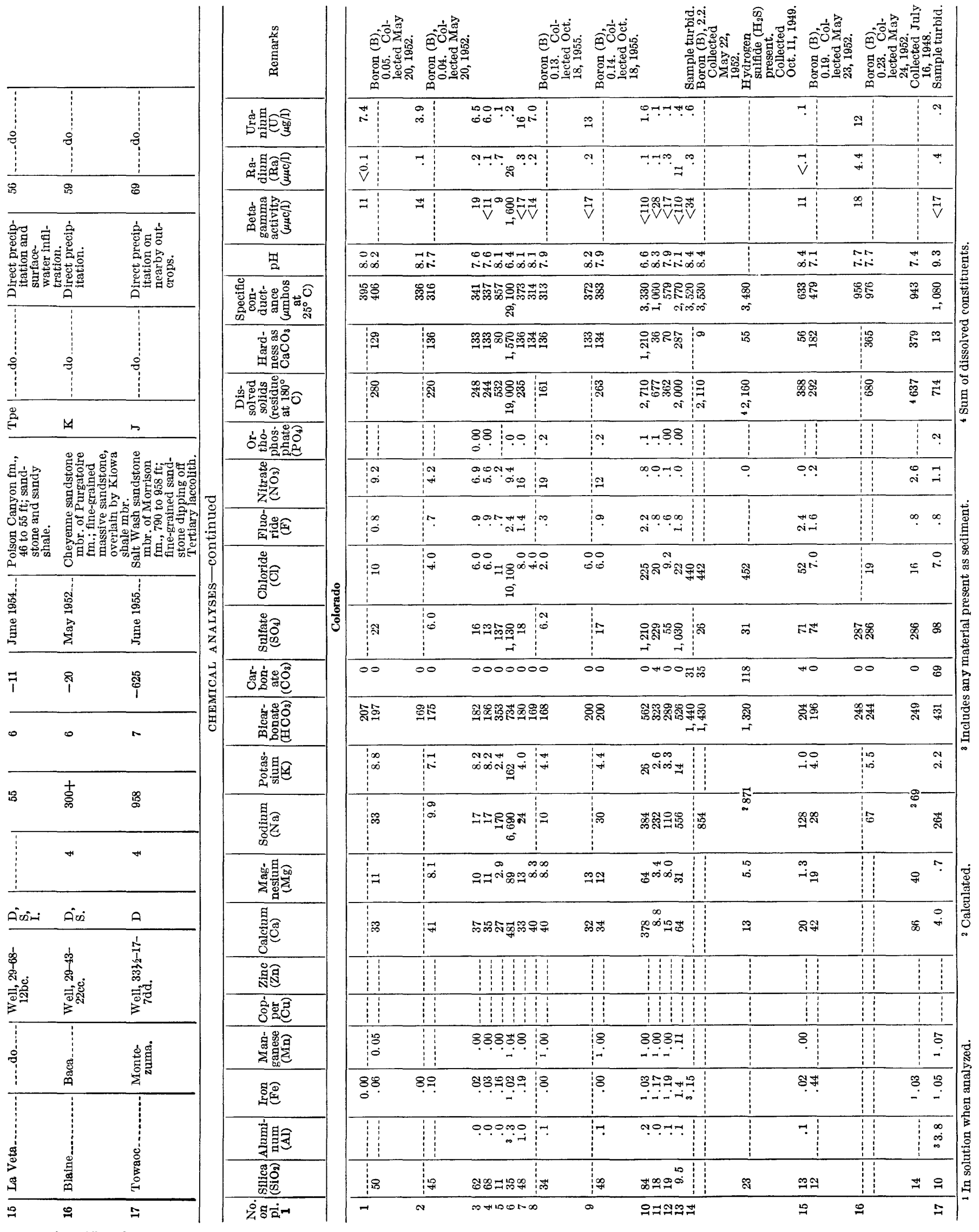




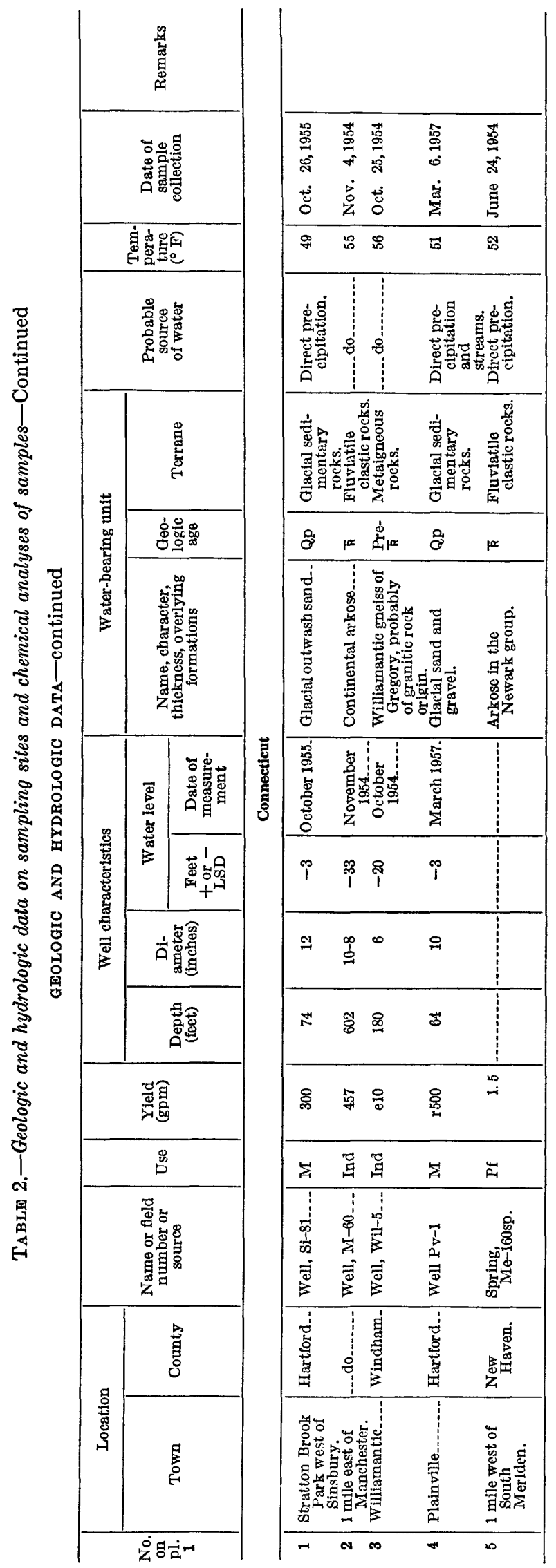


GEOLOGIC, HYDROLOGIC, AND CHEMICAL DATA

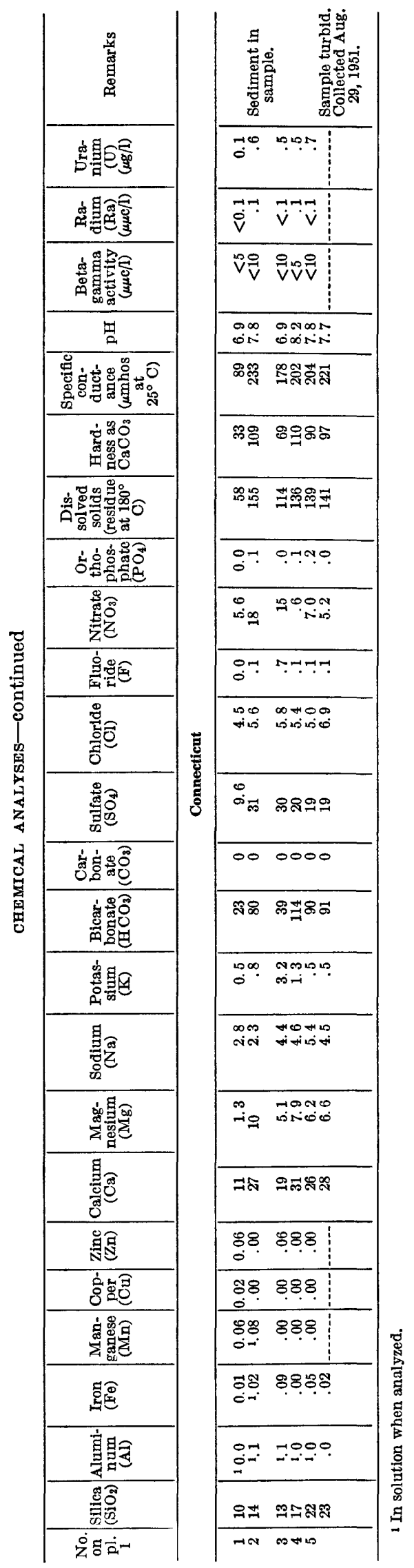




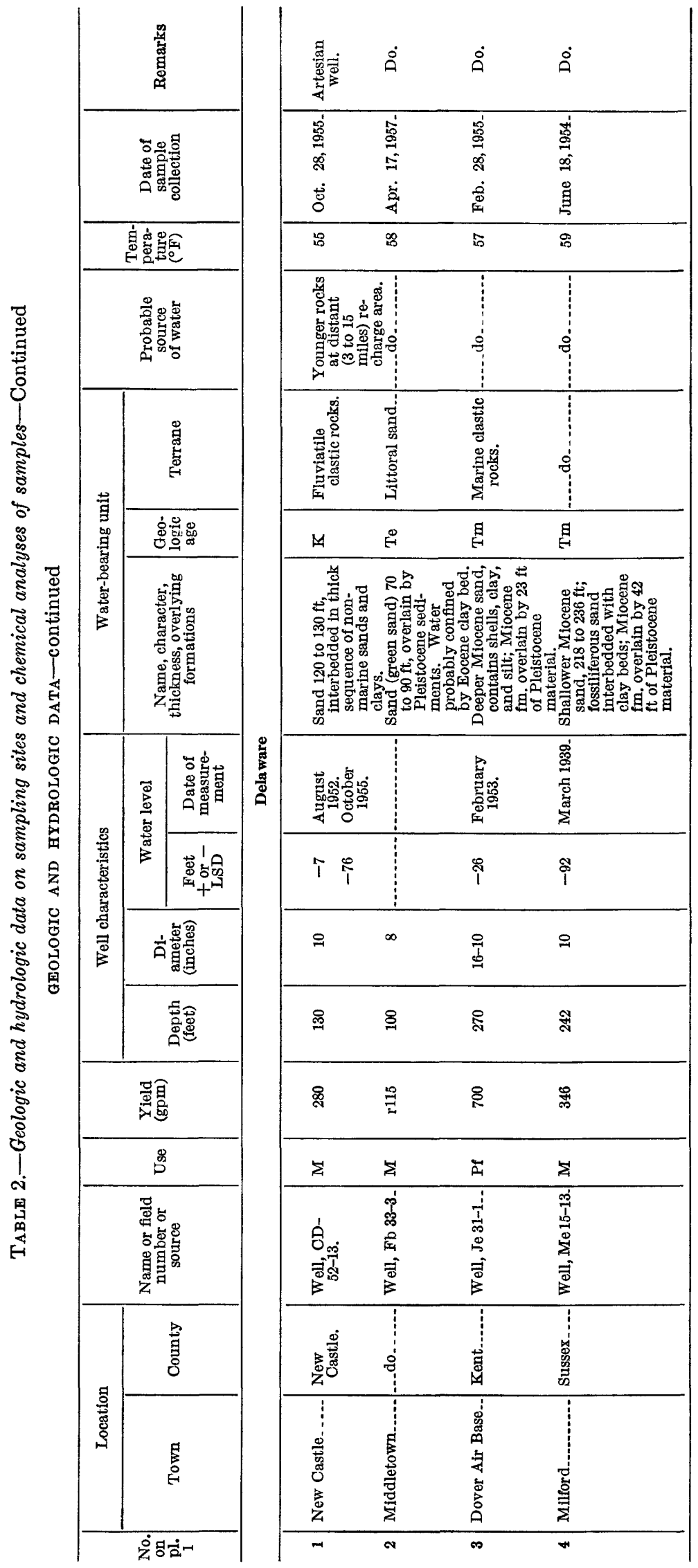


GEOLOGIC, HYDROLOGIC, AND CHEMICAL DATA

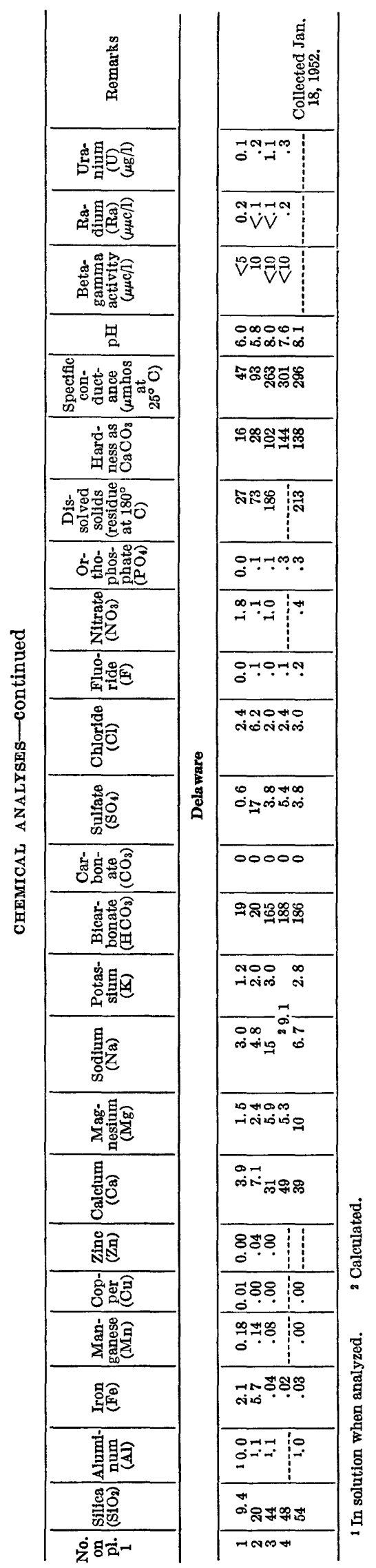




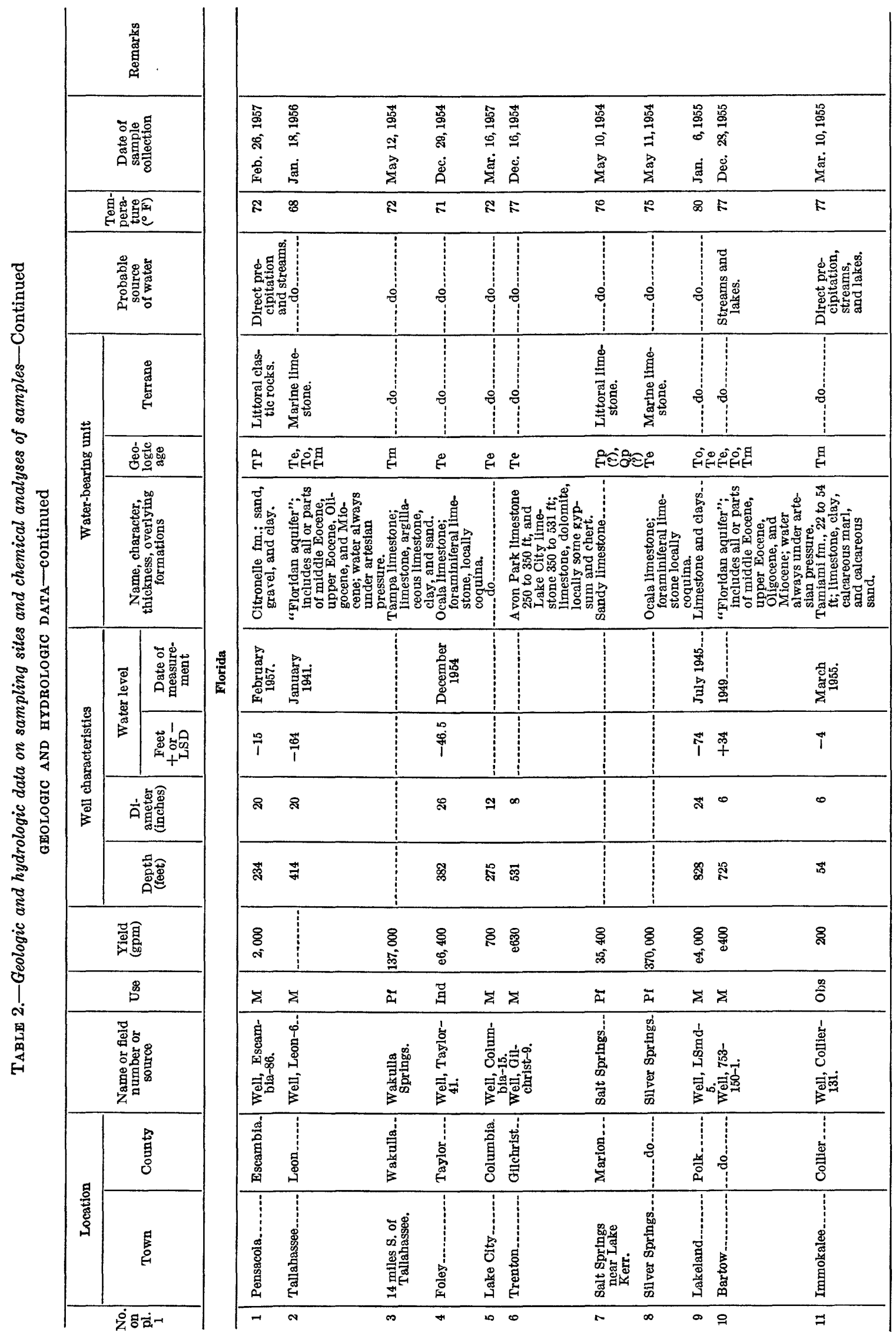


GEOLOGIC, HYDROLOGIC, AND CHEMICAL DATA

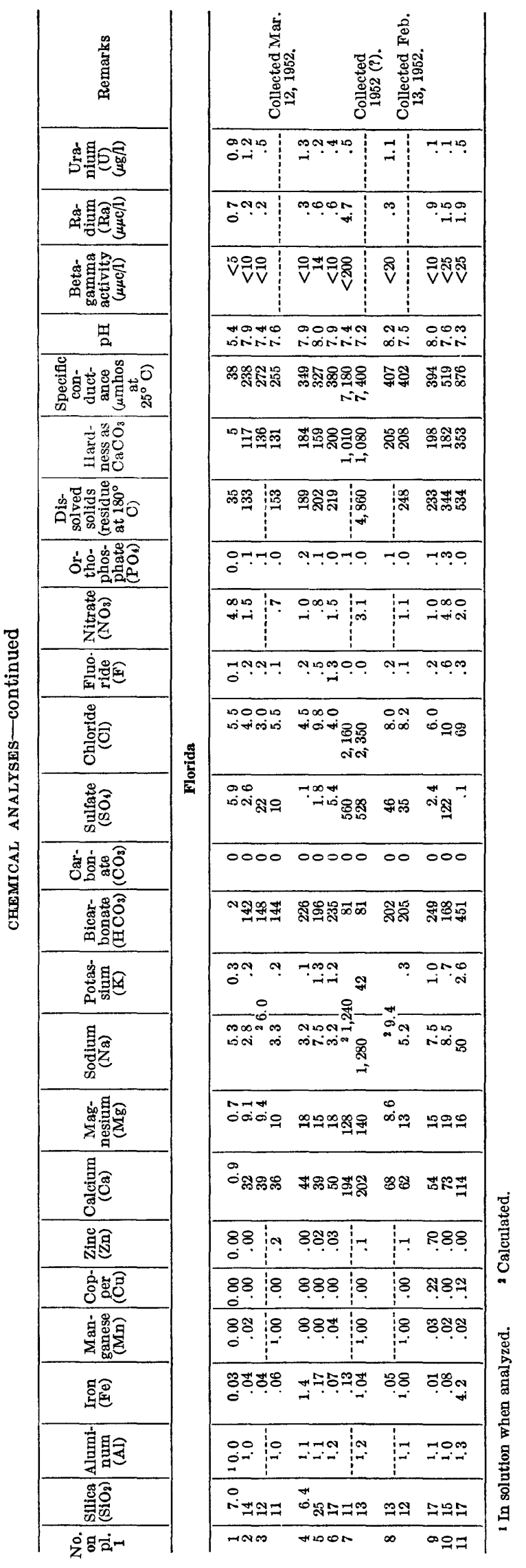




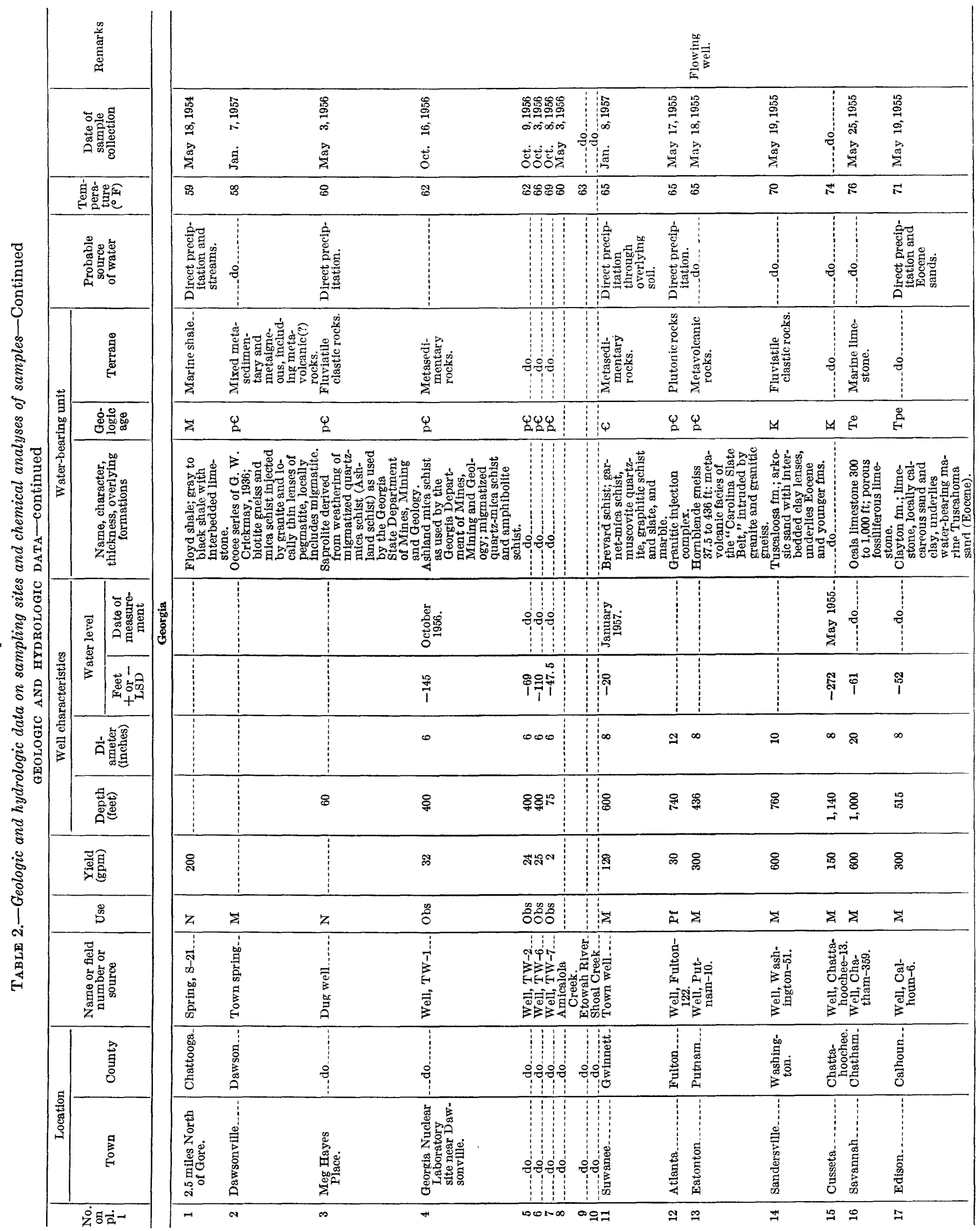




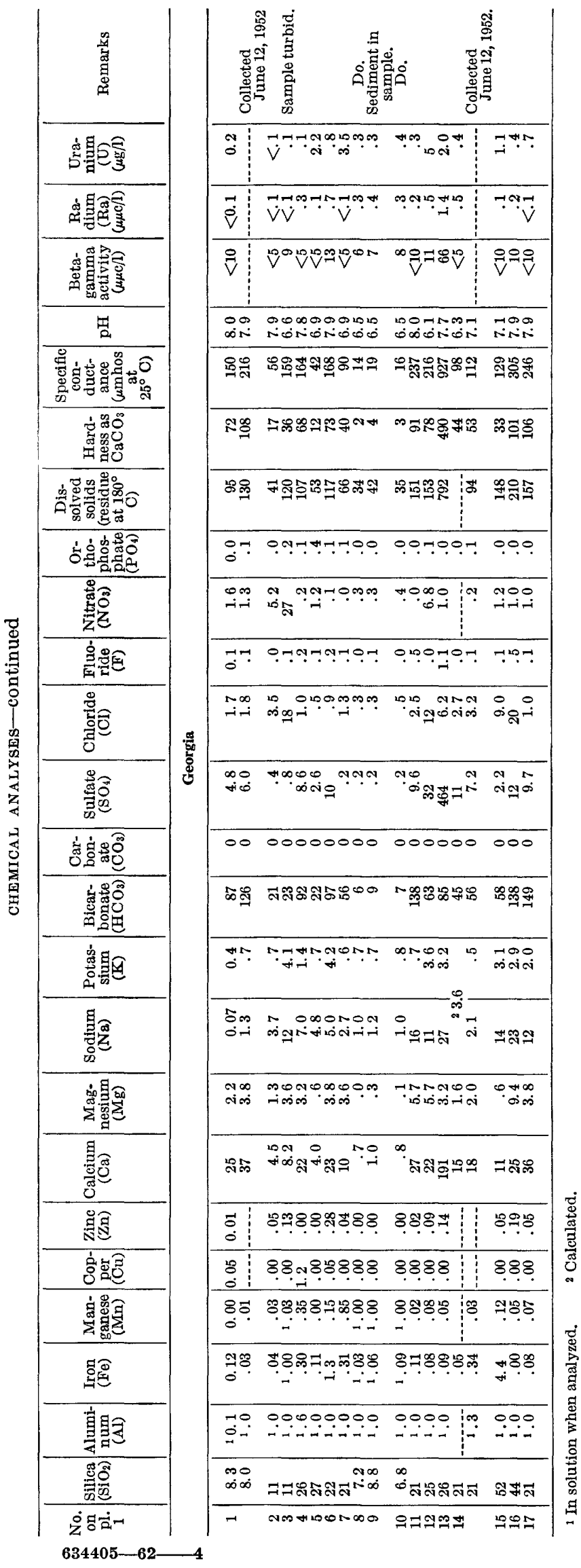




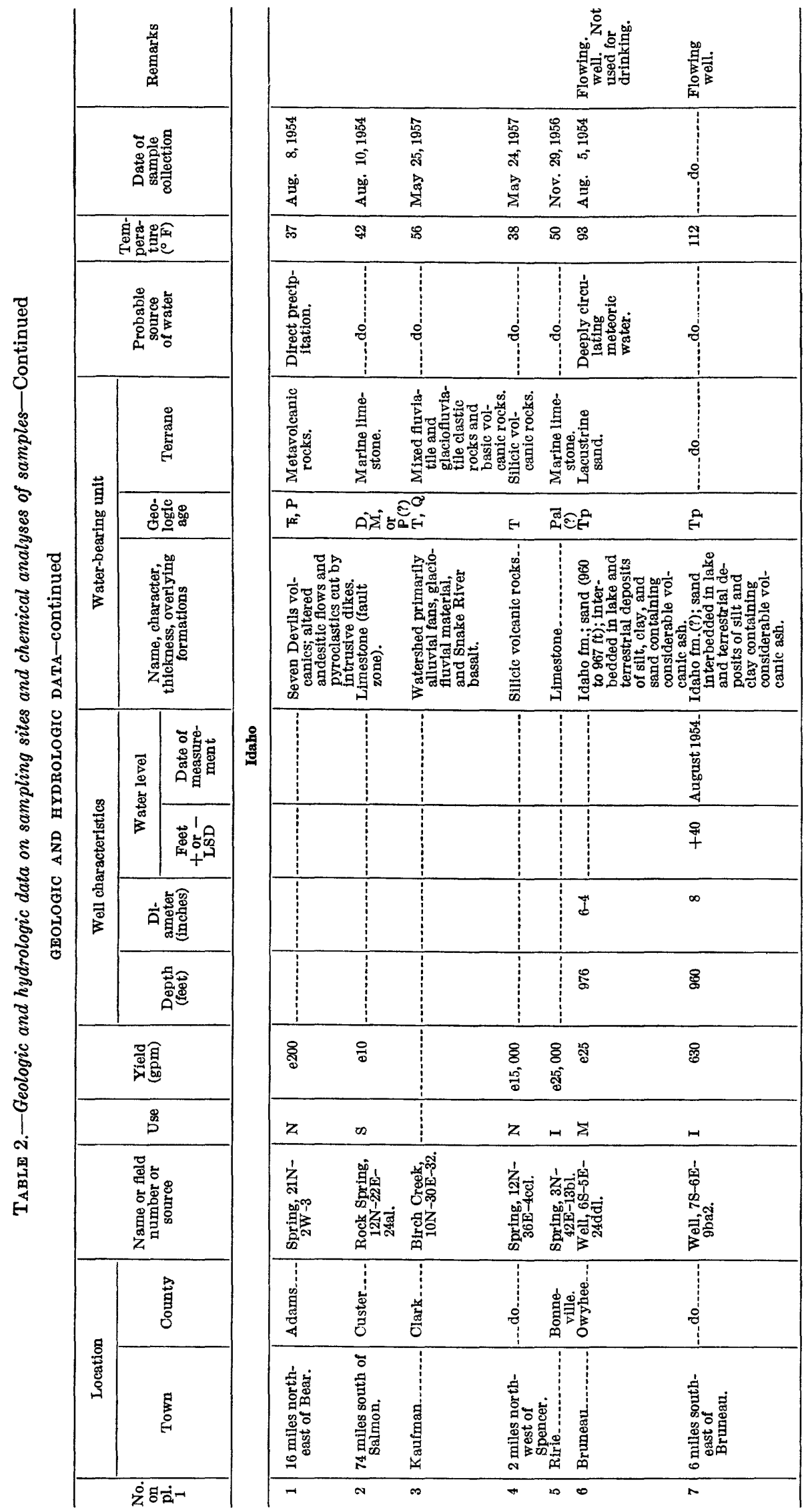


GEOLOGIC, HYDROLOGIC, AND CHEMICAL DATA

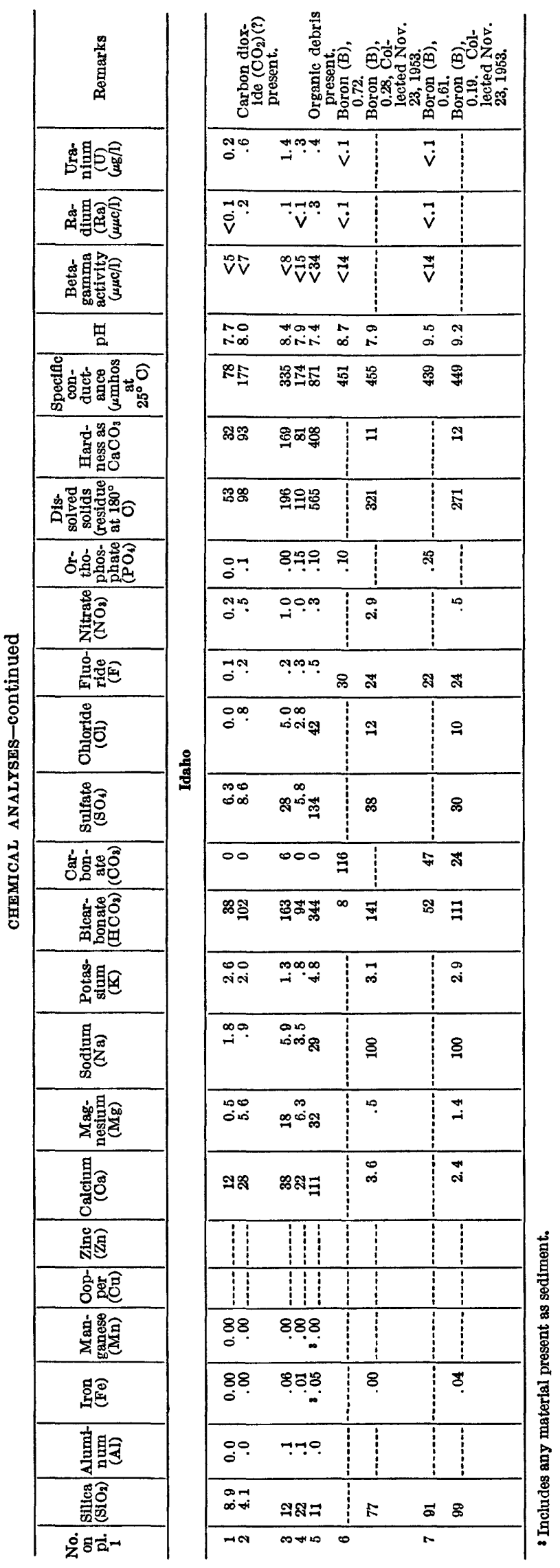




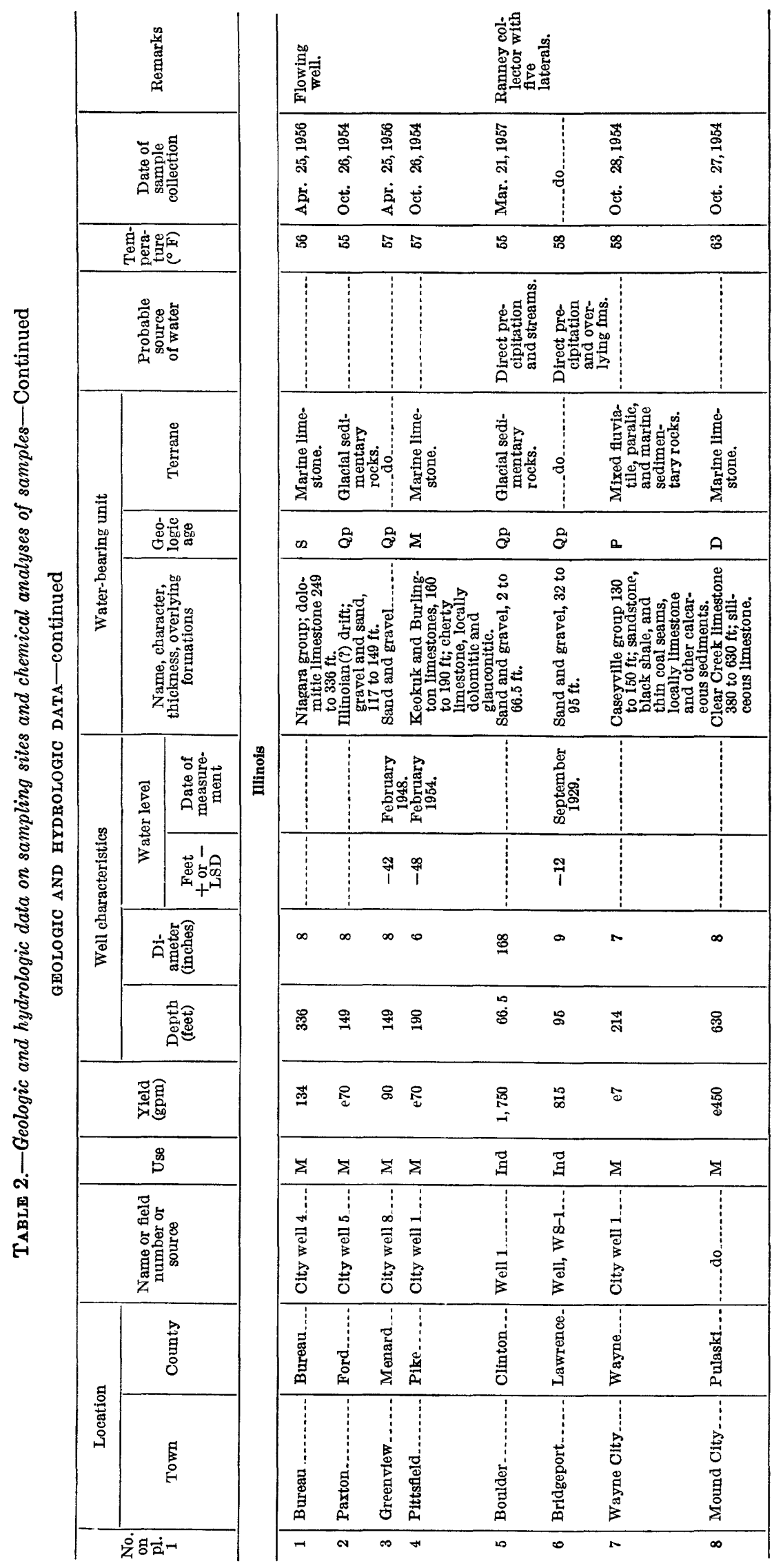


GEOLOGIC, HYDROLOGIC, AND CHEMTCAL DATA

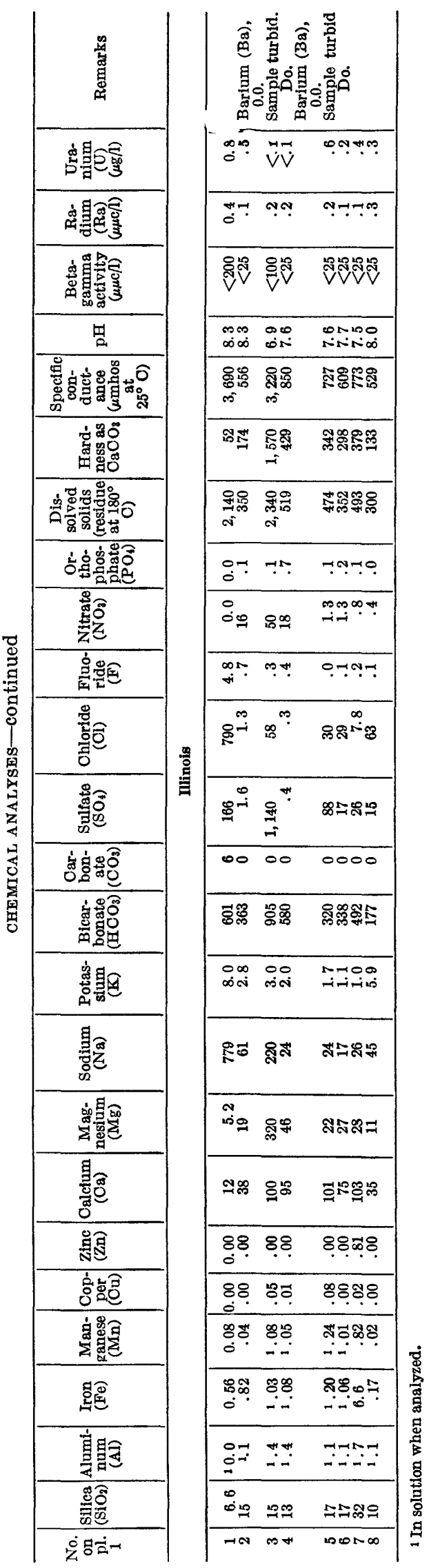




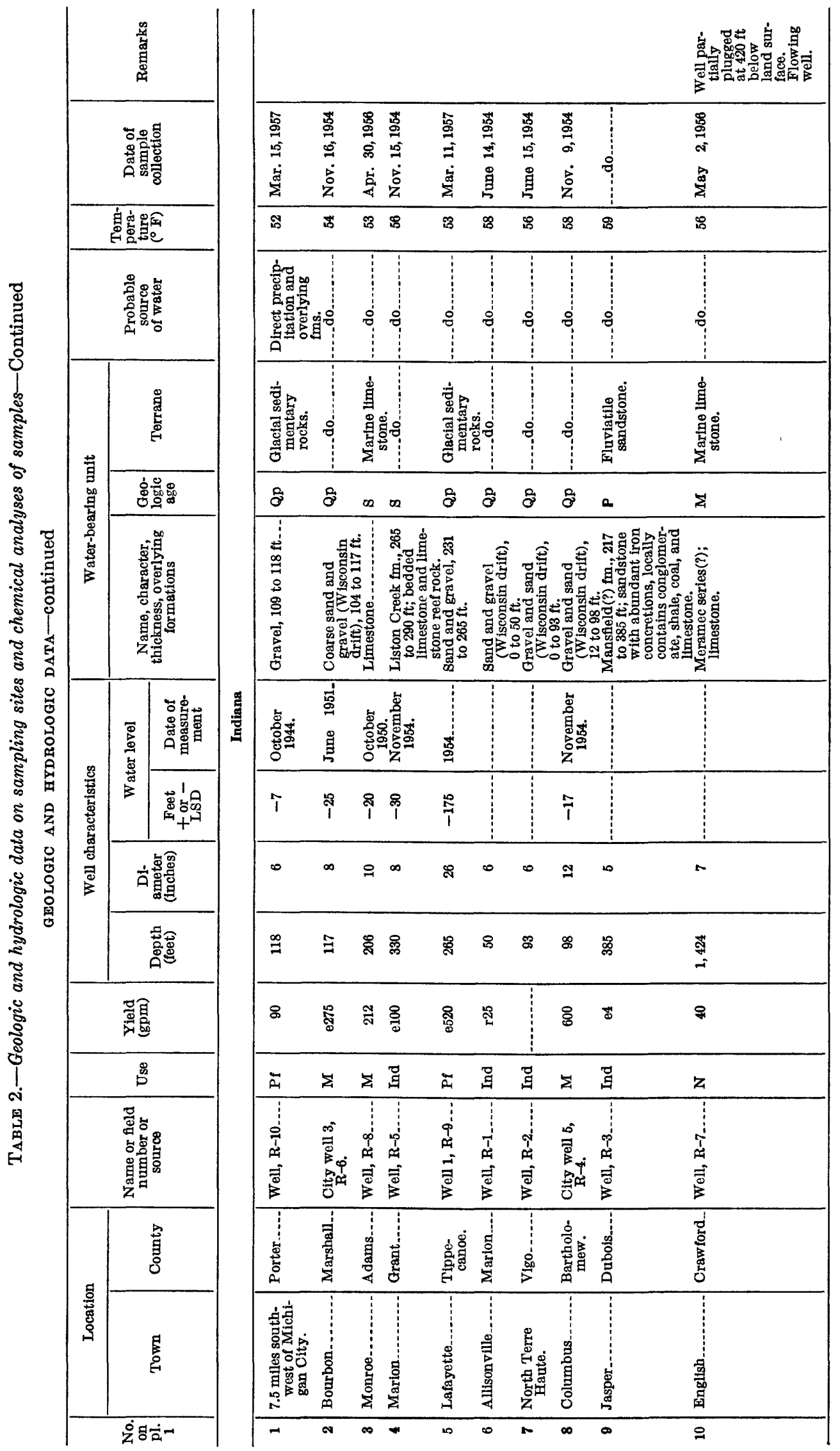




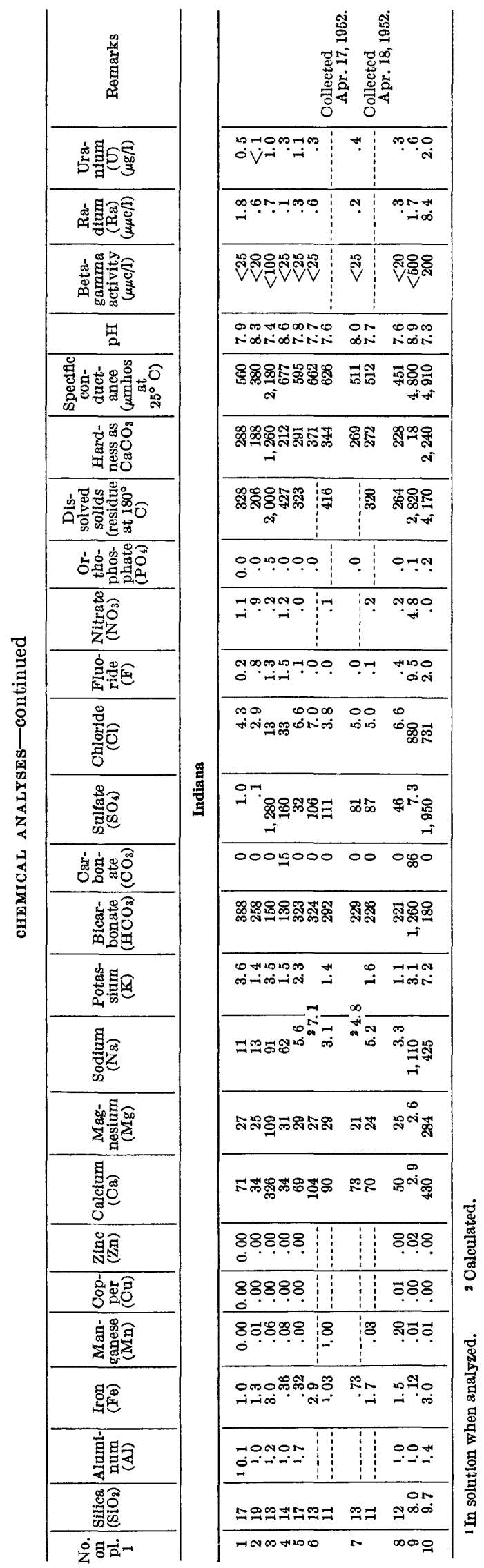


DATA ON URANIUM AND RADIUM IN GROUND WATER IN UNITED STATES, 1954 TO 1957

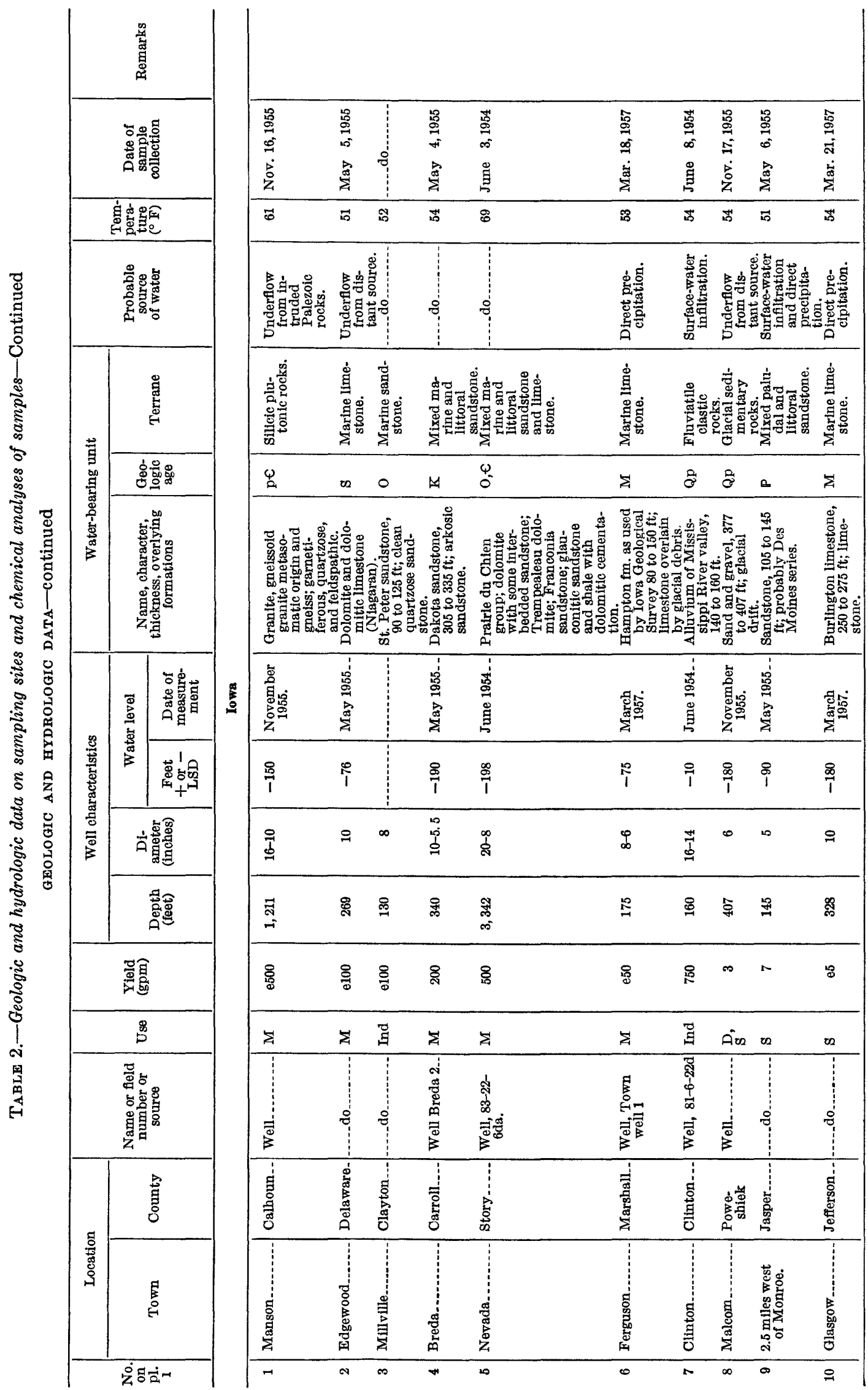


GEOLOGIC, HYDROLOGIC, AND CHEMICAL DATA

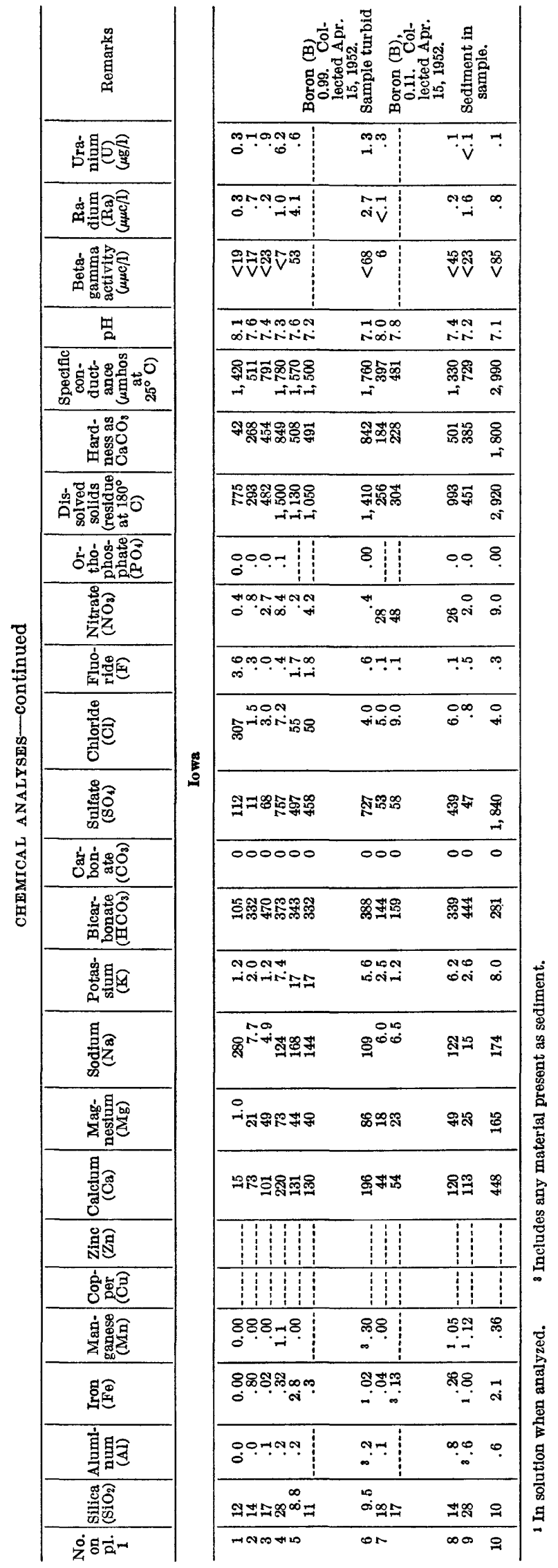




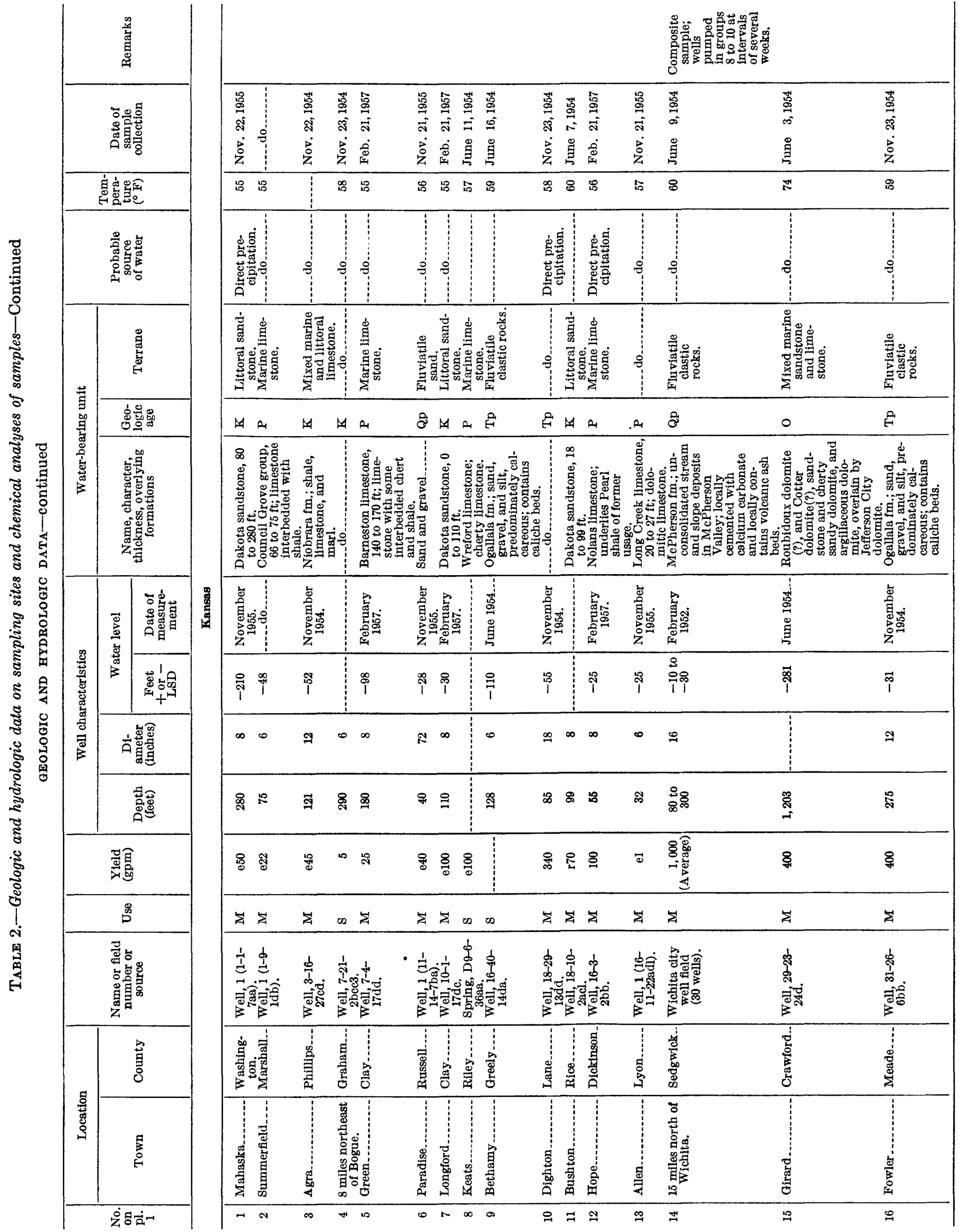


GEOLOGIC, HYDROLOGIC, AND CHEMICAL DATA

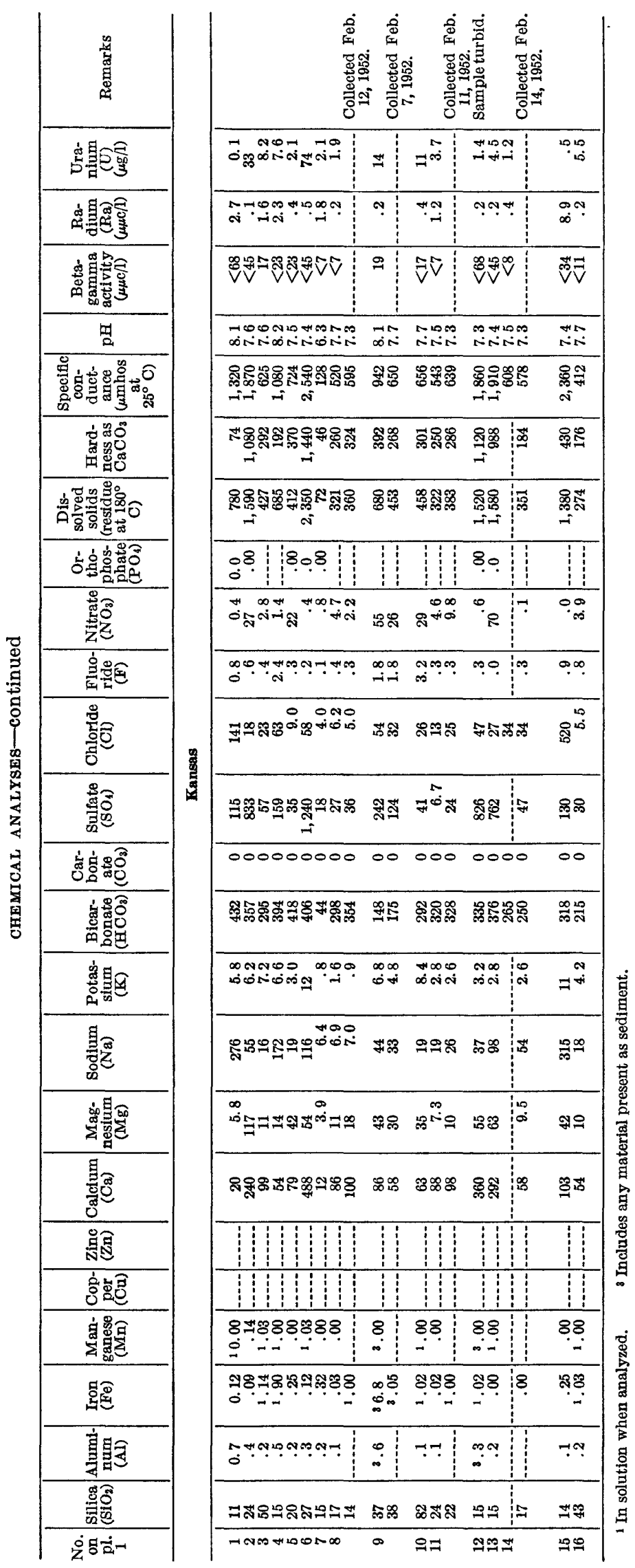




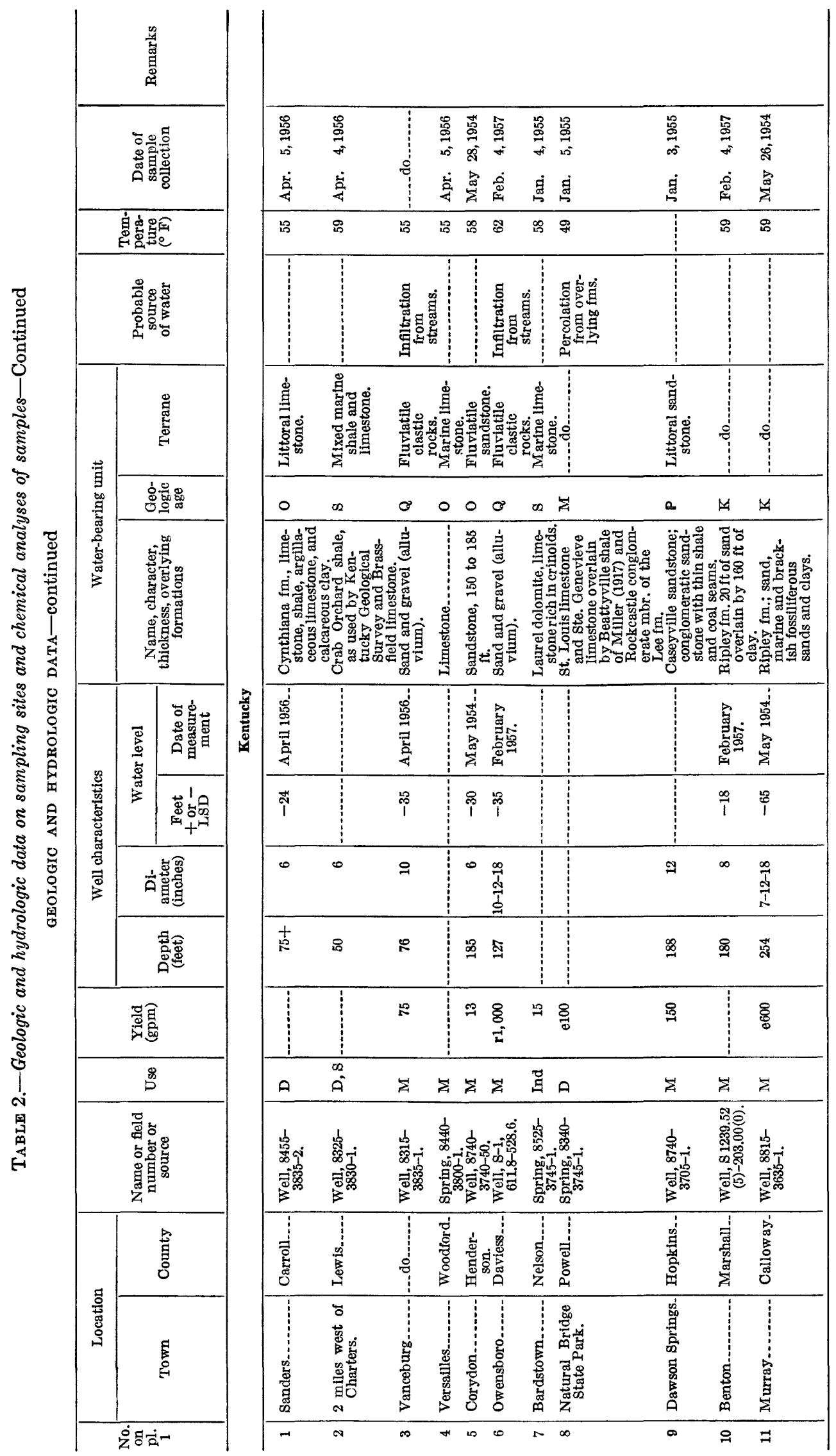




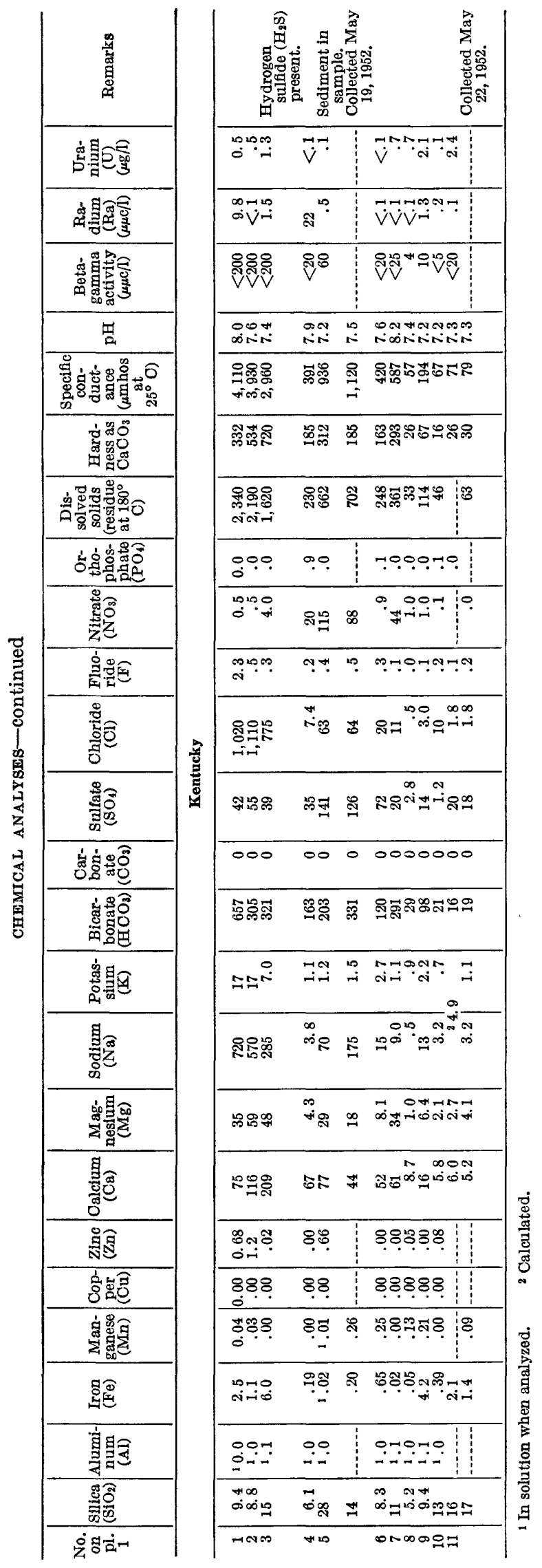




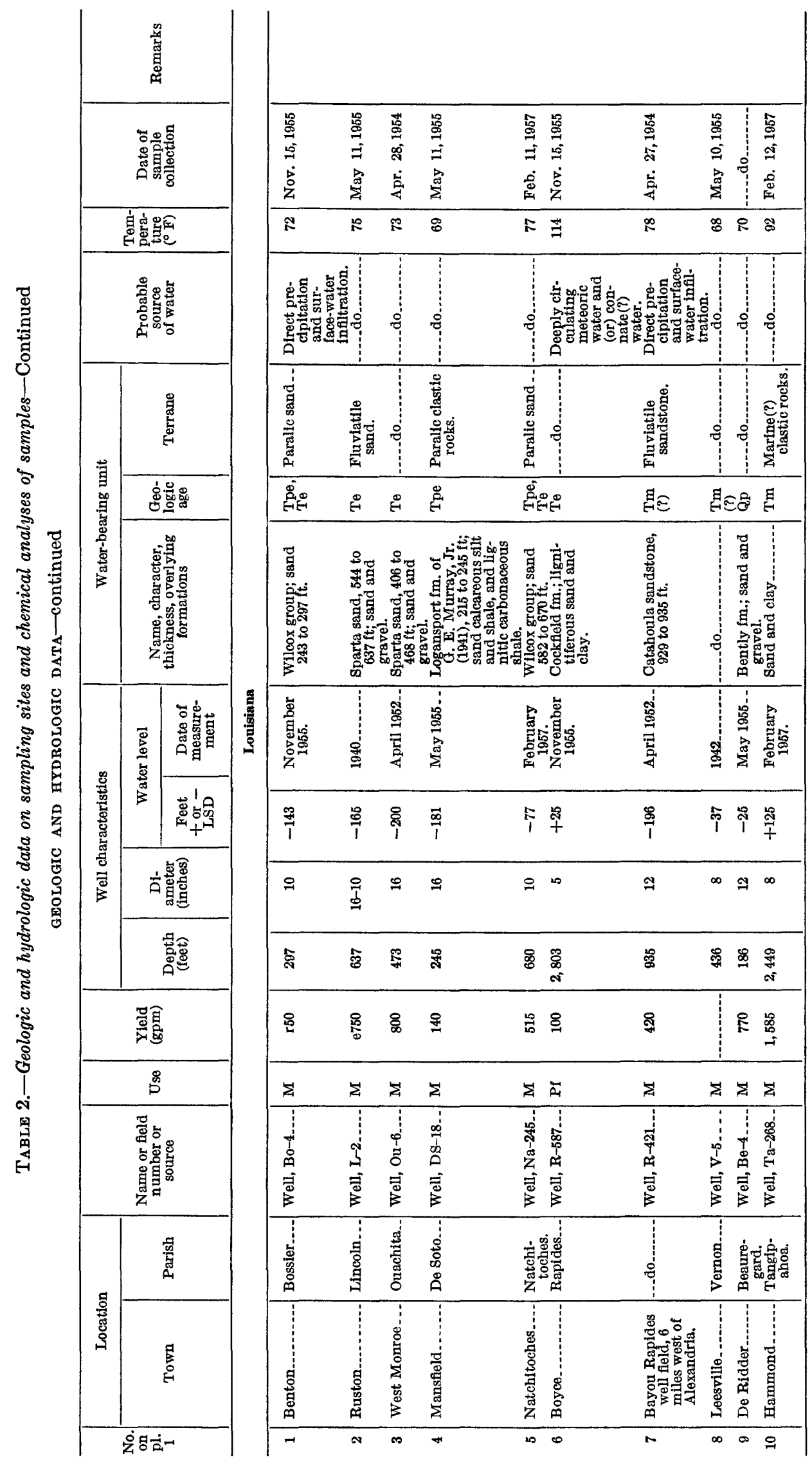


GEOLOGIC, HYDROLOGIC, AND CHEMICAL DATA

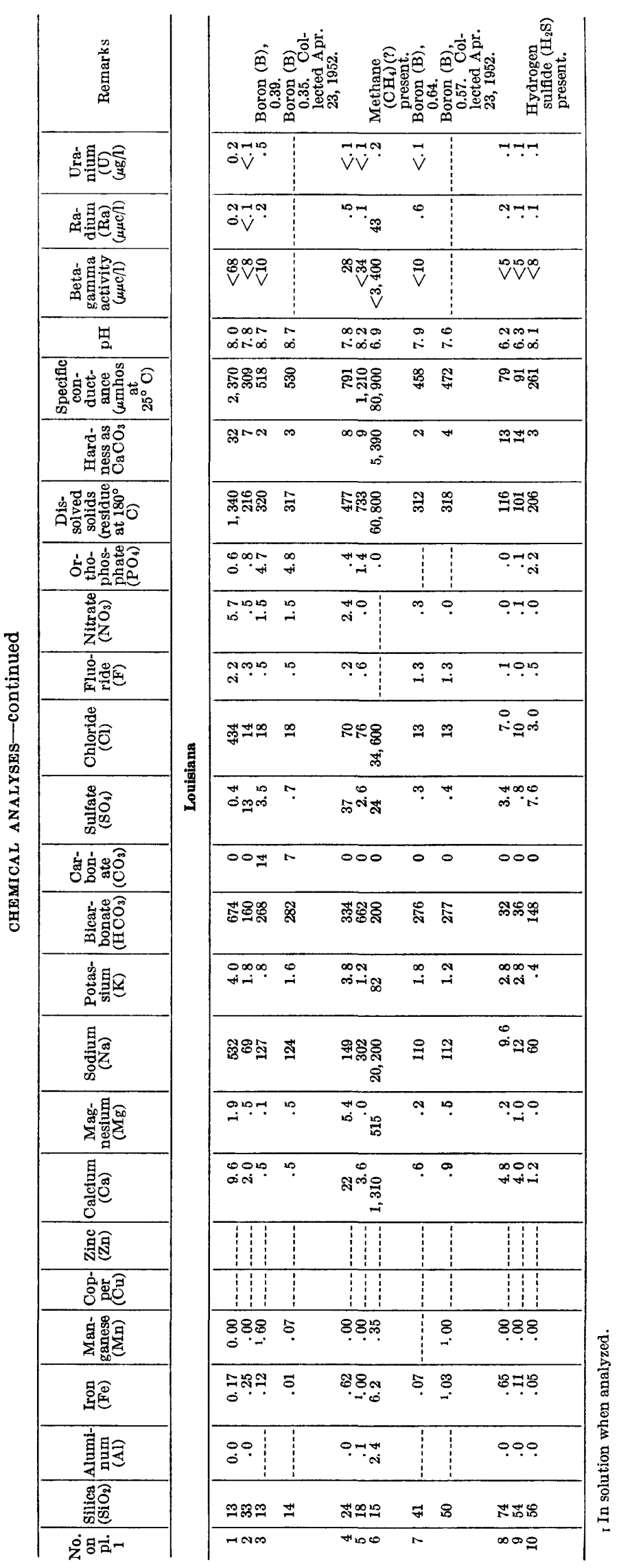




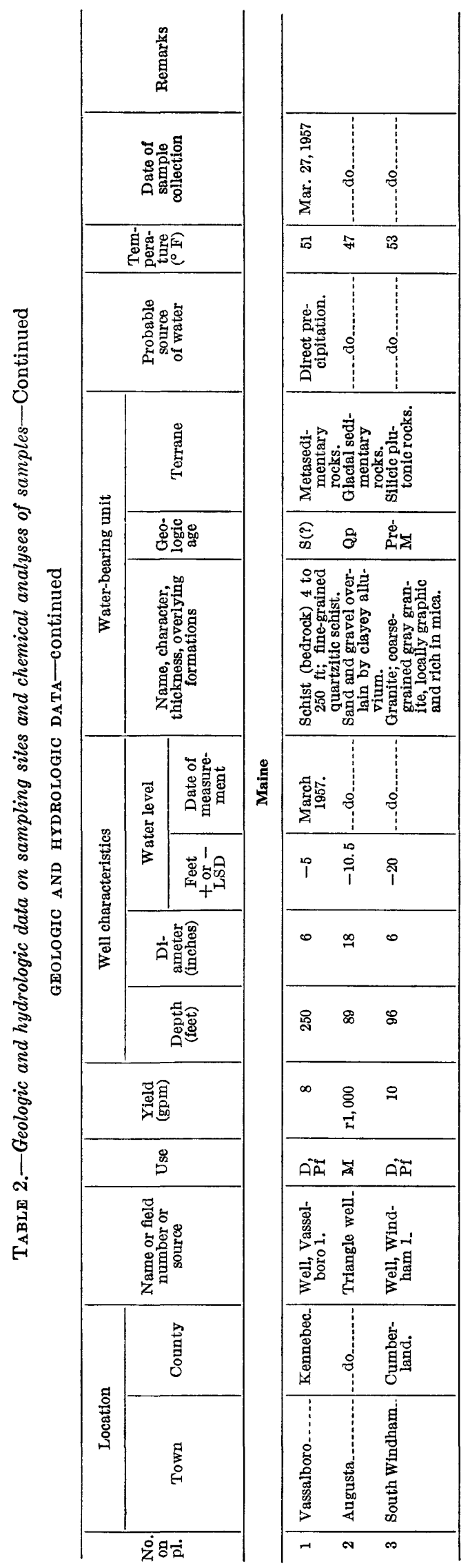


GEOLOGIC, HYDROLOGIC, AND CHEMICAL DATA

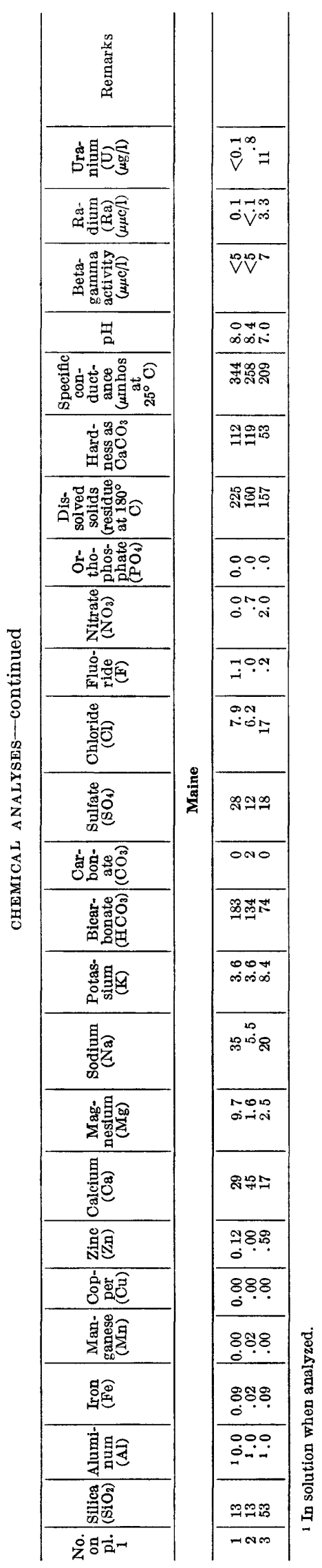




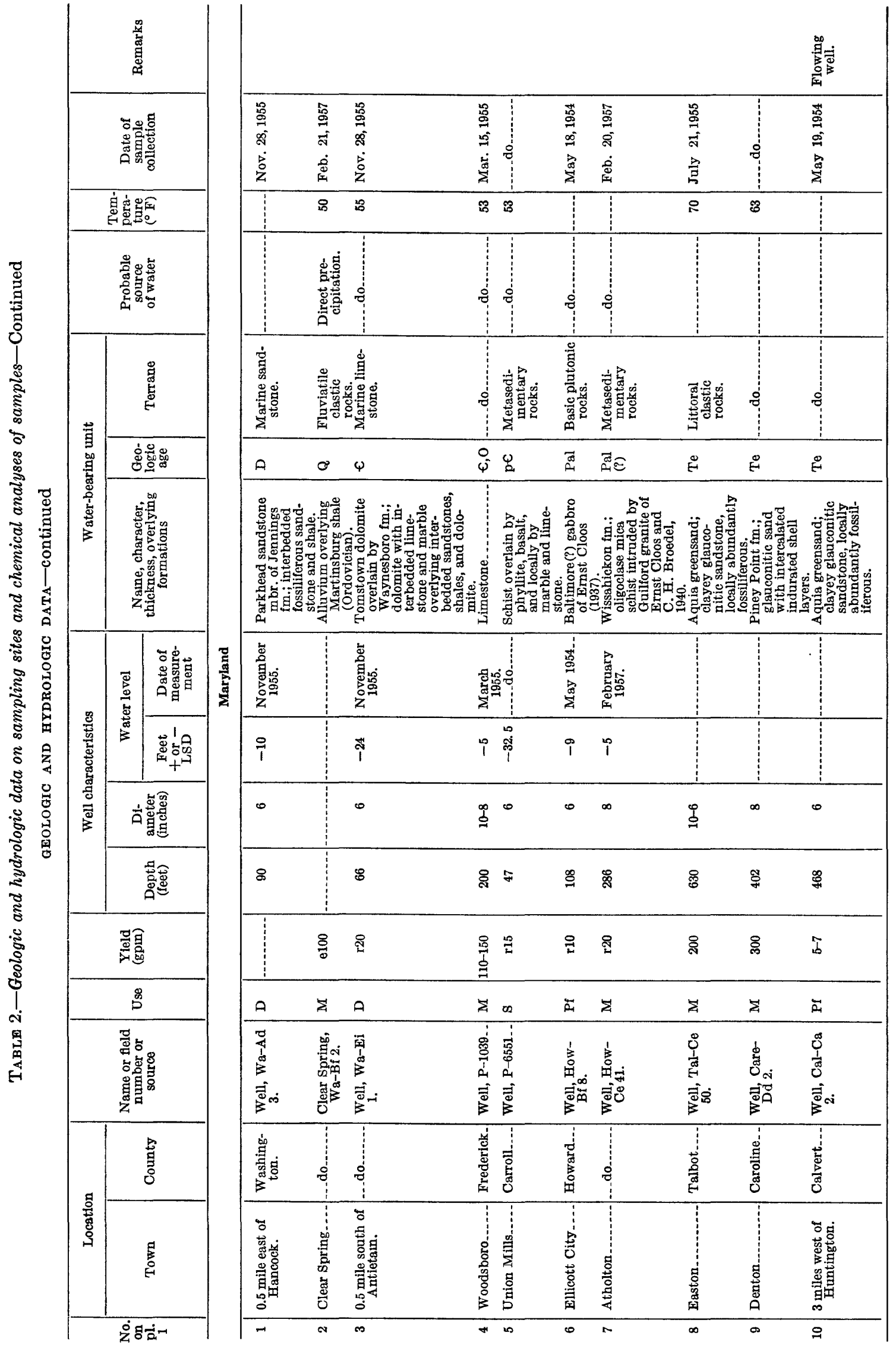


GEOLOGIC, HYDROLOGIC, AND CHEMICAL DATA

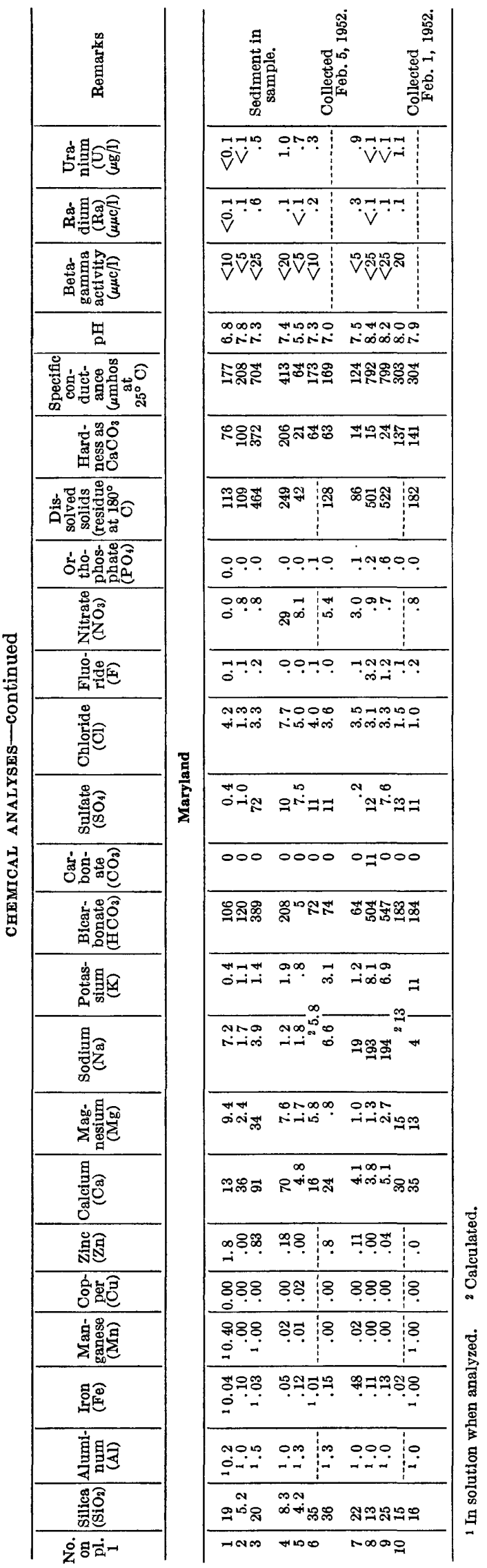




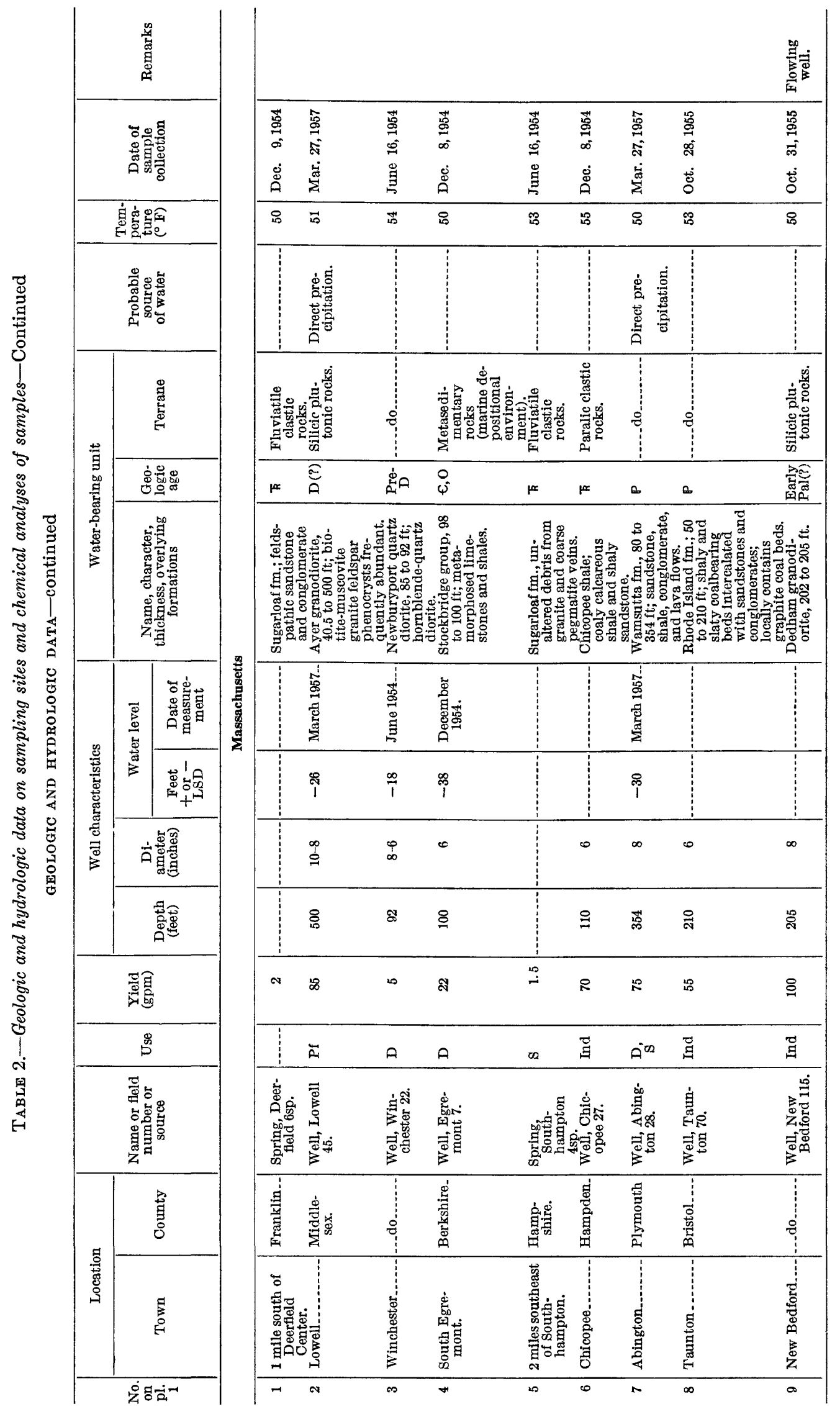


GEOLOGIC, HYDROLOGIC, AND CHEMICAL DATA

\begin{tabular}{|c|c|c|c|c|}
\hline 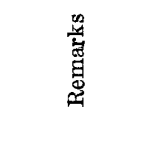 & & \multicolumn{3}{|c|}{ 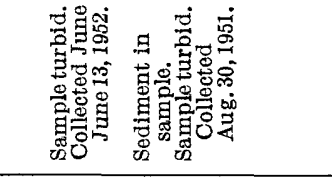 } \\
\hline 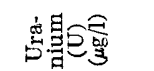 & & क्ष巾: & 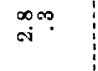 & $\stackrel{0}{-\vec{V}} \vec{V} \dot{V}-\dot{i}$ \\
\hline ๙ & & 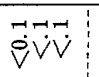 & $\because \because$ & $\because+100$ \\
\hline 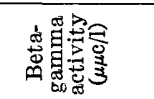 & & $\stackrel{m e}{*}$ & $\stackrel{\nabla}{\nabla V}$ & অ. \\
\hline 思 & & 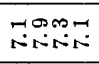 & 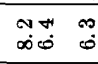 & 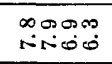 \\
\hline 曾 & & 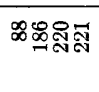 & 获烒 & 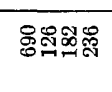 \\
\hline 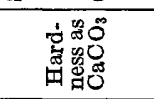 & & 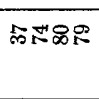 & 7 돵 & 幽 \\
\hline 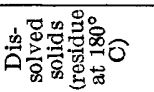 & & 망워 & 영 8 & gogoror \\
\hline 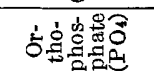 & & 0.000 & $0 \times 0$ & onam \\
\hline 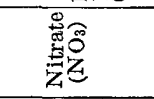 & & 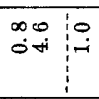 & $\operatorname{lio}_{\infty}=$ & $\pi_{4}$ \\
\hline 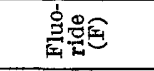 & & $0-100.4$ & 00.9 & $\because \because \infty$ \\
\hline 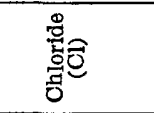 & 嫱 & F+口 & 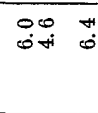 & 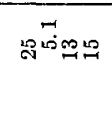 \\
\hline 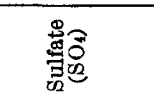 & 㺃 & 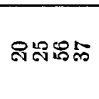 & 29 & 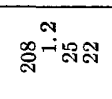 \\
\hline 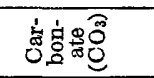 & & 0000 & 000 & 0000 \\
\hline 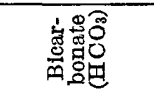 & & 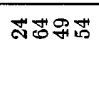 & क्षু & œִ \\
\hline 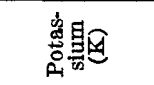 & & 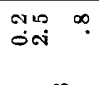 & 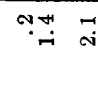 & क्वस'? \\
\hline 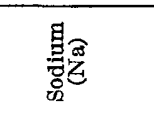 & & 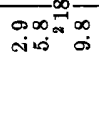 & 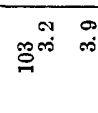 & 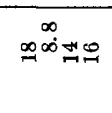 \\
\hline 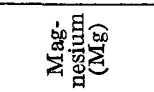 & & 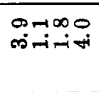 & $\because+\infty$ & $\begin{array}{l}\min \infty \\
\text { givin: }\end{array}$ \\
\hline 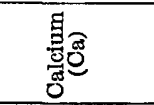 & & 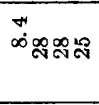 & $\dddot{9}_{\infty}$ & 电式 \\
\hline ํㅗㅀ & & $8: 0$ & 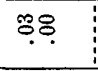 & 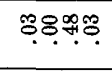 \\
\hline 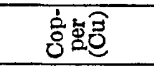 & & \begin{tabular}{l|l}
88 & \\
0 & \\
\end{tabular} & 88 & 8888 \\
\hline 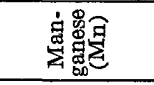 & & $\begin{array}{l:l}88 \\
0\end{array}$ & 88 & ๑규ำ \\
\hline 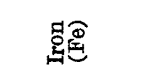 & & 列 & ำ & 迎 \\
\hline 夏䝭 & & $\begin{array}{l:l}00 & \\
\vdots- & -:\end{array}$ & $\because \because$ & 0000 \\
\hline 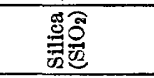 & & 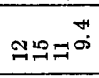 & $\therefore$ & ロロボニ \\
\hline$\dot{8} \dot{8} \dot{0} \dot{2}-1$ & & 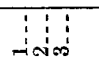 & $\begin{array}{c}5 \vdots \\
\vdots \\
4\end{array}$ & 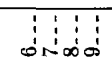 \\
\hline
\end{tabular}




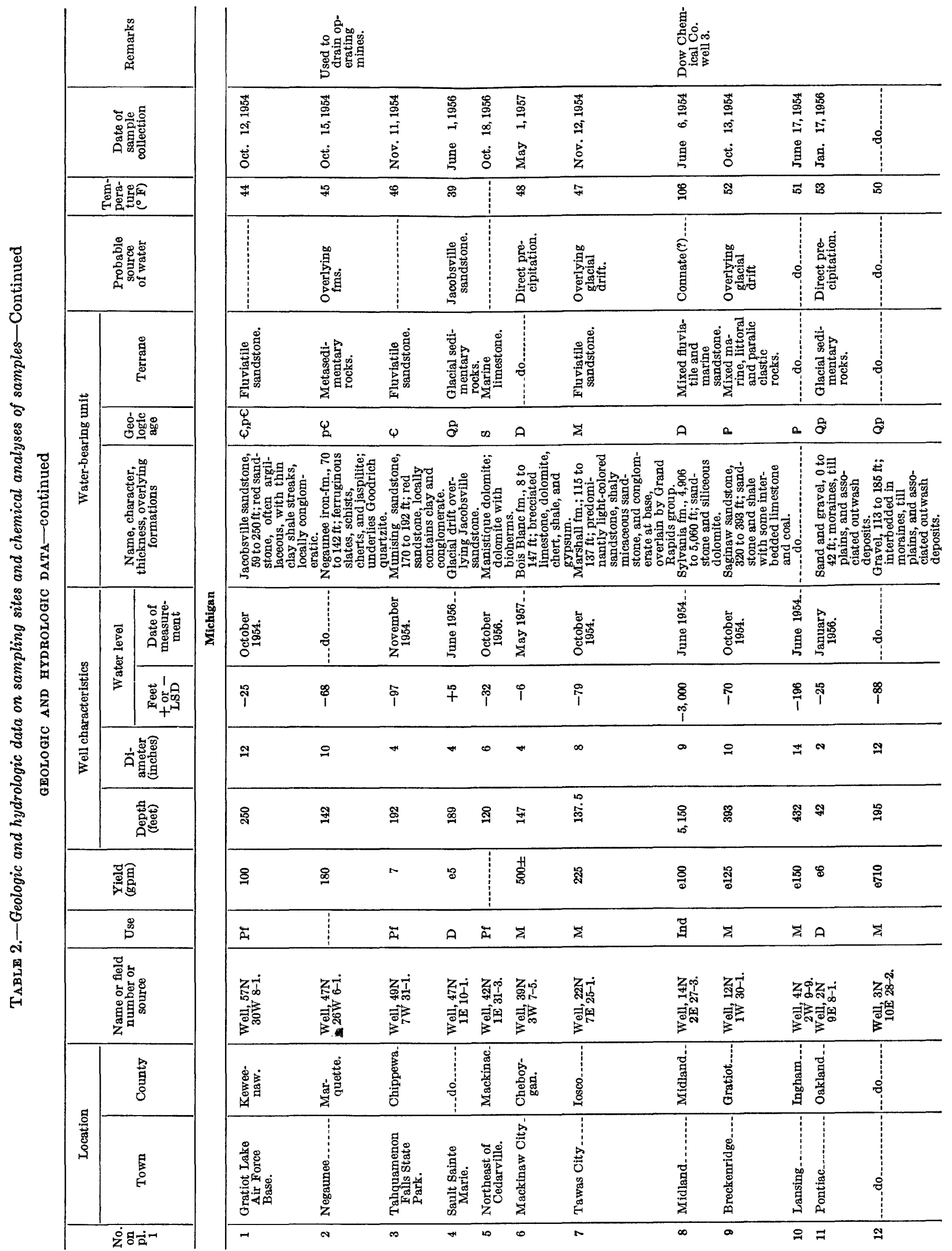


GEOLOGIC, HYDROLOGIC, AND CHEMICAL DATA
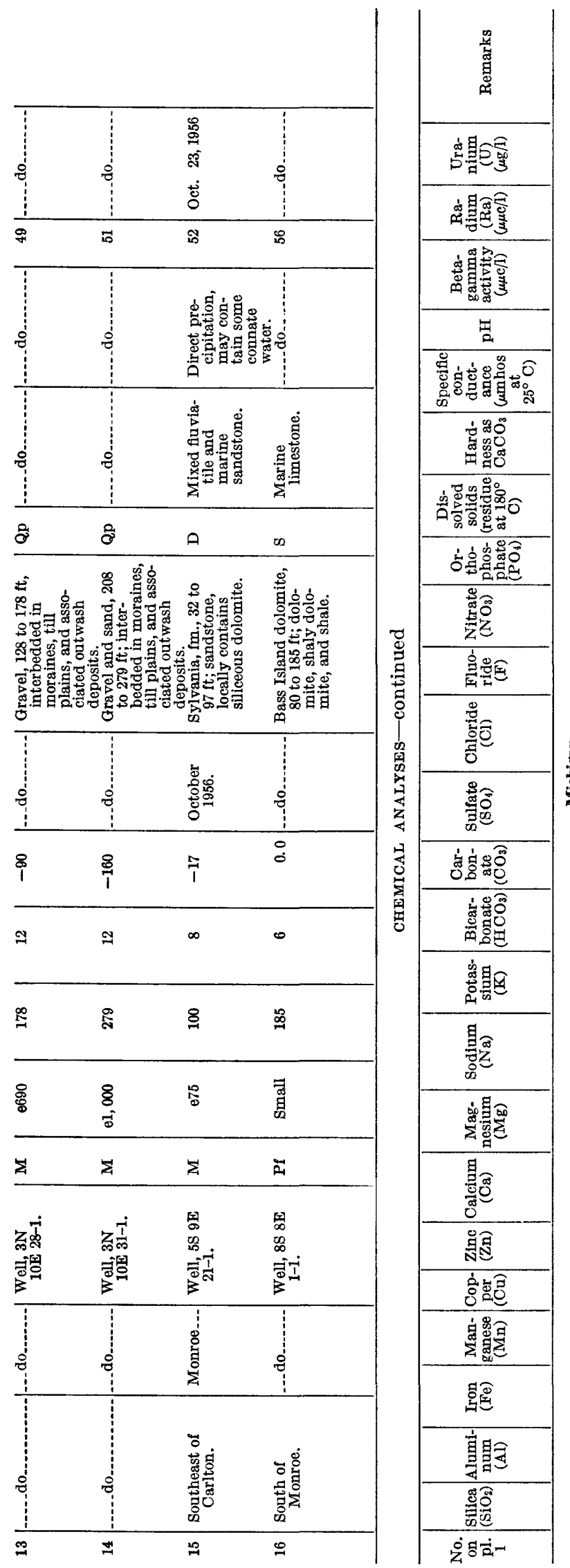

\begin{tabular}{|c|c|c|c|c|}
\hline 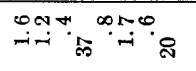 & & $m$ & 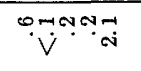 & $\underset{\infty}{\infty}$ \\
\hline 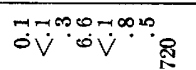 & & काष & 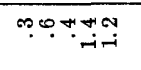 & 9 \\
\hline 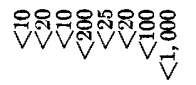 & & 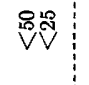 & 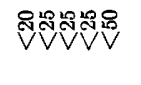 & $\stackrel{8}{\nabla}$ \\
\hline 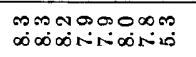 & 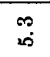 & 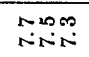 & onnomo & $\stackrel{\circ}{N}$ \\
\hline : & & f: & 跑 & 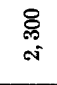 \\
\hline 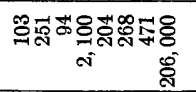 & & 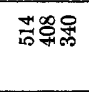 & 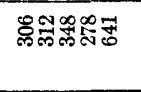 & 总 \\
\hline 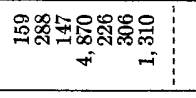 & 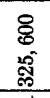 & 要: & 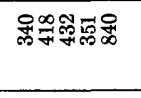 & $\begin{array}{l}\text { O } \\
\text { d } \\
\text { N }\end{array}$ \\
\hline 00.000000 & 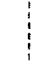 & -0 & $0.00-10$ & 0 \\
\hline - & & $\infty$ & $0,0 .-4$ & $\because$ \\
\hline 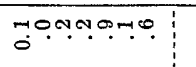 & & (ִ. & ت. & $\stackrel{\infty}{+\infty}$ \\
\hline 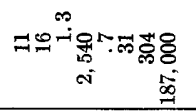 & 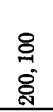 & 宓 & 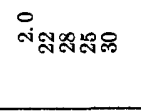 & 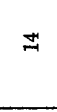 \\
\hline 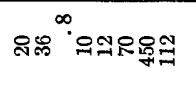 & $\stackrel{2}{\sim}$ & 암점 & 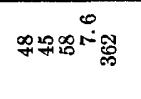 & $\underset{\sim}{\stackrel{\circ}{-1}}$ \\
\hline 00000000 & $\circ$ & 000 & 00000 & 0 \\
\hline 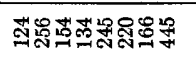 & 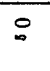 & 헣워 & 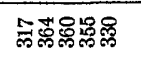 & 䒿 \\
\hline 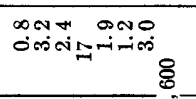 & $\begin{array}{l}\infty \\
\text { 心్ } \\
\text { o) }\end{array}$ & $\begin{array}{ll}\forall \\
i\end{array}$ & 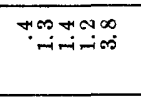 & $\infty$ \\
\hline 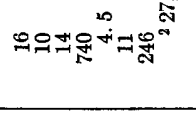 & $\begin{array}{l}8 \\
8 \\
\text { มี } \\
\end{array}$ & 80 & 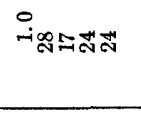 & జิ \\
\hline 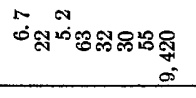 & $\begin{array}{c}\text { 索 } \\
\text { 要 } \\
\end{array}$ & 8నణ్ & స゙నాణ్ & 莽 \\
\hline 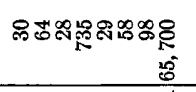 & 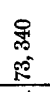 & אజ్లळ & ஜためR: & 吅 \\
\hline 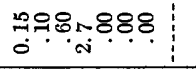 & & 8 & 8988.8 & 8 \\
\hline 8888888 & & 8 & 88888 & 8 \\
\hline 880\%8: & & $\stackrel{0}{\circ}$ & 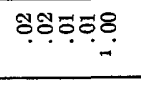 & $\ddot{0}$ \\
\hline 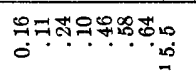 & $\tilde{ఱ}$ & (5) & क्ष. & $\stackrel{\infty}{i}$ \\
\hline ONN & 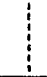 & $=$ & 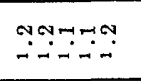 & $\stackrel{\infty}{-}$ \\
\hline 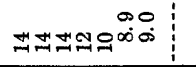 & $\Xi$ & 요ㄱㅛㅠ & ロロニロロニ & 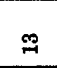 \\
\hline TNM tru & & 90 & 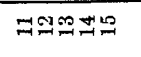 & 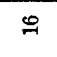 \\
\hline
\end{tabular}




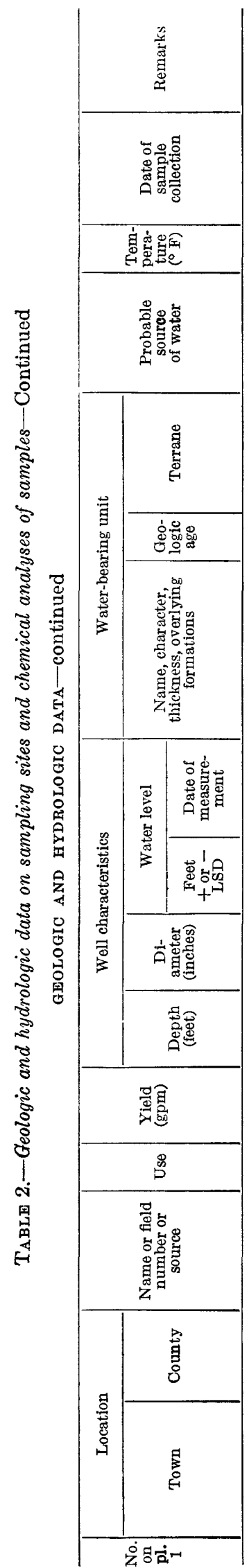

\begin{tabular}{|c|c|c|c|c|c|c|c|c|c|}
\hline 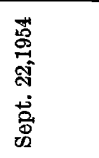 & 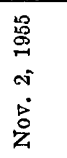 & 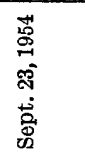 & : & 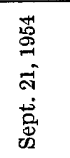 & $\begin{array}{l}\text { 总 } \\
\text { क } \\
\infty \\
\dot{0} \\
\dot{0}\end{array}$ & 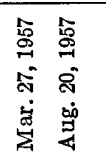 & 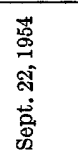 & 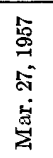 & 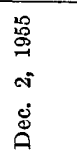 \\
\hline i & $\mathscr{T}$ & 70 & $\overrightarrow{5}$ & $\overline{10}$ & $\ddot{n}$ & 8 is & 80 & $\overrightarrow{6}$ & F \\
\hline & 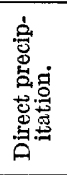 & 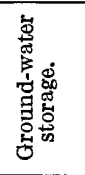 & 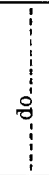 & 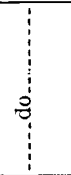 & 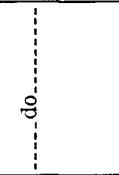 & 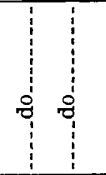 & $\stackrel{1}{\square}$ & 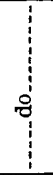 & 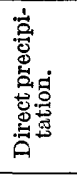 \\
\hline 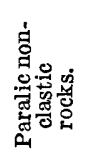 & 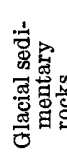 & 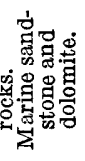 & 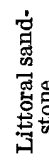 & 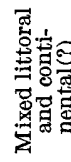 & 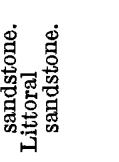 & 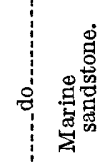 & 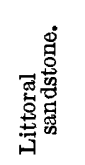 & 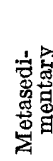 & 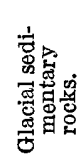 \\
\hline$\stackrel{\varphi}{\sharp}$ & वै & $\stackrel{\circ}{\dot{\phi}}$ & $\varphi$ & $\dot{\varphi}$ & $\forall$ & $\forall \forall$ & $\varphi$ & $\underline{L}$ & 8 \\
\hline 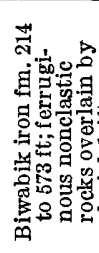 & 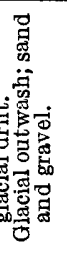 & 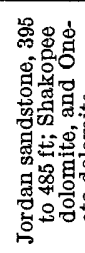 & 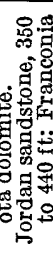 & 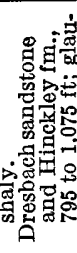 & 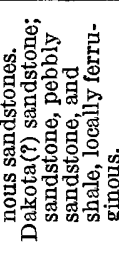 & 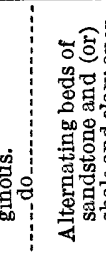 & 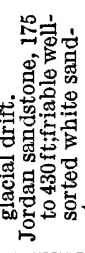 & 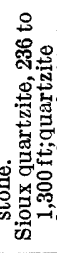 & 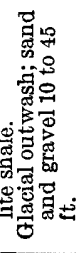 \\
\hline 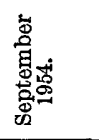 & 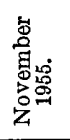 & & & & 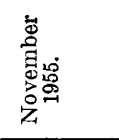 & 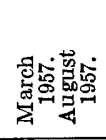 & & 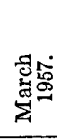 & 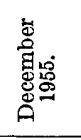 \\
\hline 留 & $\uparrow$ & & & $:$ & $\frac{8}{1}$ & 异 & & $\stackrel{i}{1}$ & $\frac{\pi}{1}$ \\
\hline 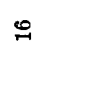 & $\Im$ & 壱 & \& & $\cong$ & $\mathscr{q}$ & 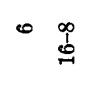 & 8 & $\cong$ & $\mathscr{\infty}$ \\
\hline 搹 & 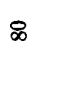 & 多 & ळ & $\stackrel{\mathscr{0}}{\stackrel{\mathscr{B}}{-}}$ & \$ & 品 喿 & 桑 & 品 & 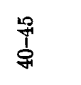 \\
\hline \% & \&્ఠ & 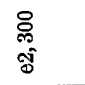 & 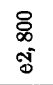 & 웅 & 号 & 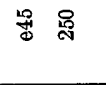 & \& & $\frac{8}{90}$ & 兽 \\
\hline$\Sigma$ & $ت$ & $\mathrm{z}$ & $\ddot{0.0}$ & 草 & 芒 & $\Sigma \Sigma$ & 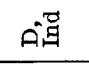 & $\Sigma$ & $\Sigma$ \\
\hline 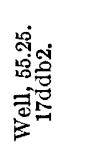 & 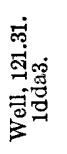 & 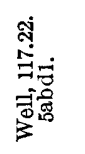 & 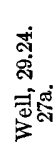 & 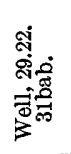 & 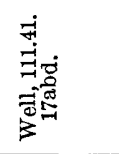 & 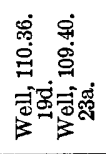 & 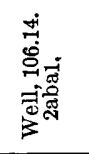 & 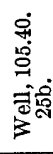 & 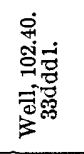 \\
\hline 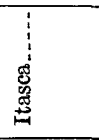 & 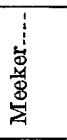 & 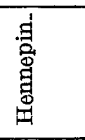 & 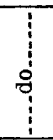 & 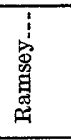 & 总 & 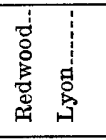 & 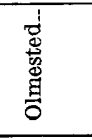 & 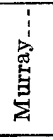 & $\begin{array}{r}\vdots \\
\vdots \\
3 \\
30 \\
3 \\
3\end{array}$ \\
\hline 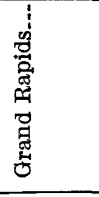 & 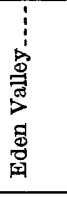 & 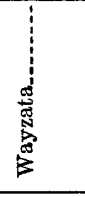 & 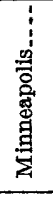 & 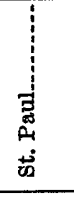 & 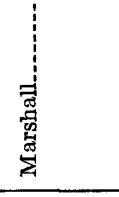 & 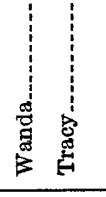 & $\begin{array}{l}\text { 密 } \\
\text { 总 } \\
\text { 品 } \\
\end{array}$ & 章 & 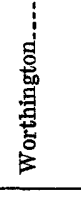 \\
\hline- & $N$ & $\infty$ & + & 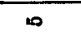 & 0 & $\sim \infty$ & $\infty$ & 8 & 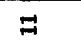 \\
\hline
\end{tabular}




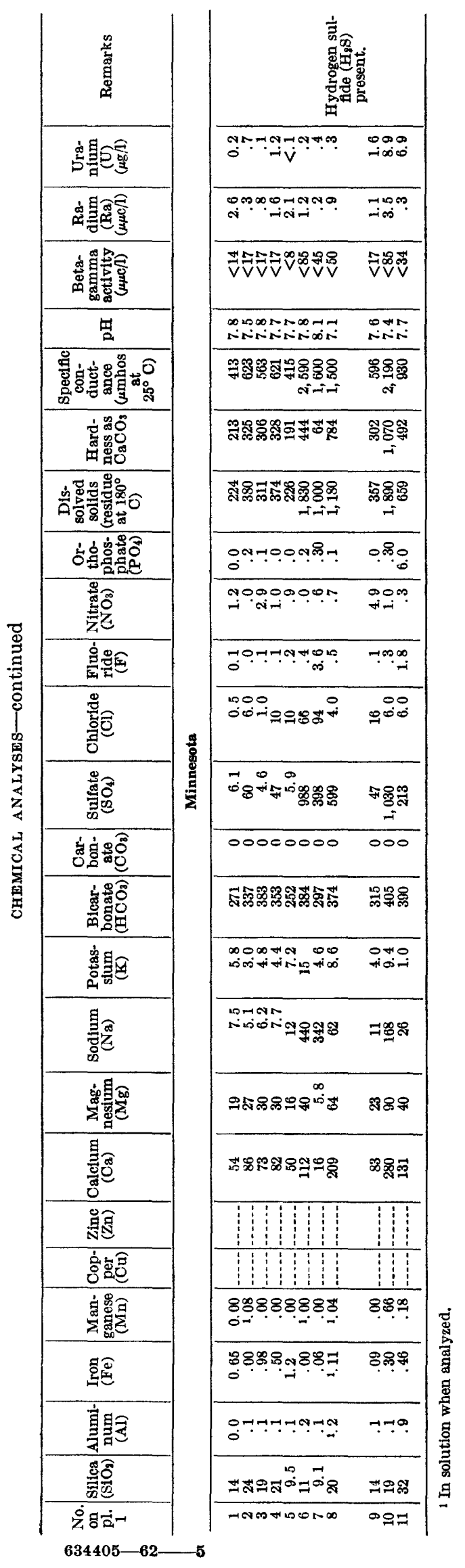




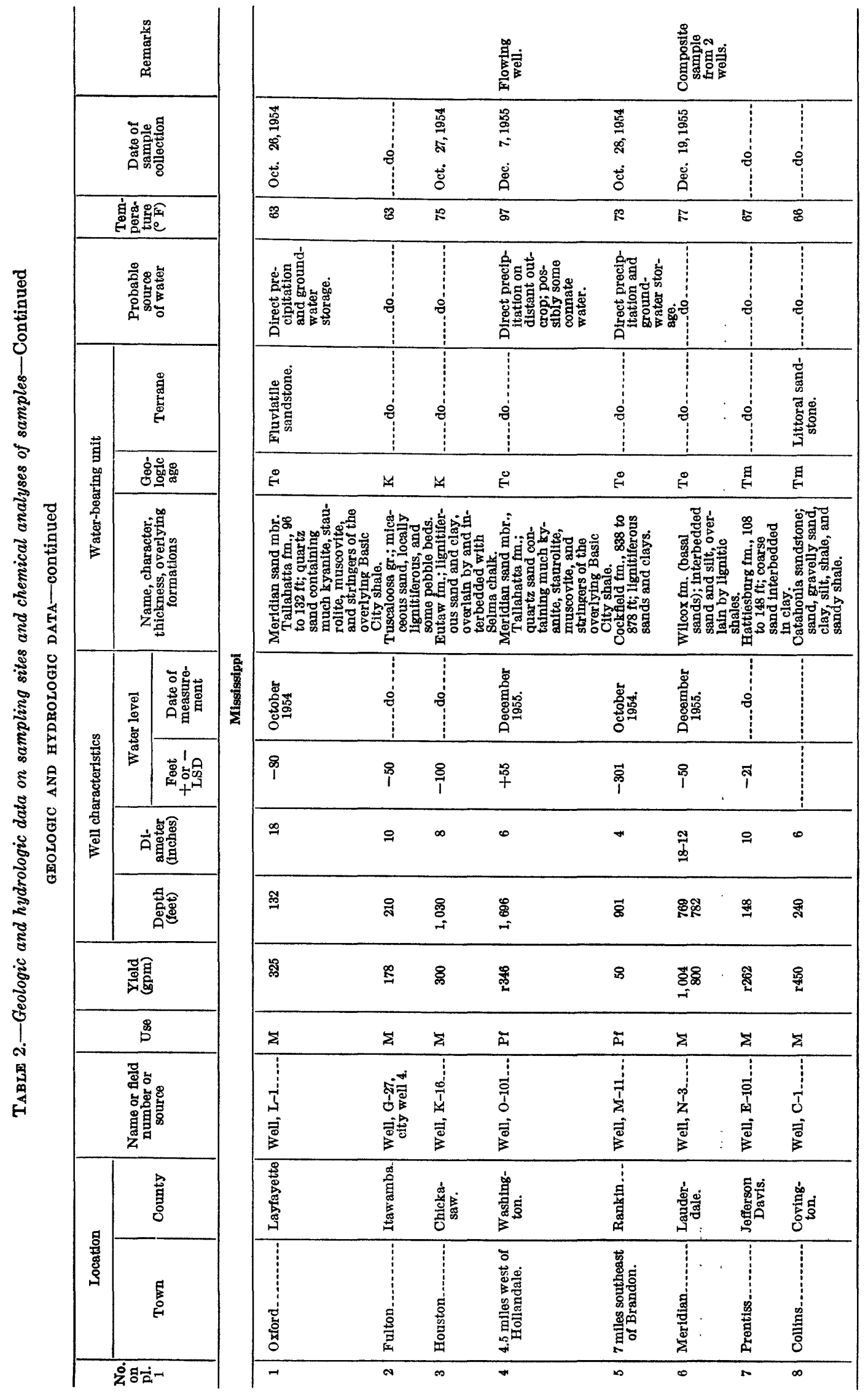




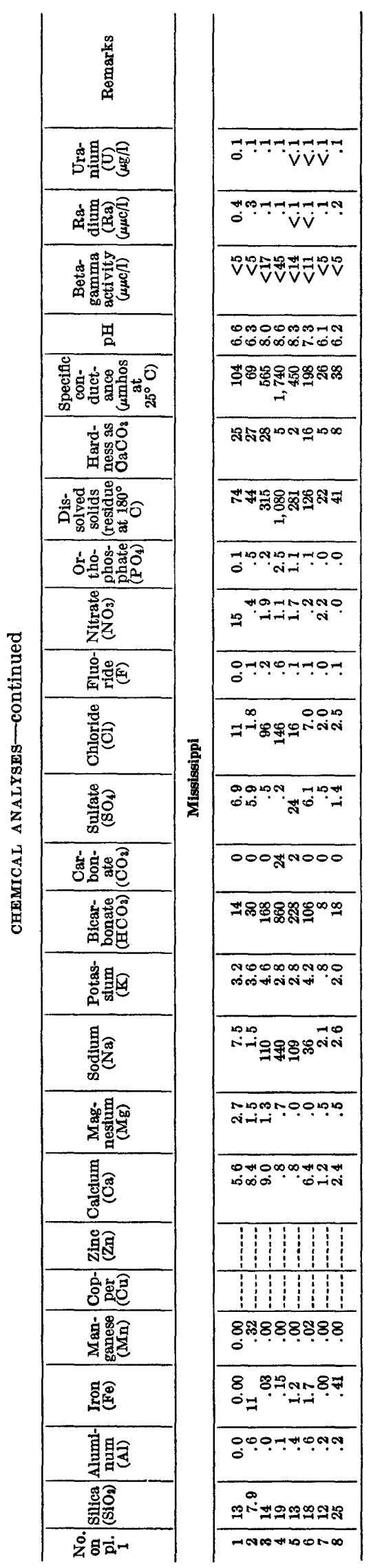




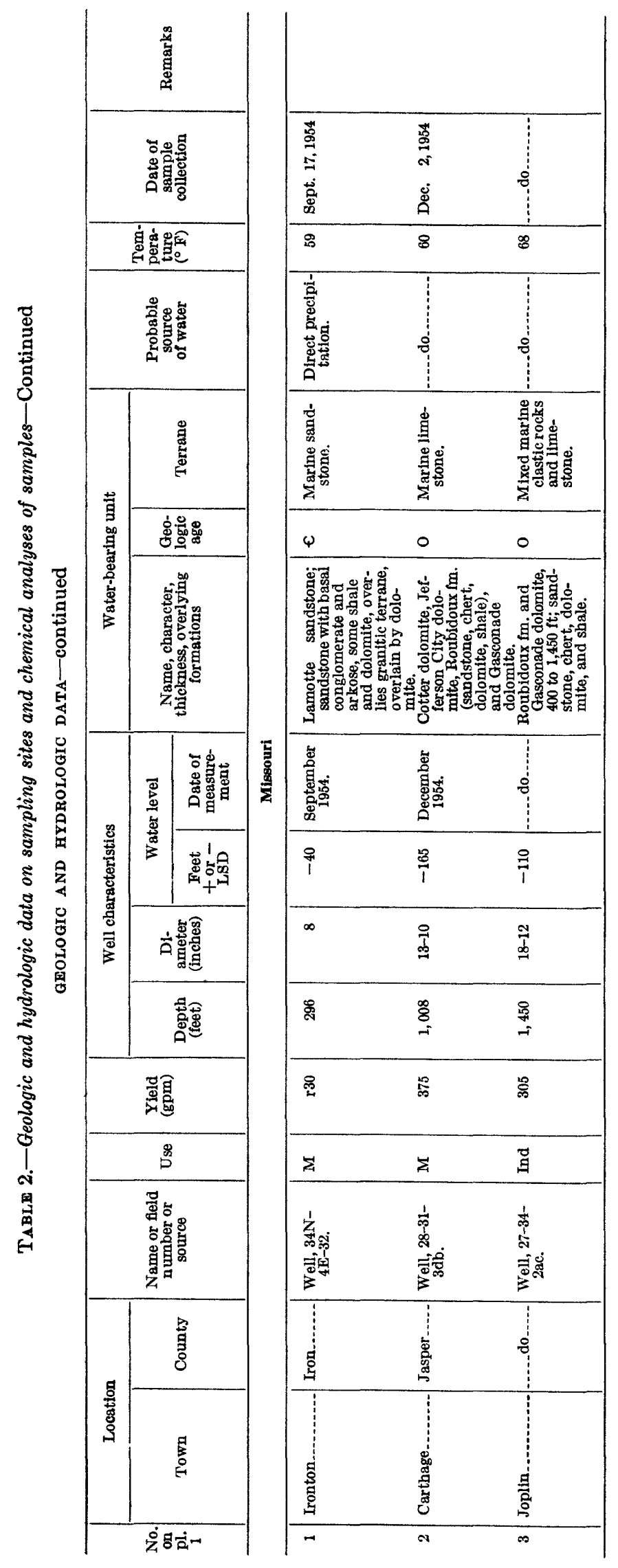


GEOLOGIC, HYDROLOGIC, AND CHEMICAL DATA

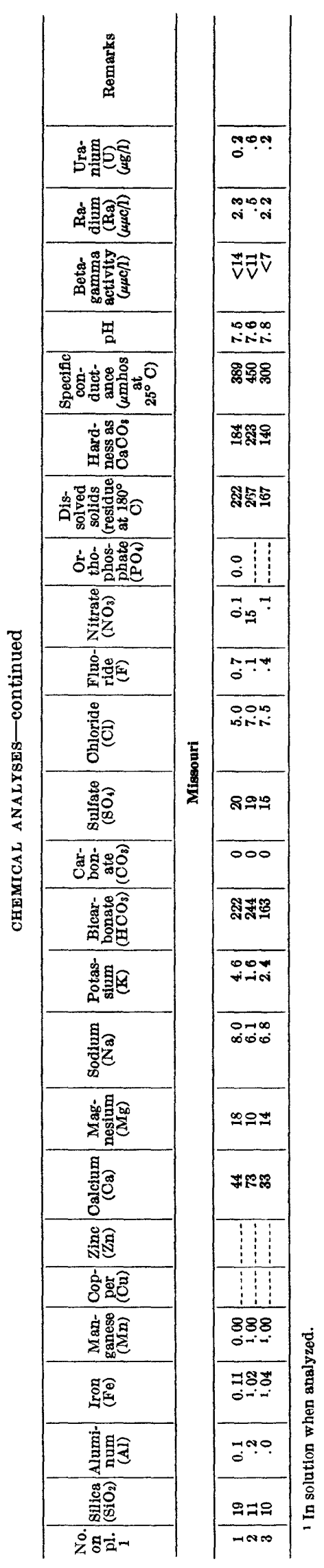


DATA ON URANIUM AND RADIUM IN GROUND WATER IN UNITED STATES, 1954 TO 1957

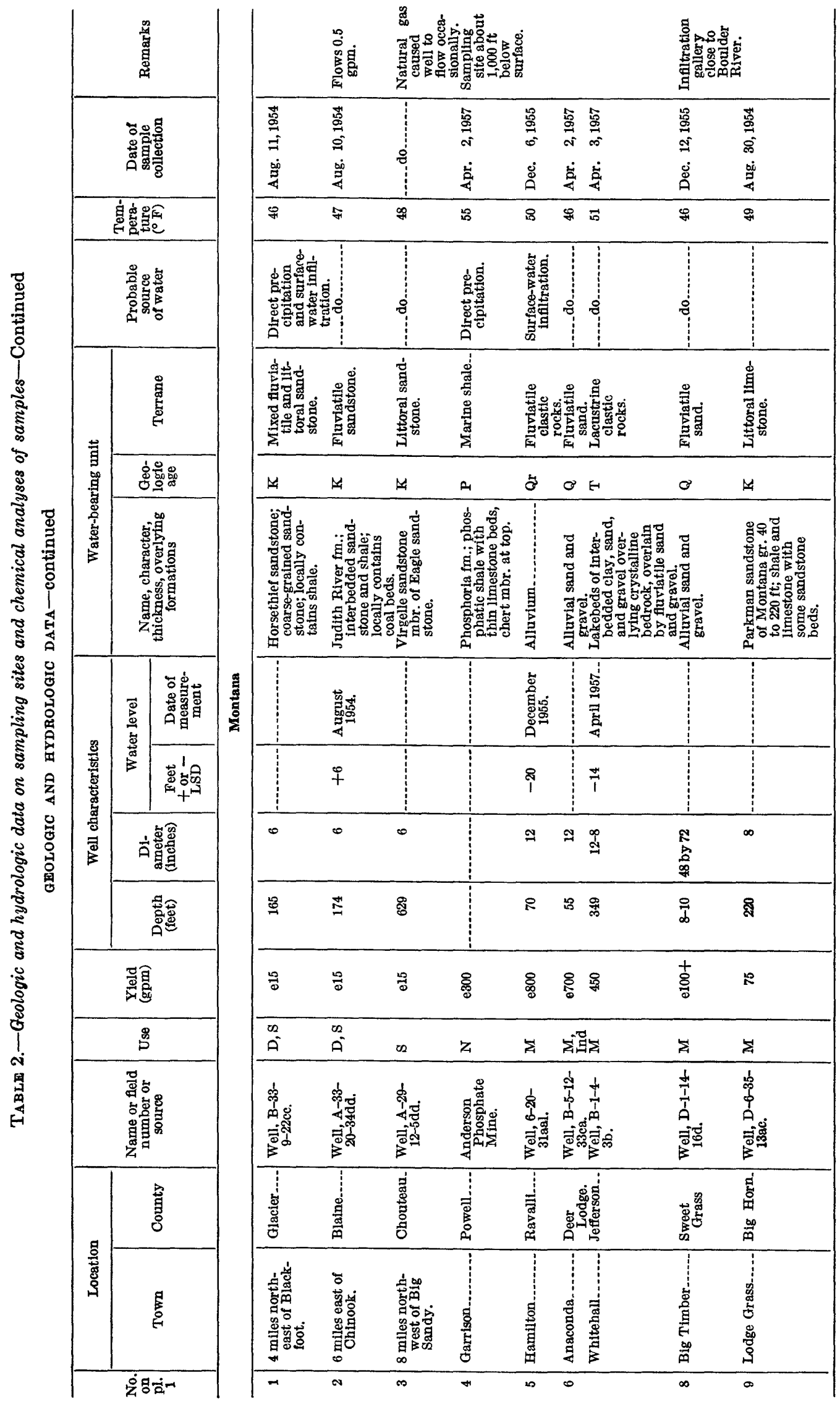




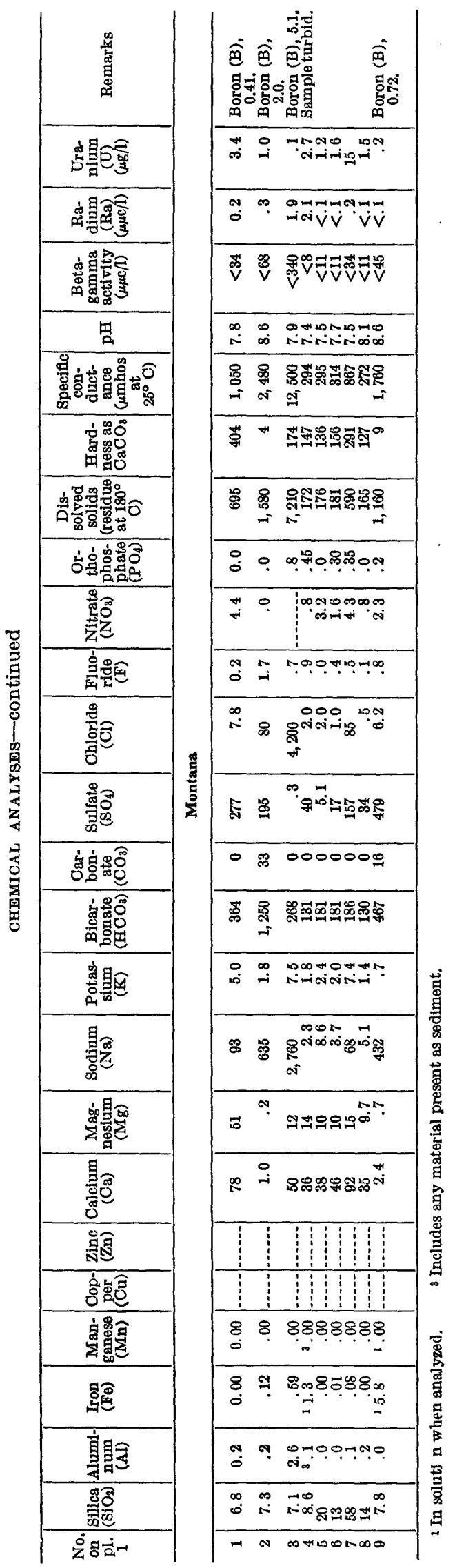




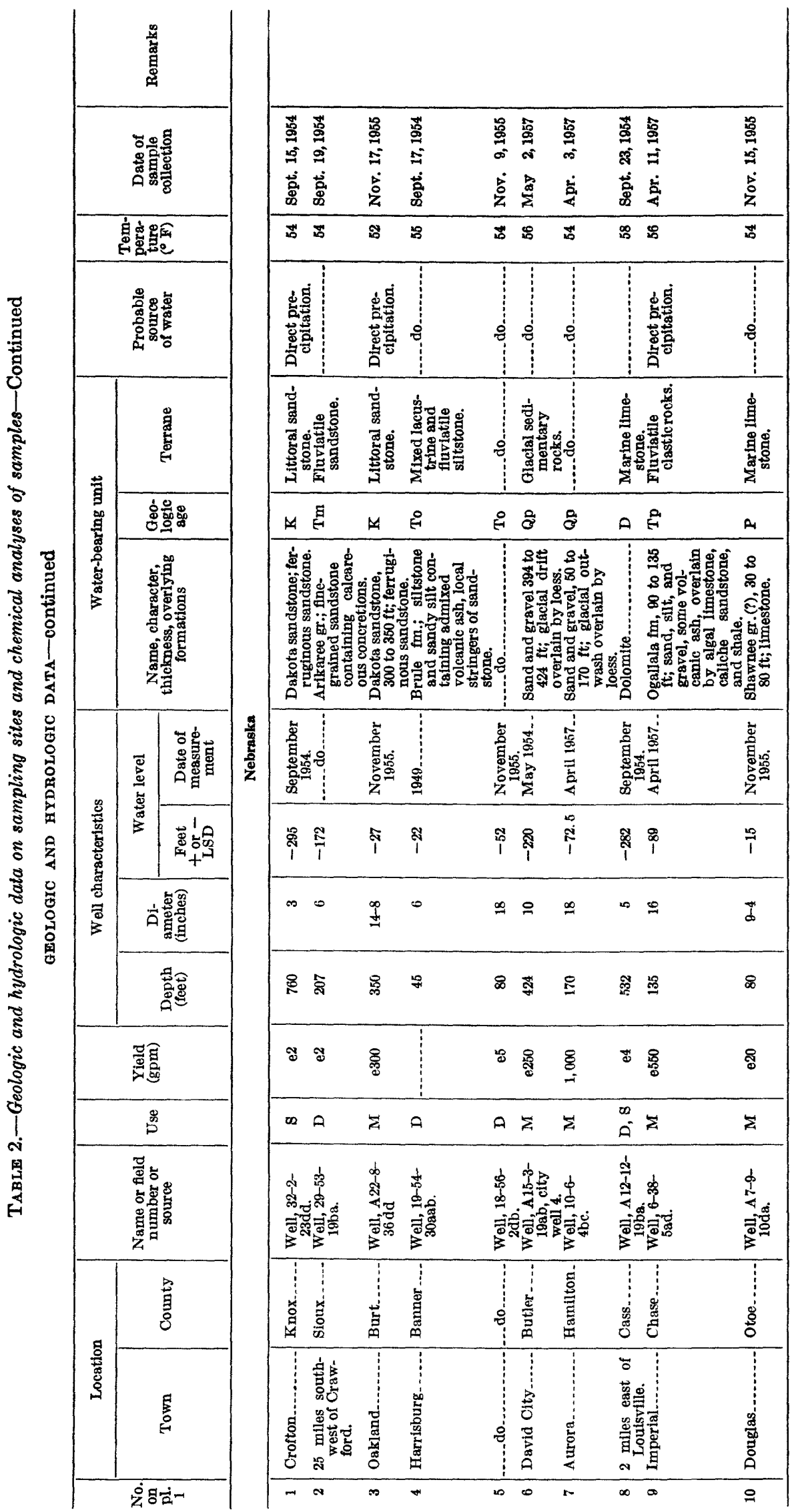


GEOLOGIC, HYDROLOGIC, AND CHEMICAL DATA

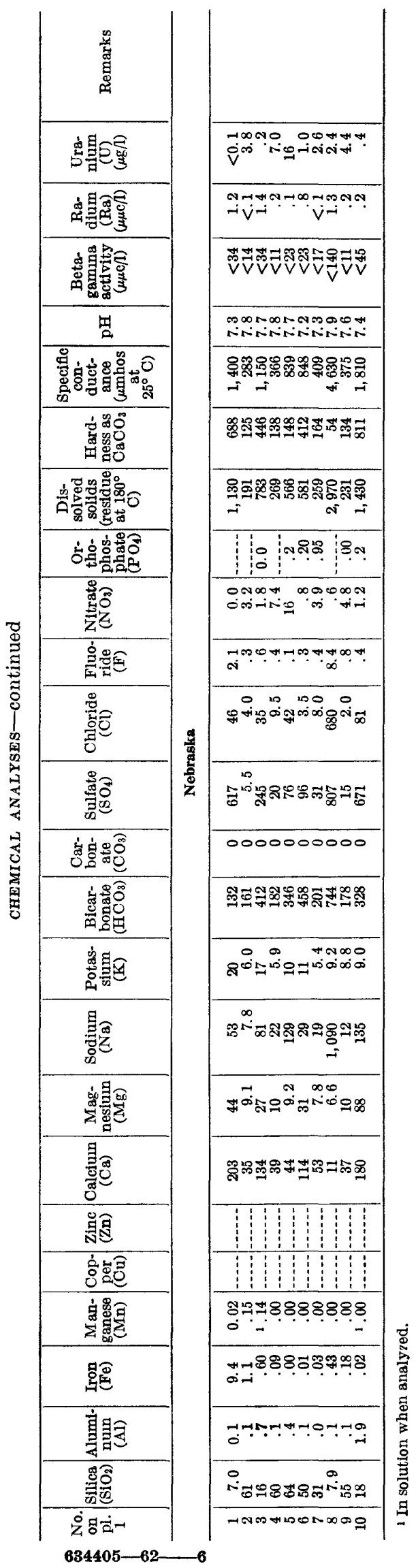




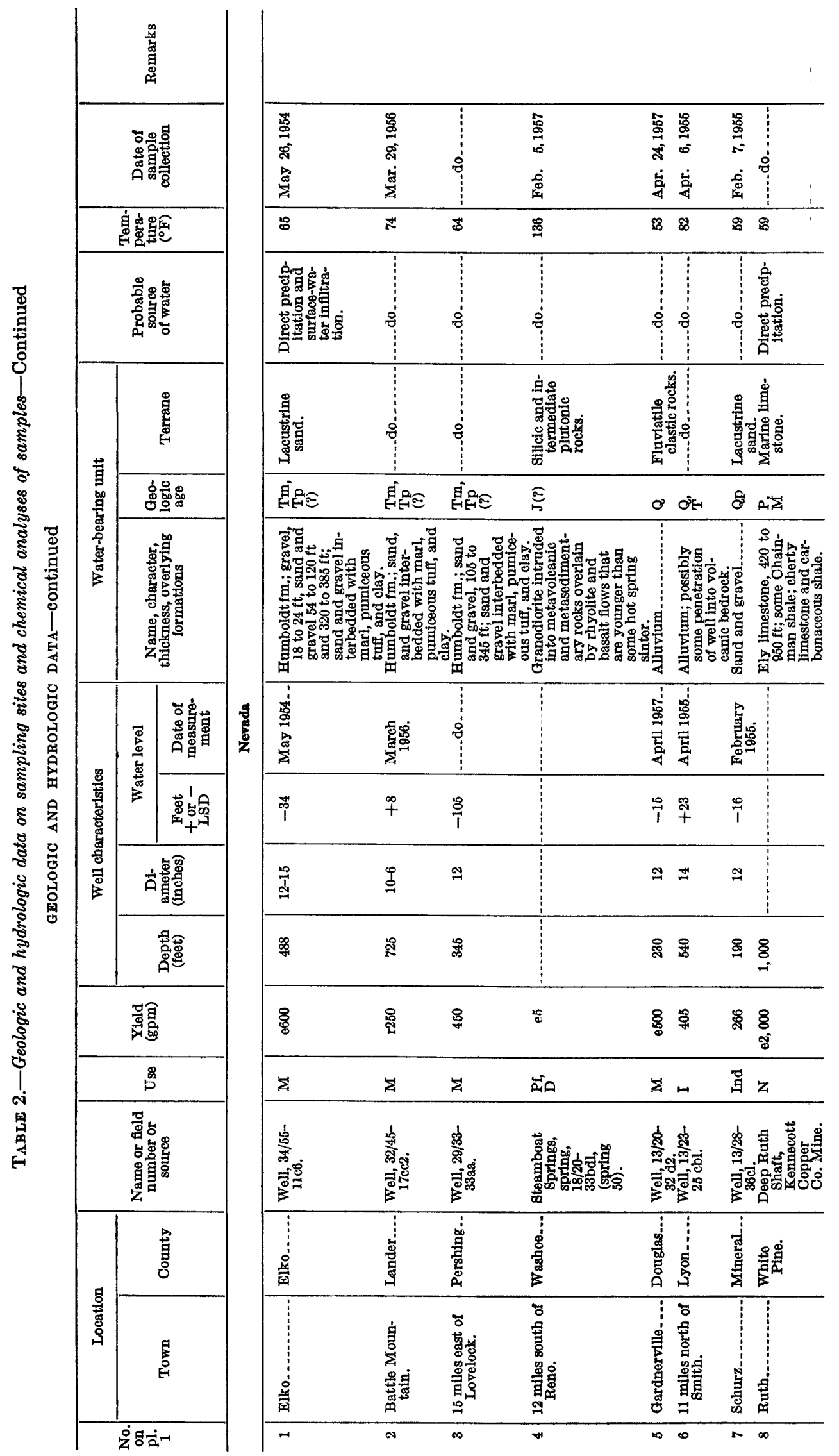



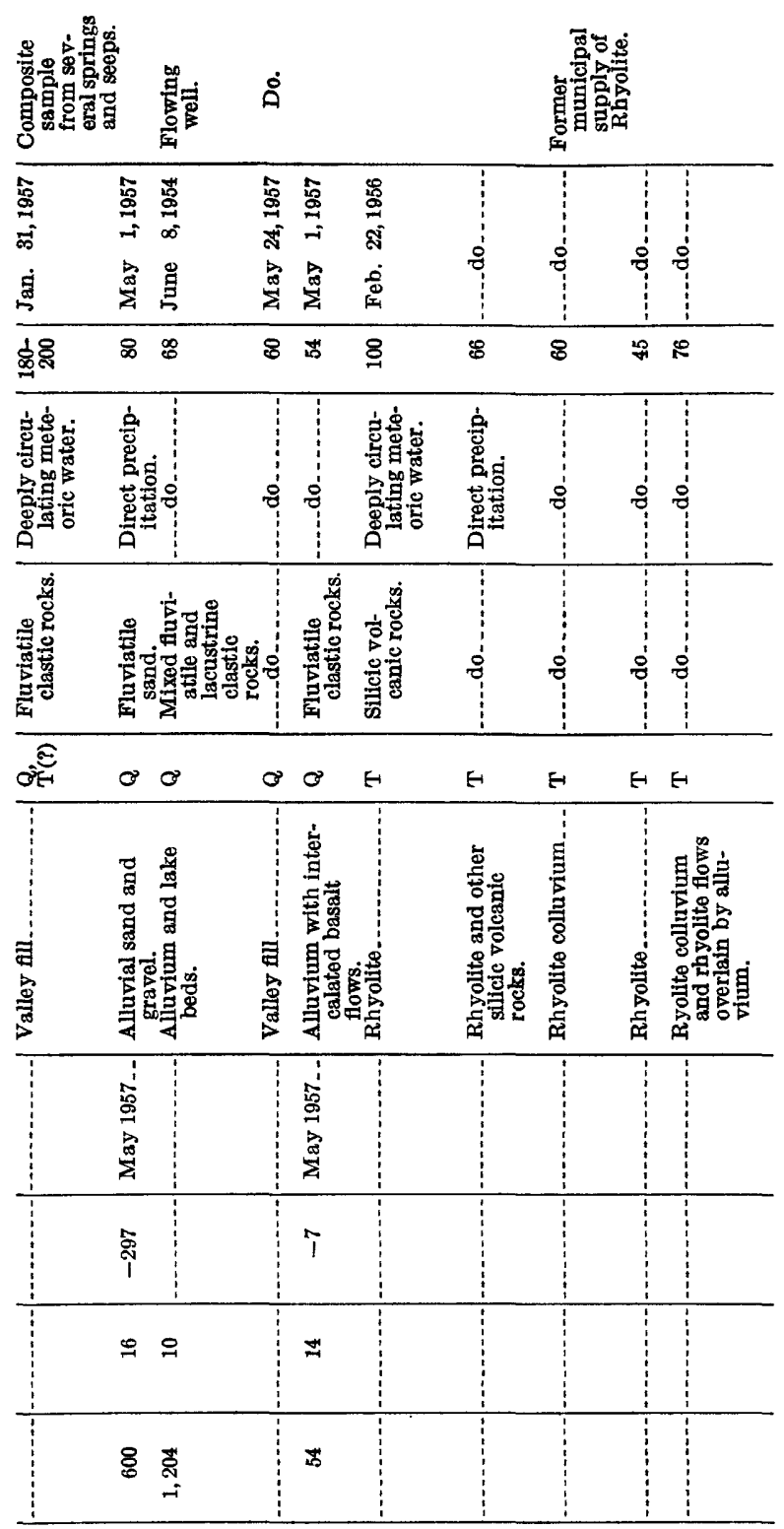

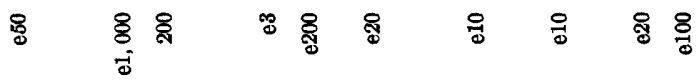

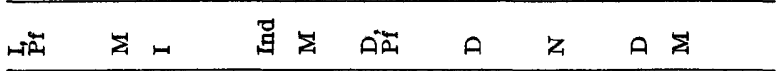
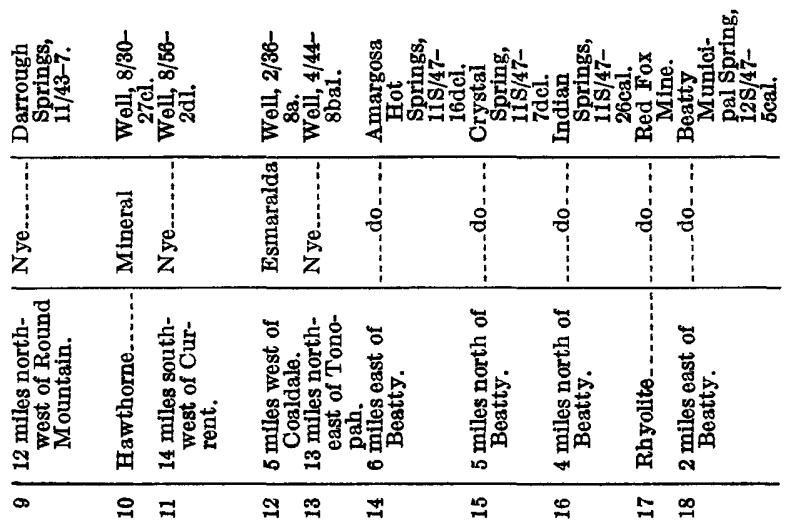

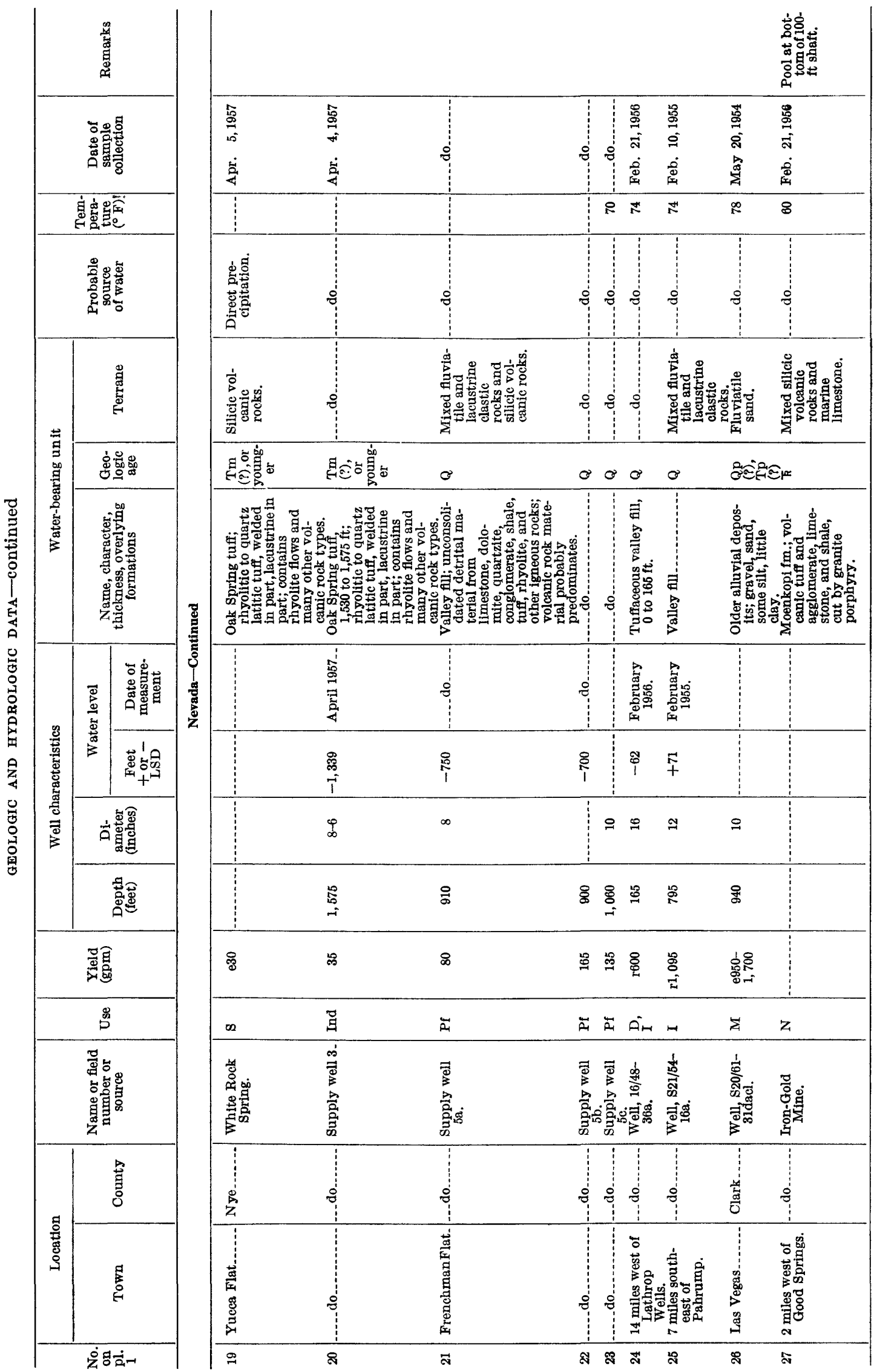
GEOLOGIC, HYDROLOGIC, AND CHEMICAL DATA

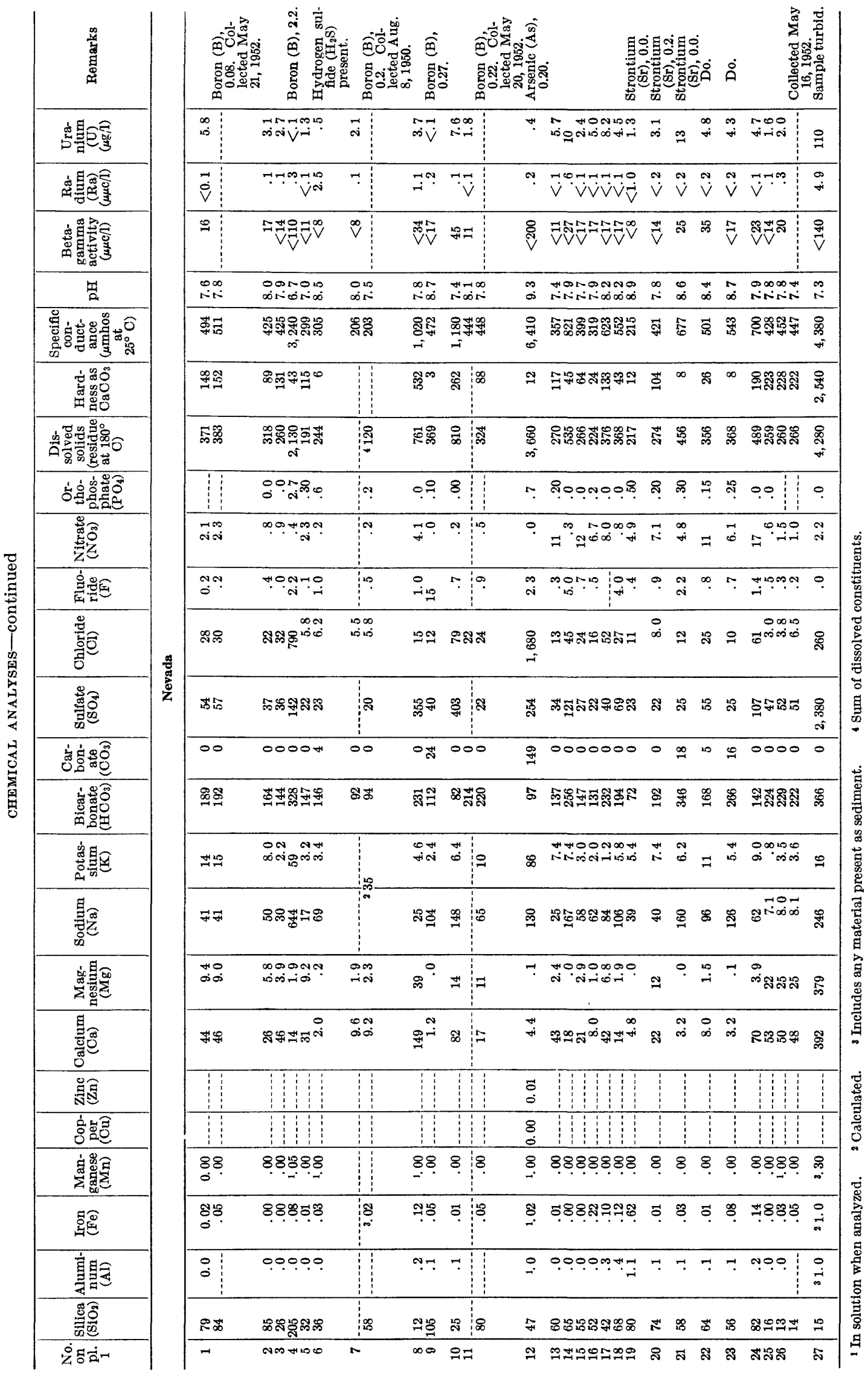


DATA ON URANIUM AND RADIUM IN GROUND WATER IN UNITED STATES, 1954 TO 1957

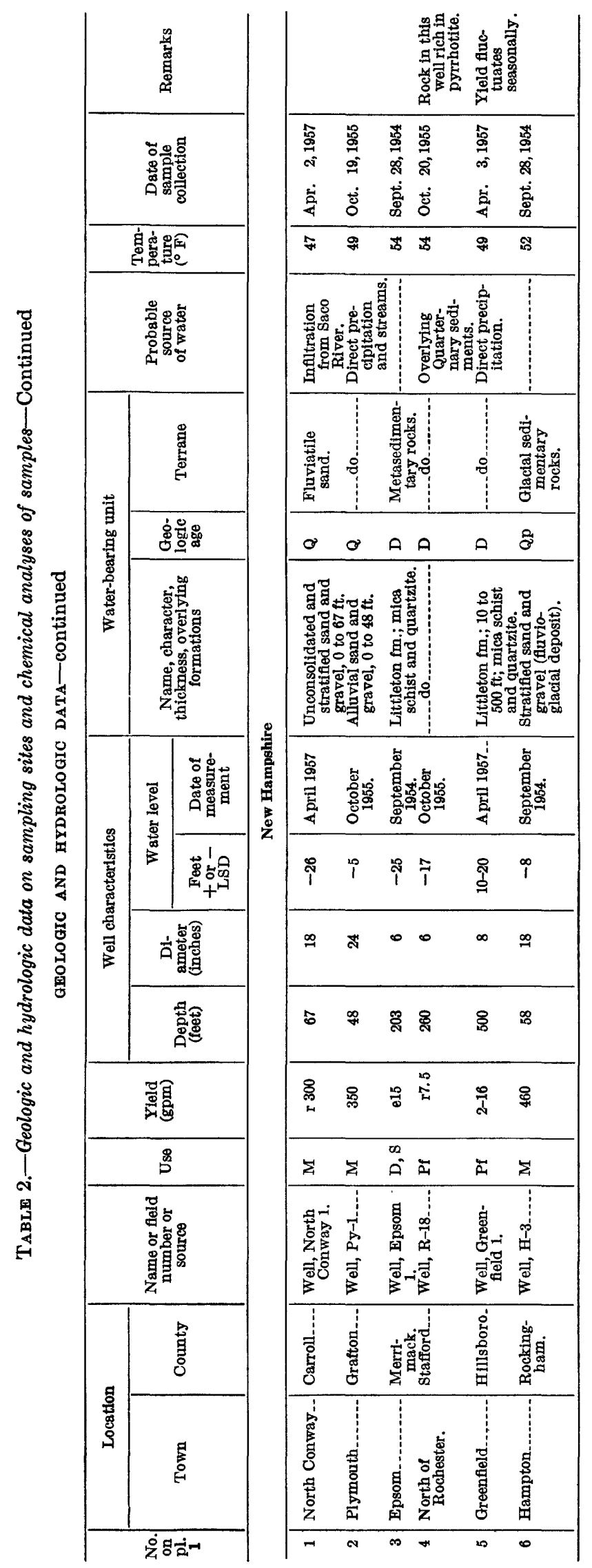


GEOLOGIC, HXDROLOGIC, AND CHEMICAL DATA

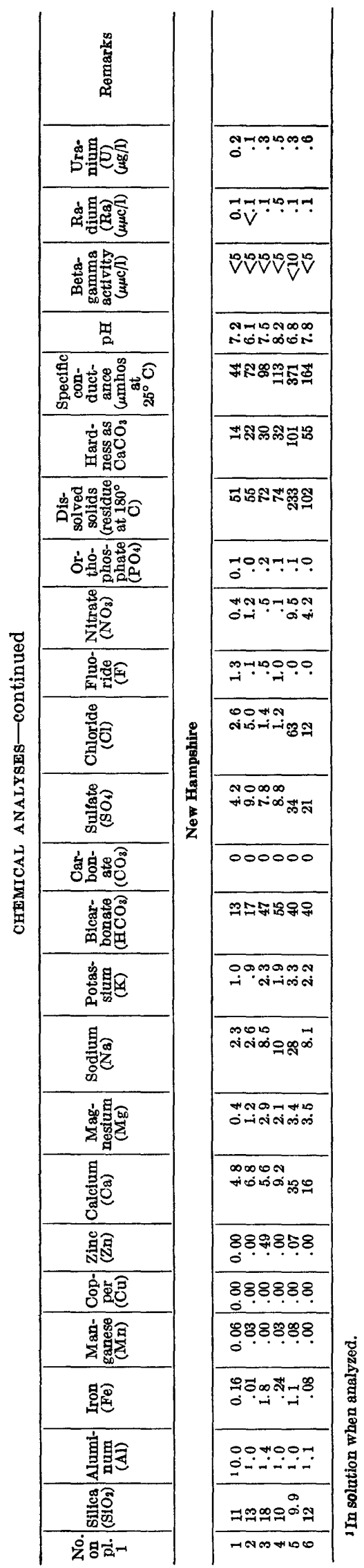




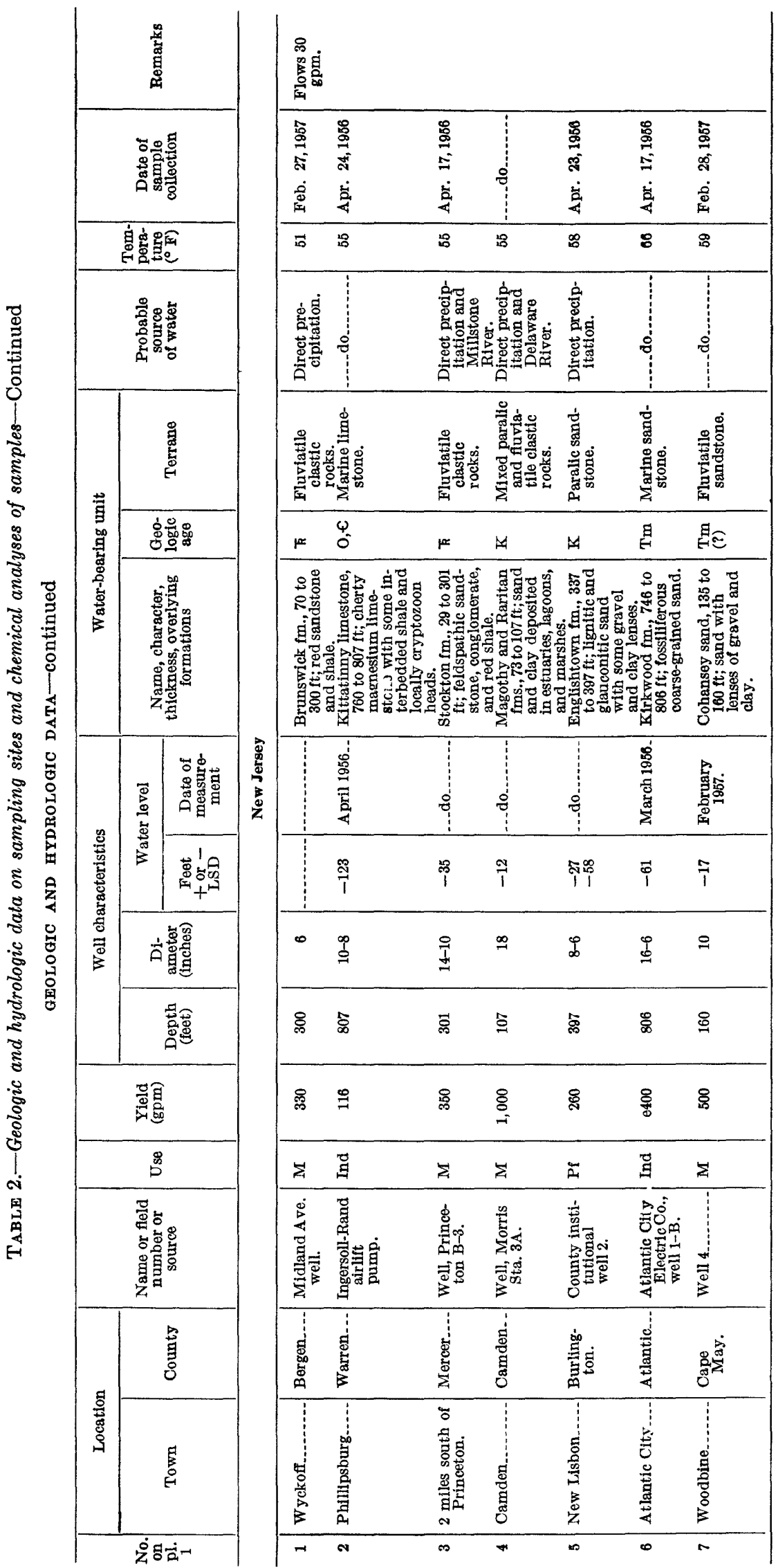



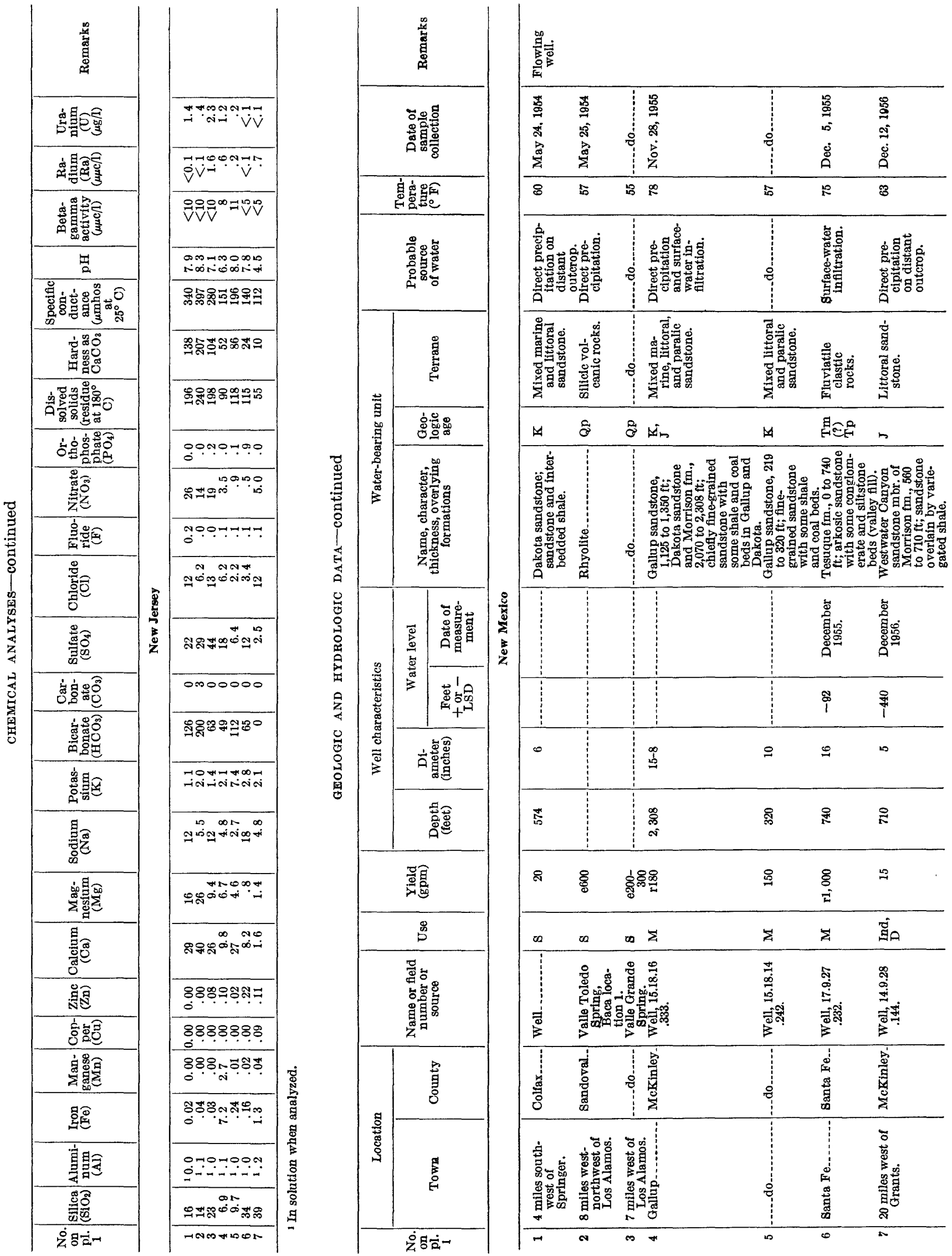


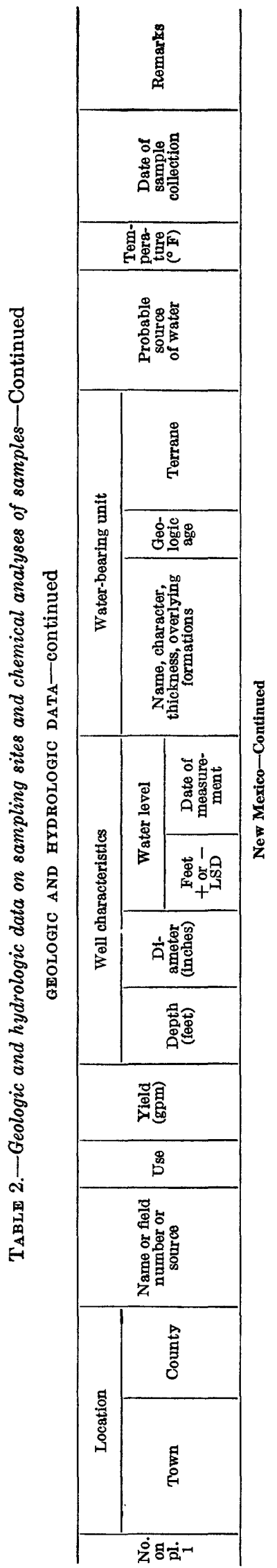

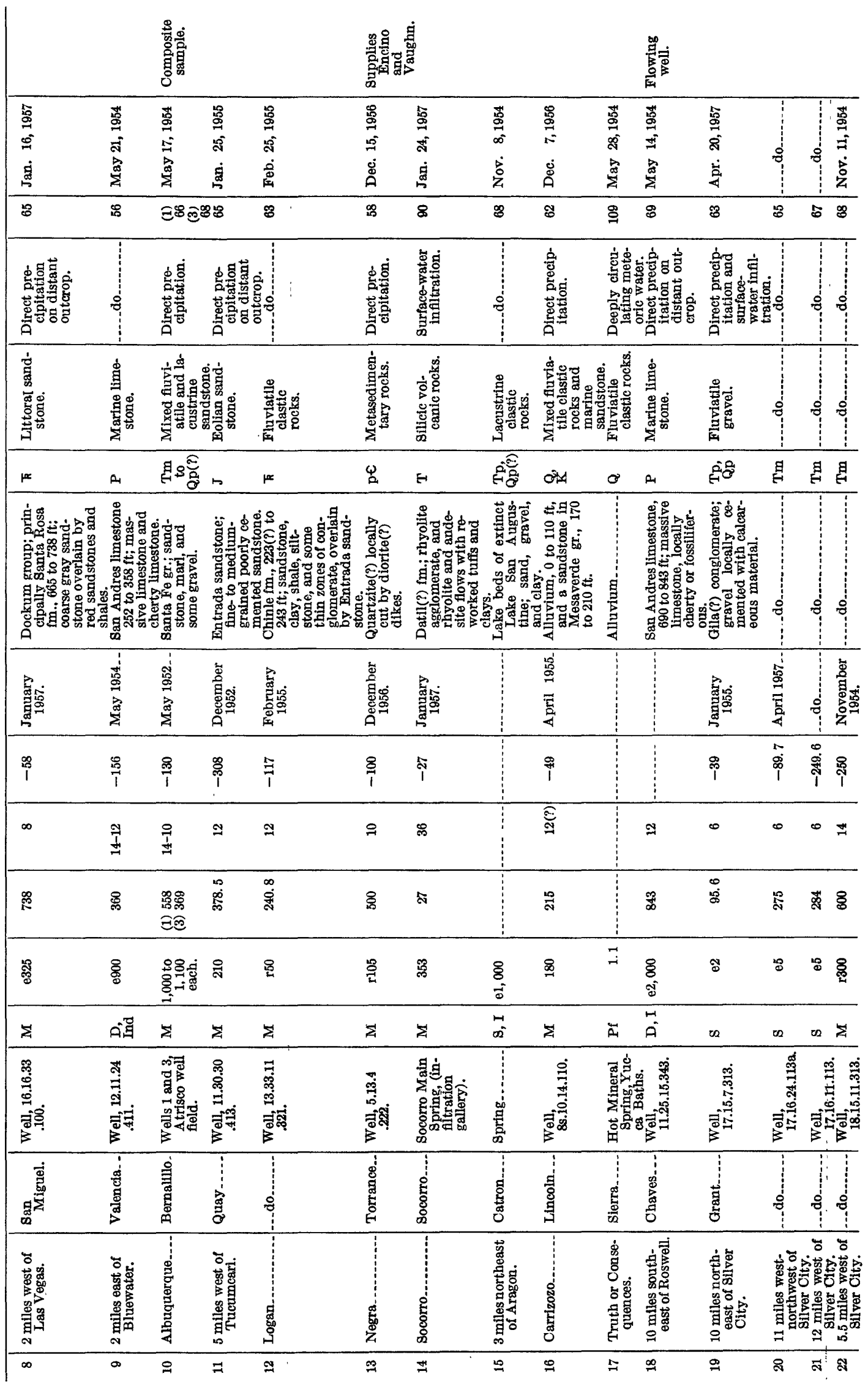


GEOLOGIC, HYDROLOGIC, AND CHEMICAL DATA

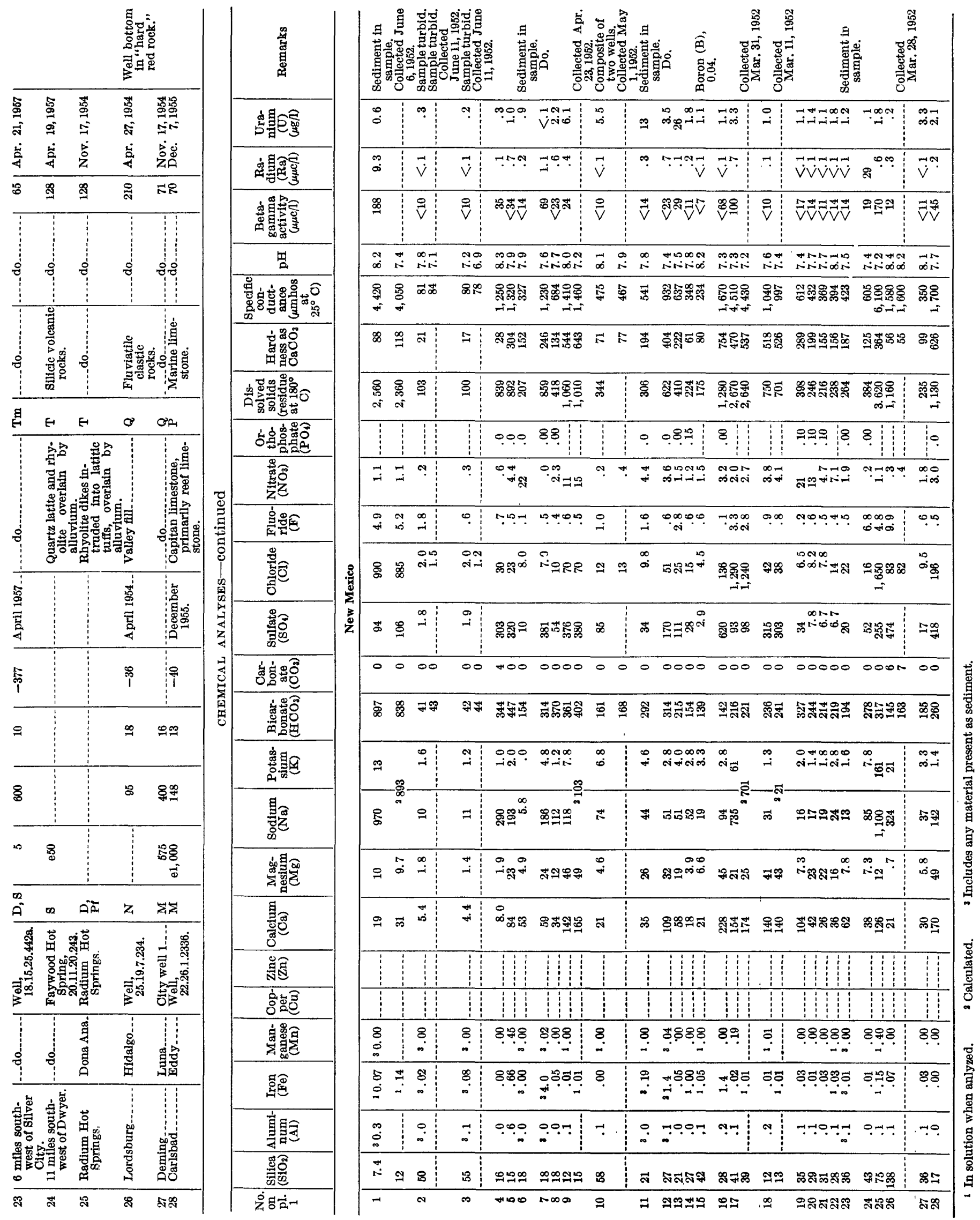




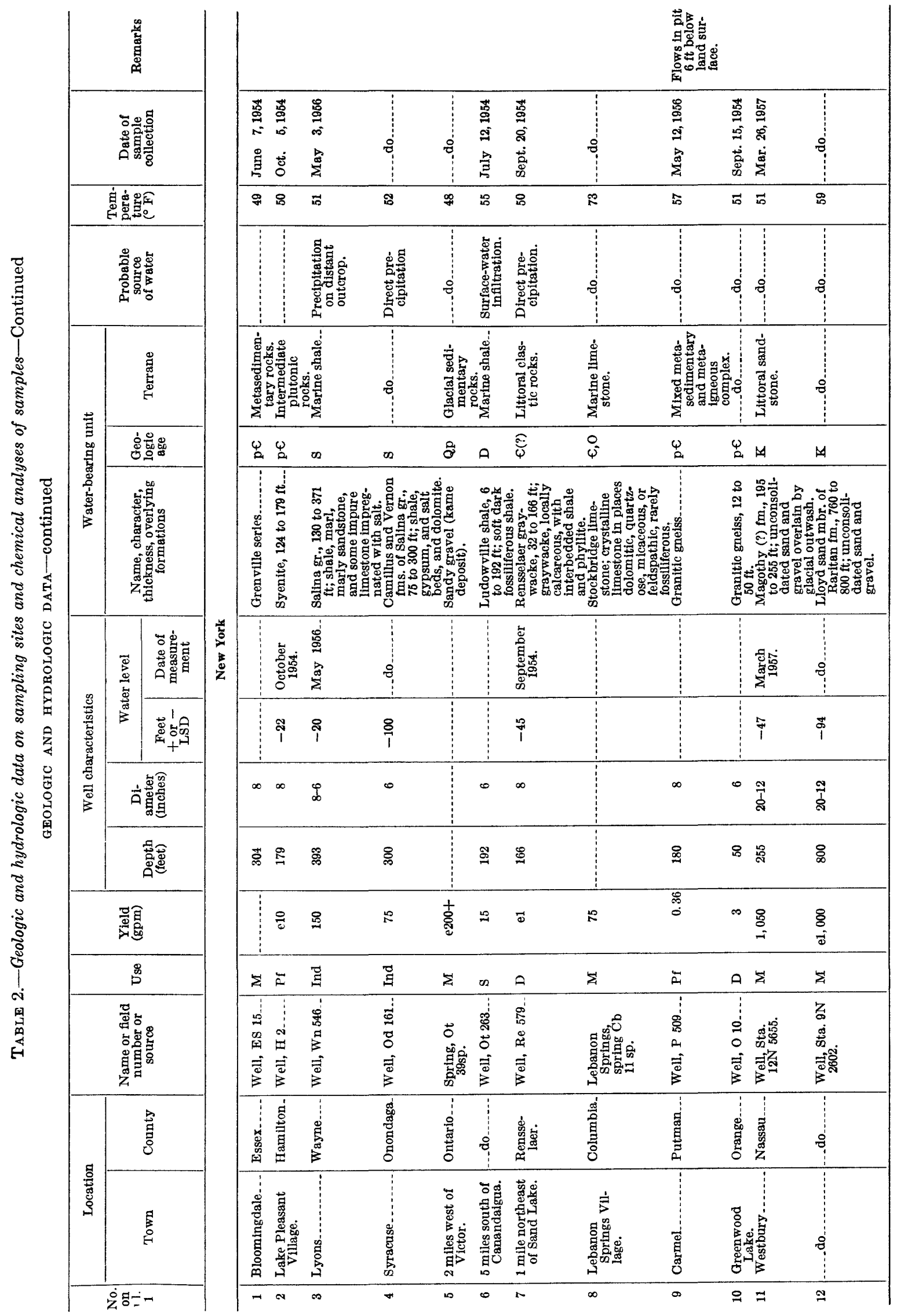


GEOLOGIC, HYDROLOGIC, AND CHEMICAL DATA

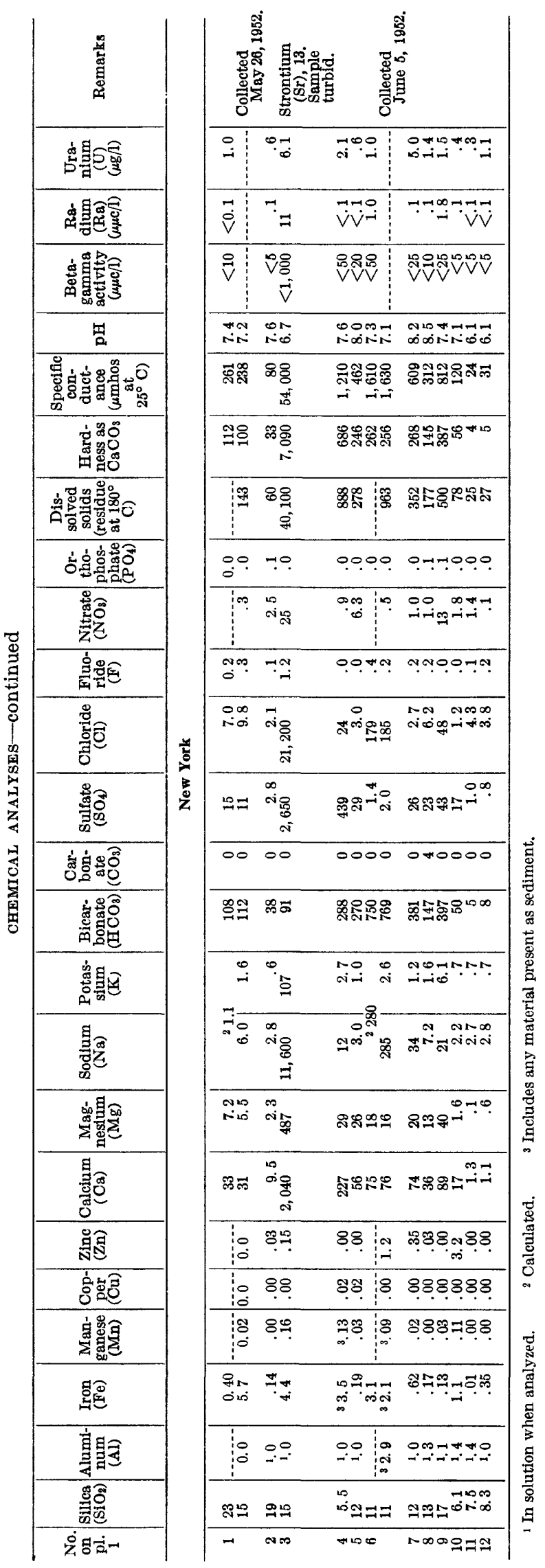




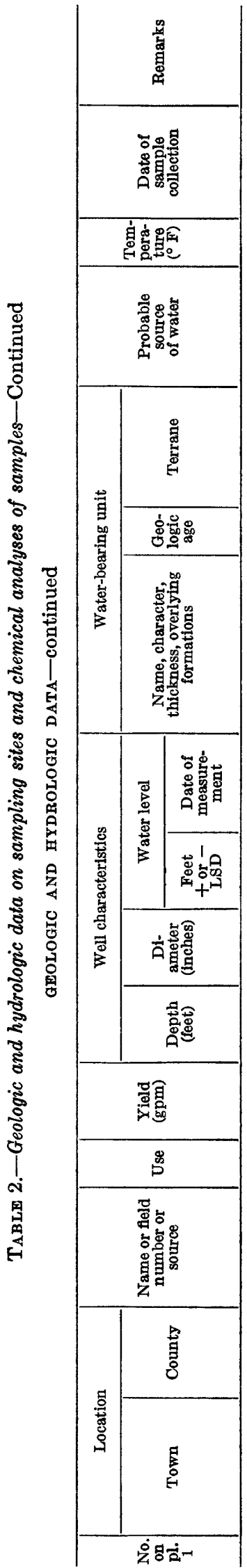

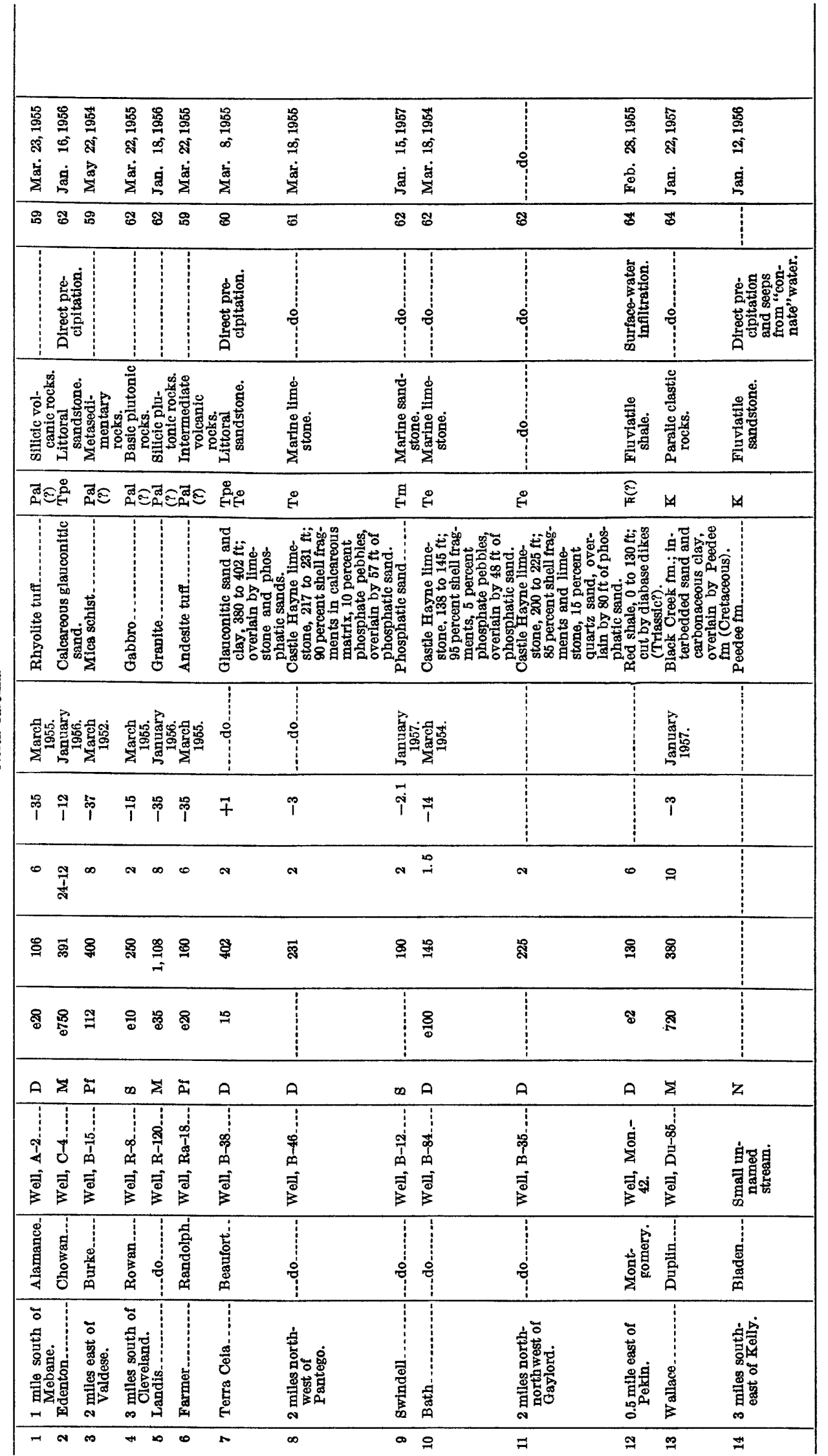




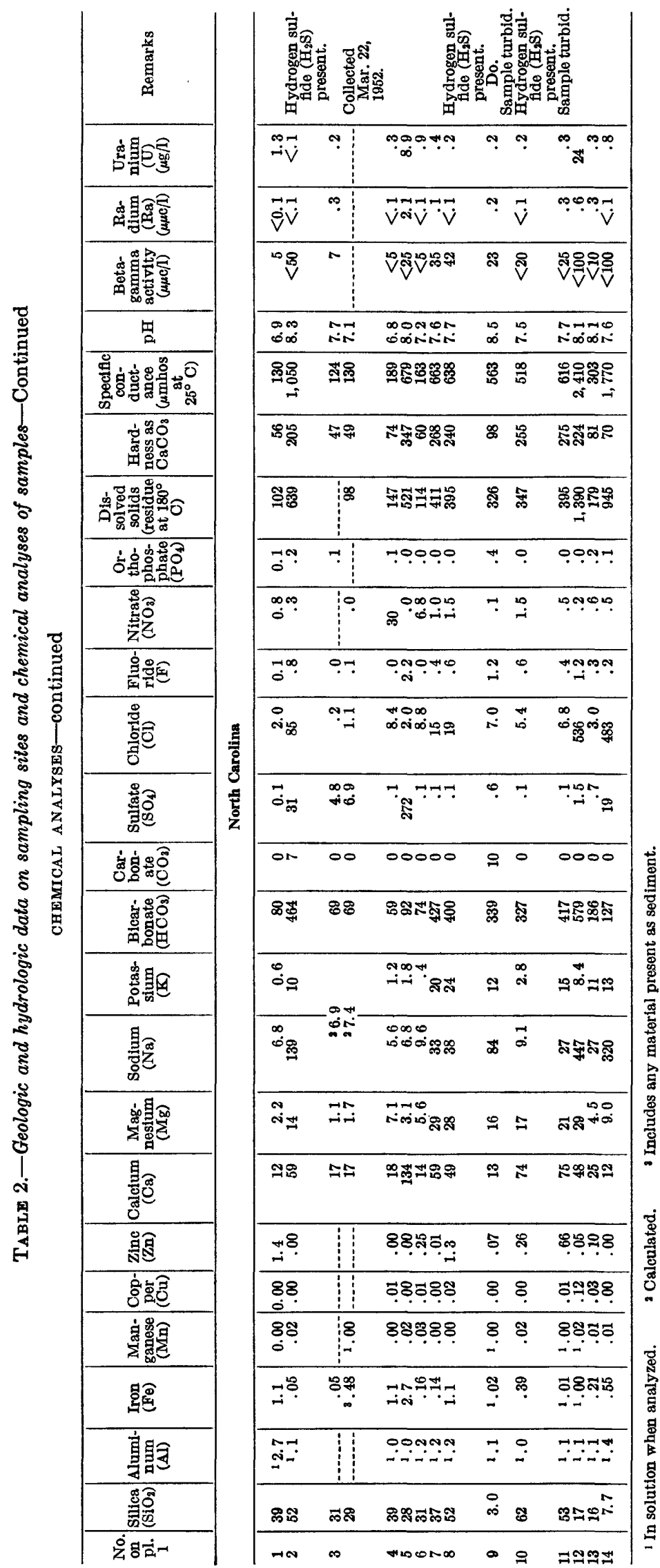




\begin{tabular}{|c|c|c|c|c|c|c|c|c|c|c|c|c|}
\hline & & 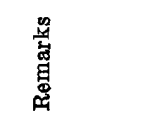 & & & 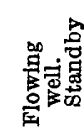 & & 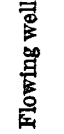 & & & & & \\
\hline & & 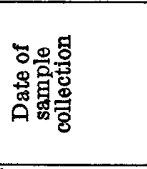 & & $\begin{array}{l}\text { 苐 } \\
\text { s. } \\
\text { s. } \\
\stackrel{0}{0} \\
0\end{array}$ & 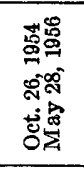 & 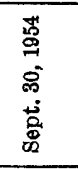 & 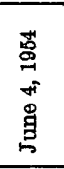 & 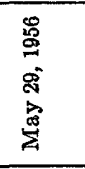 & 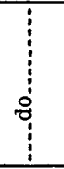 & 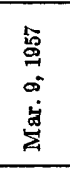 & 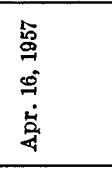 & 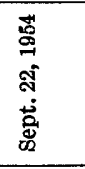 \\
\hline & & 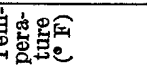 & & $\$$ & $\$$ & ร & $\ddot{0}$ & $q$ & F & $F$ & 요 & 9 \\
\hline & & 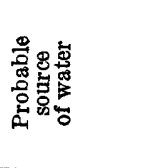 & & 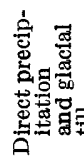 & 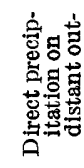 & 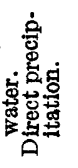 & 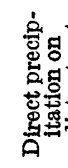 & 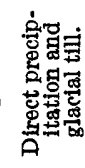 & & 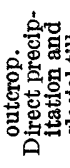 & 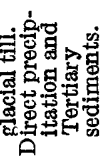 & 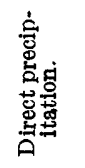 \\
\hline 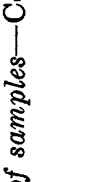 & 节 & 量 & & 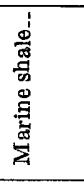 & 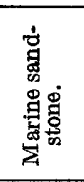 & 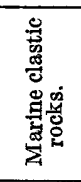 & 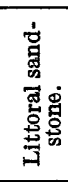 & 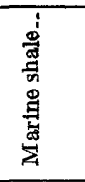 & 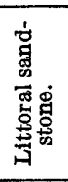 & 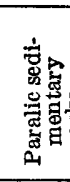 & 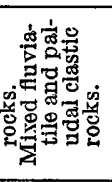 & $\frac{8}{7}$ \\
\hline & $\begin{array}{l}0 \\
0 \\
\text { 晃 }\end{array}$ & 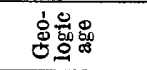 & & 4 & 0 & $\stackrel{8}{8}$ & $\approx$ & 4 & $\forall$ & $\stackrel{\infty}{*}_{1}$ & $M$ & 4 \\
\hline 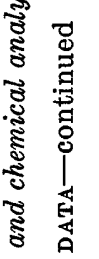 & 离 & 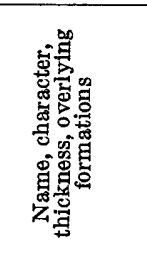 & & 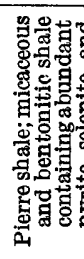 & 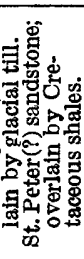 & 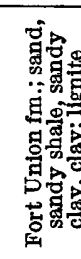 & $\begin{array}{l}\sigma_{0} \\
\omega^{2}\end{array}$ & 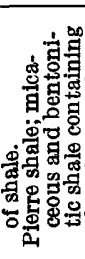 & 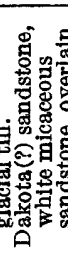 & 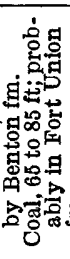 & 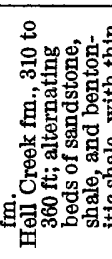 & 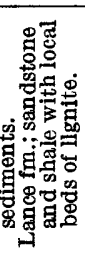 \\
\hline $\begin{array}{l}0 \\
0 \\
0 \\
0 \\
0 \\
0 \\
0\end{array}$ & & 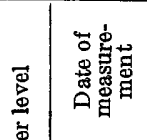 & 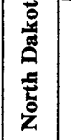 & 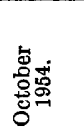 & & 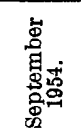 & & 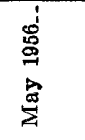 & 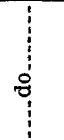 & 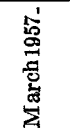 & 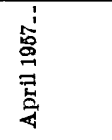 & 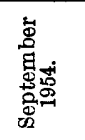 \\
\hline 至 & 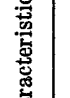 & 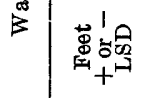 & & i & & $\stackrel{\infty}{1}$ & & i & $\stackrel{0}{+}$ & I & $\frac{8}{1}$ & $\frac{8}{1}$ \\
\hline $\begin{array}{l}3 \\
0 \\
0 \\
0 \\
0 \\
0 \\
0\end{array}$ & $\begin{array}{l}\text { है } \\
\vec{\Xi} \\
\text { है }\end{array}$ & 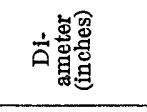 & & 윰 & + & $\cong$ & 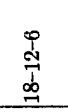 & 0 & $\infty$ & $\infty$ & 0 & $\stackrel{\infty}{a}$ \\
\hline 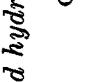 & & 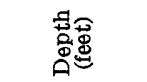 & & 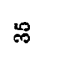 & 喿 & $\stackrel{\infty}{\oplus}$ & 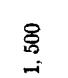 & $\stackrel{\infty}{\Xi}$ & 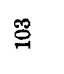 & $\infty$ & \&్ల & 8 \\
\hline & & 密言 & & 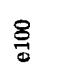 & \% & 웅 & 8 & 0 & 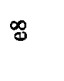 & 윤 & \& & ఖ్రి \\
\hline & & 兽 & & $\Sigma$ & $z$ & A & $\bar{z}$ & A & $\infty$ & $\Sigma$ & $\Sigma$ & $\begin{array}{l}\infty \\
\hat{A}\end{array}$ \\
\hline & & 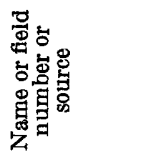 & & 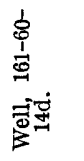 & 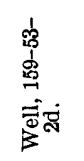 & 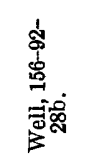 & 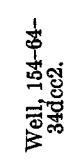 & 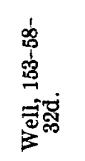 & 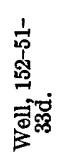 & 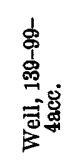 & 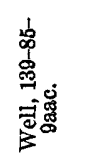 & 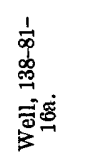 \\
\hline & & 总 & & 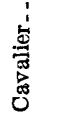 & 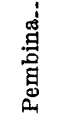 & 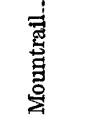 & 密 & 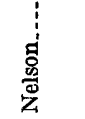 & 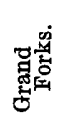 & 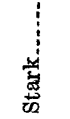 & $\begin{array}{c}\vdots \\
\vdots \\
\frac{0}{00} \\
\frac{0}{2}\end{array}$ & $\stackrel{\square}{\square}$ \\
\hline & 急 & 害 & & 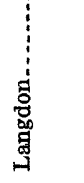 & 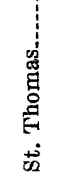 & 离 & 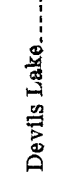 & 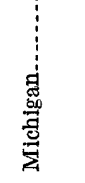 & 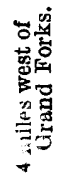 & 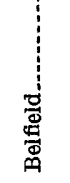 & 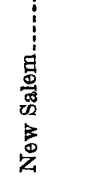 & 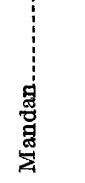 \\
\hline & & 영명- & & -1 & $\sigma$ & $\infty$ & + & 10 & ${ }^{\circ}$ & $N$ & $\infty$ & \\
\hline
\end{tabular}


GEOLOGIC, HYDRoLogIC, AND CHEMICAL DATA

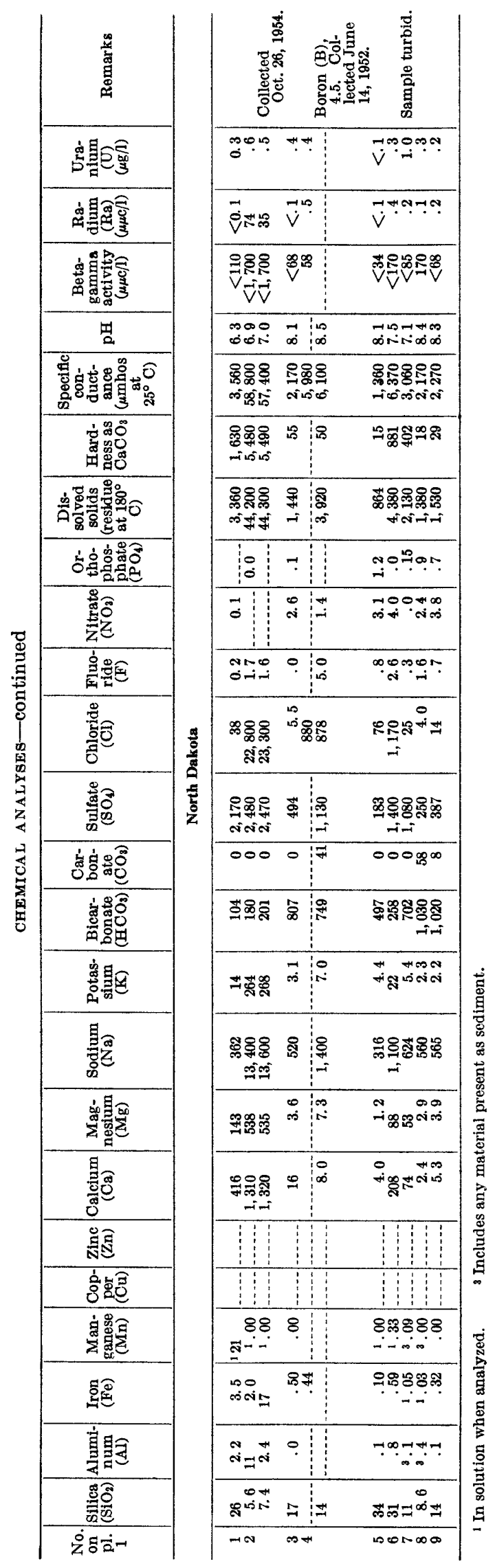




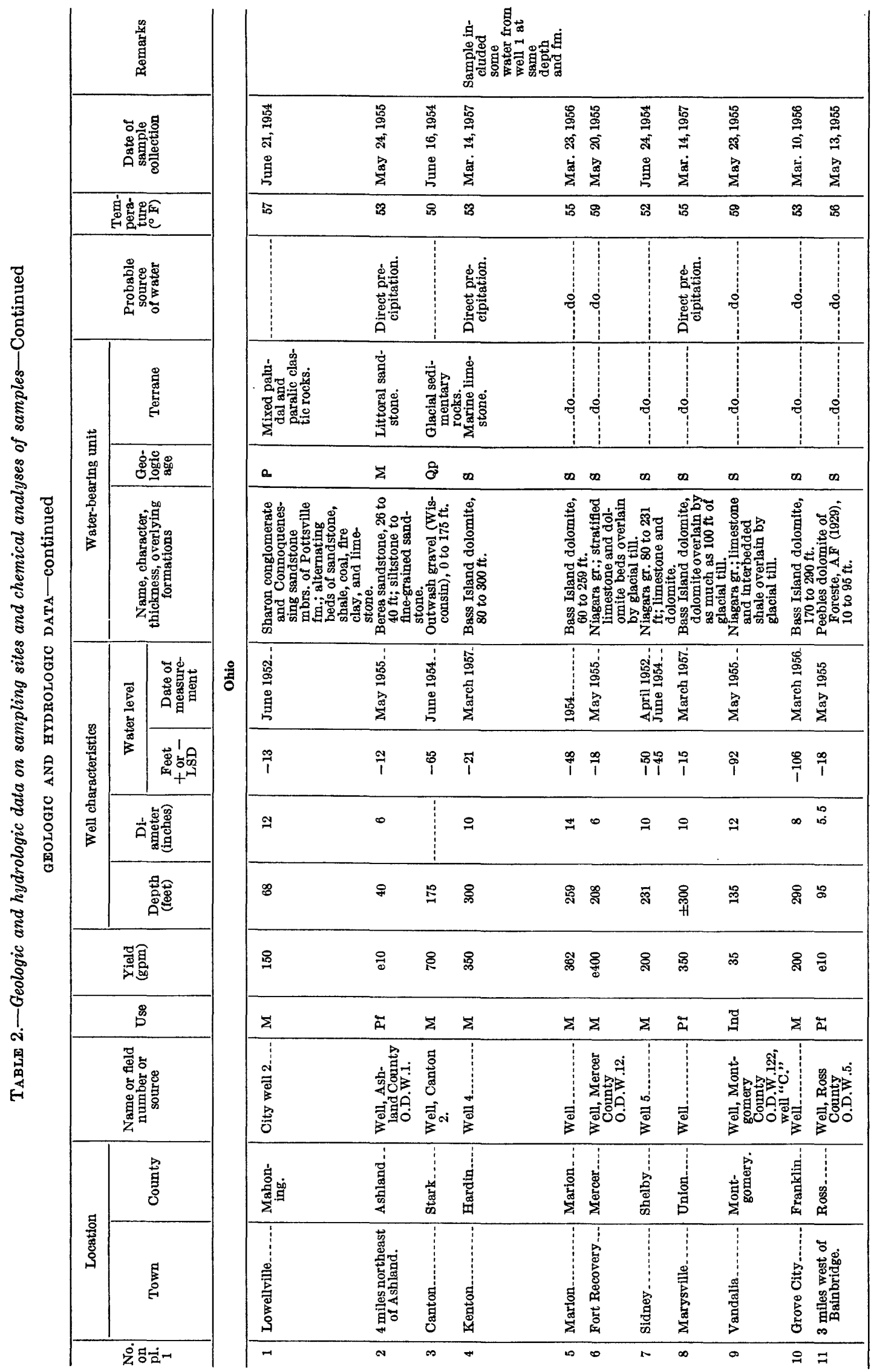




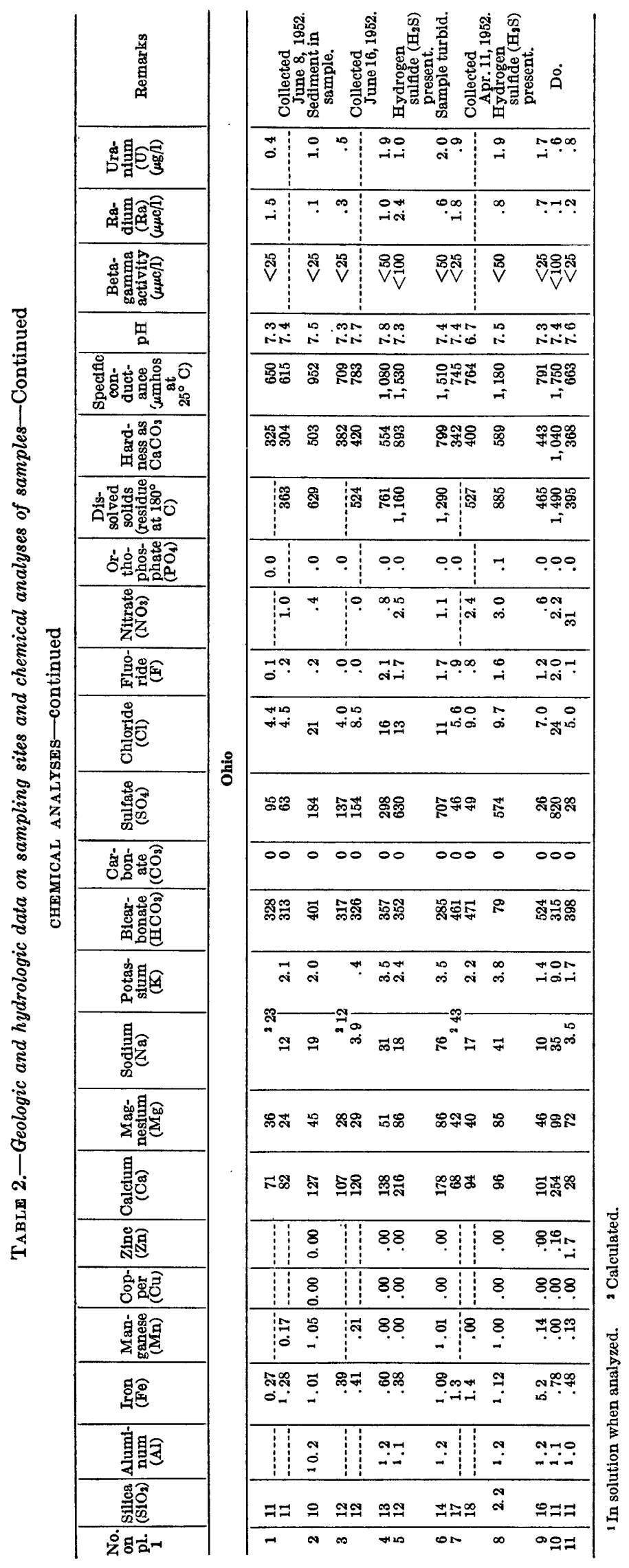




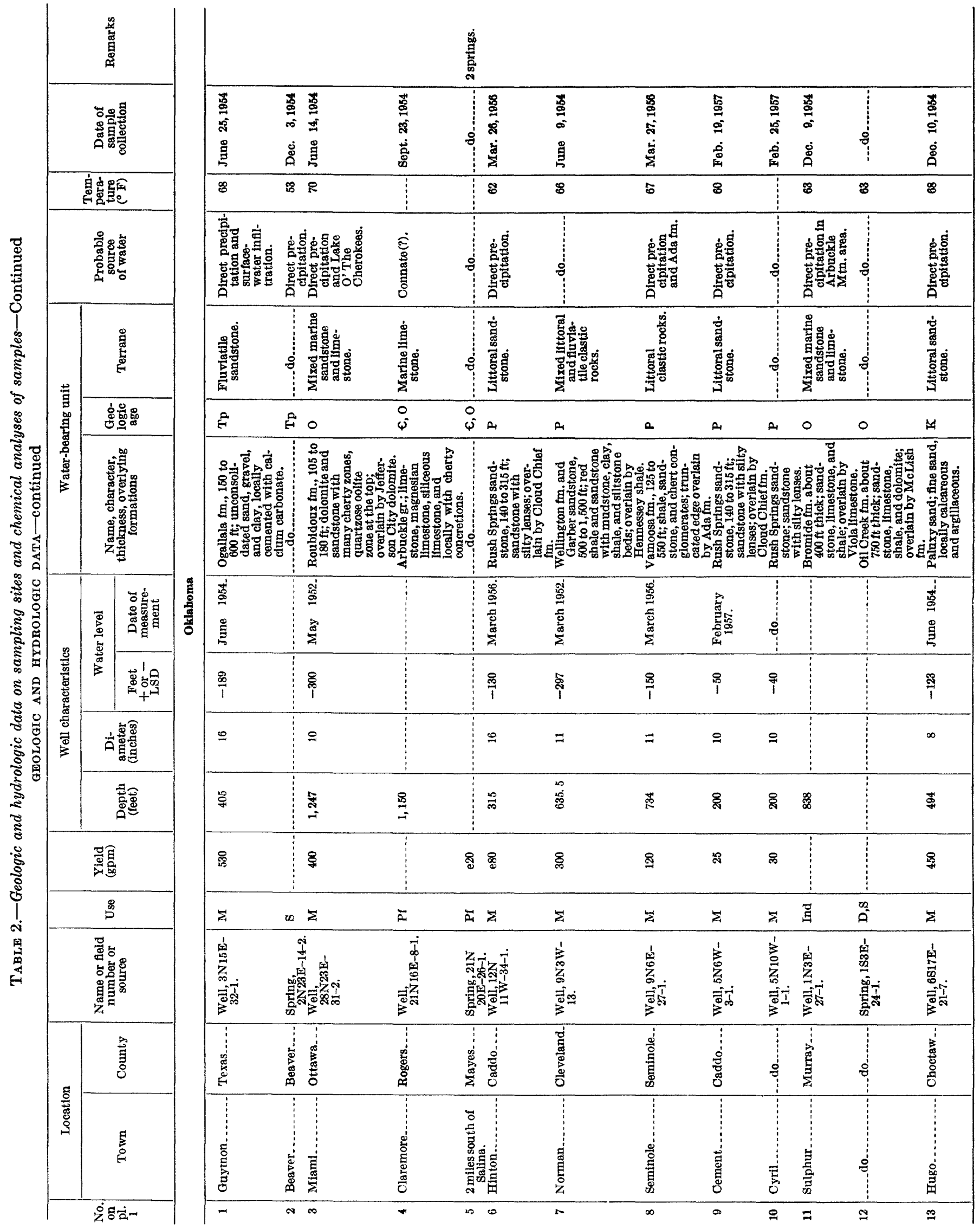


GEOLOGIC, HYDROLOGIC, AND CHEMICAL DATA

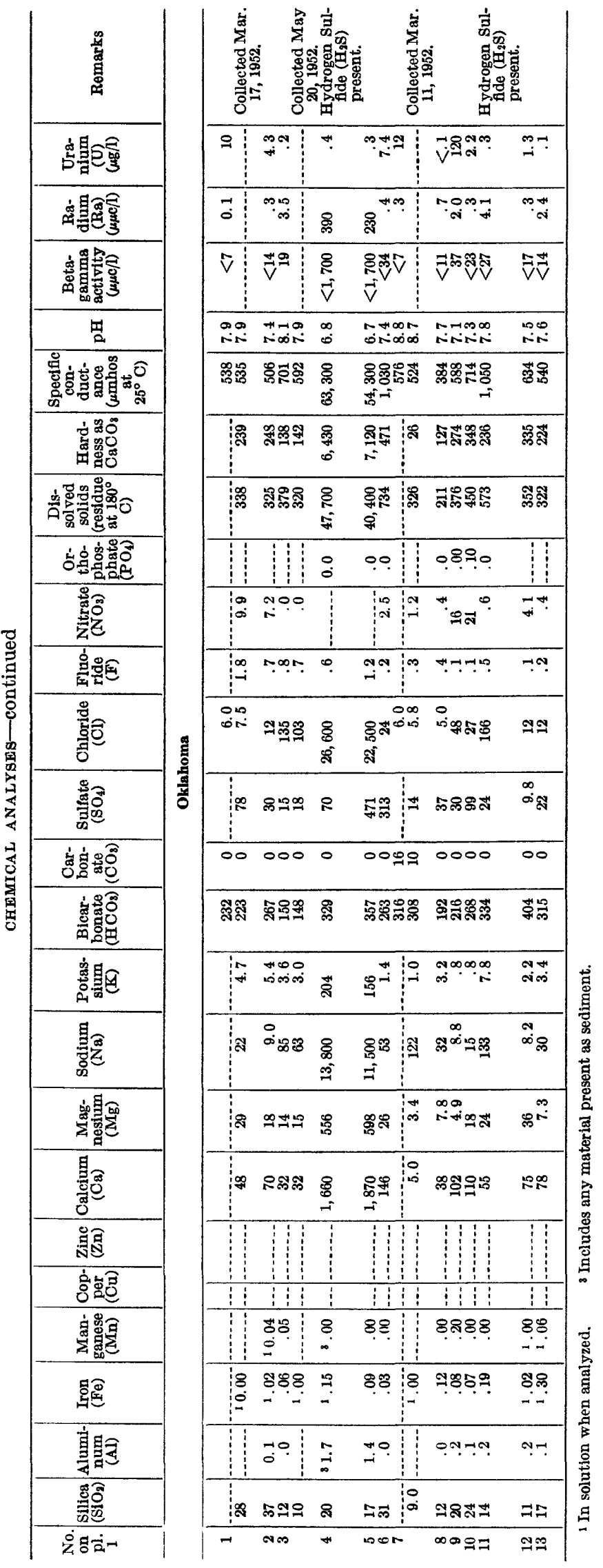




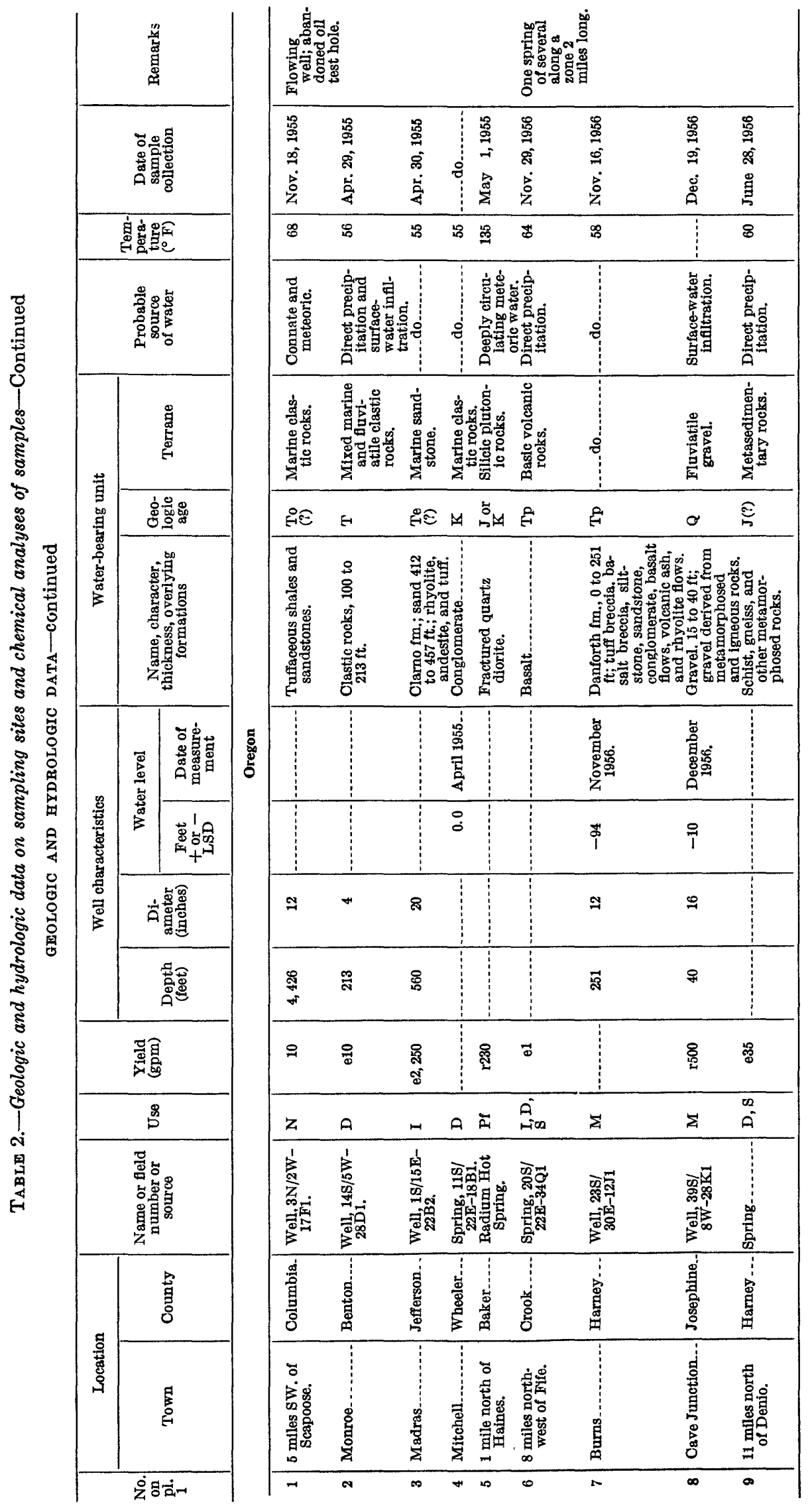


GEOLOGIC, HYDROLOGIC; AND CHEMICAL DATA

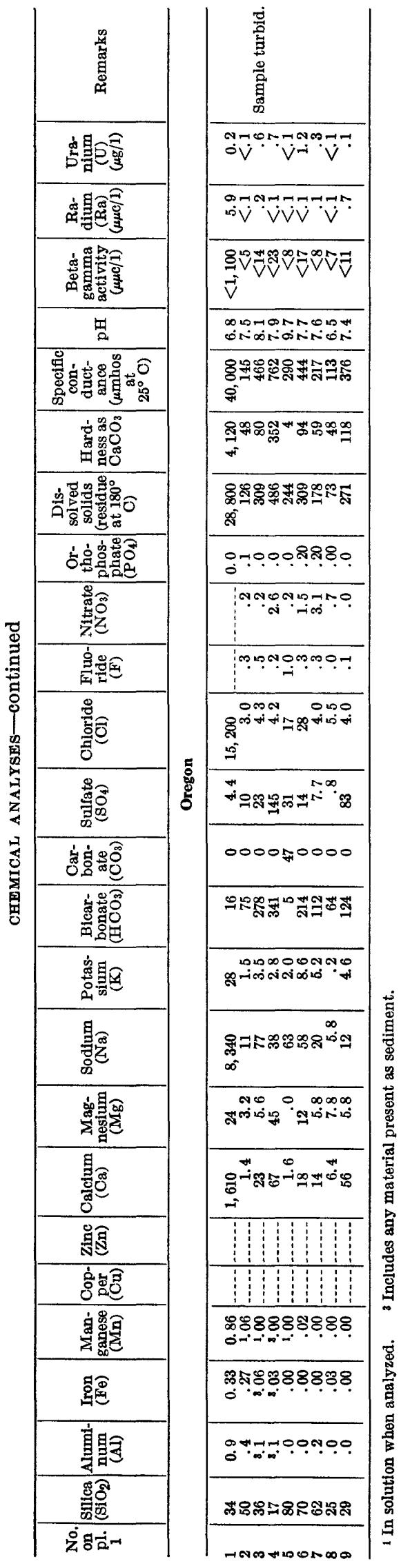




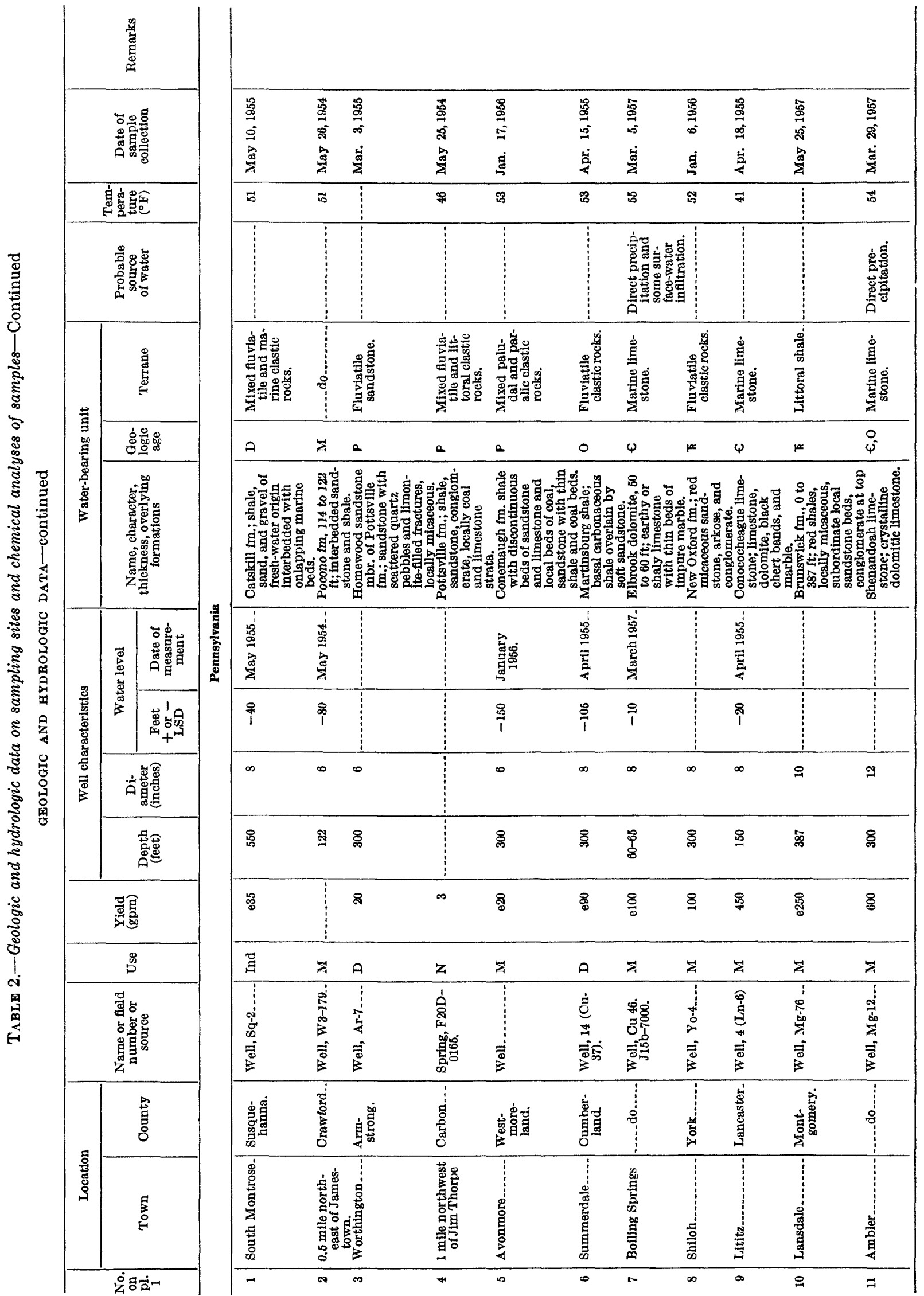


GEOLOGIC, HYDRÓLOGIĆ, AND CHEMICAL DATA

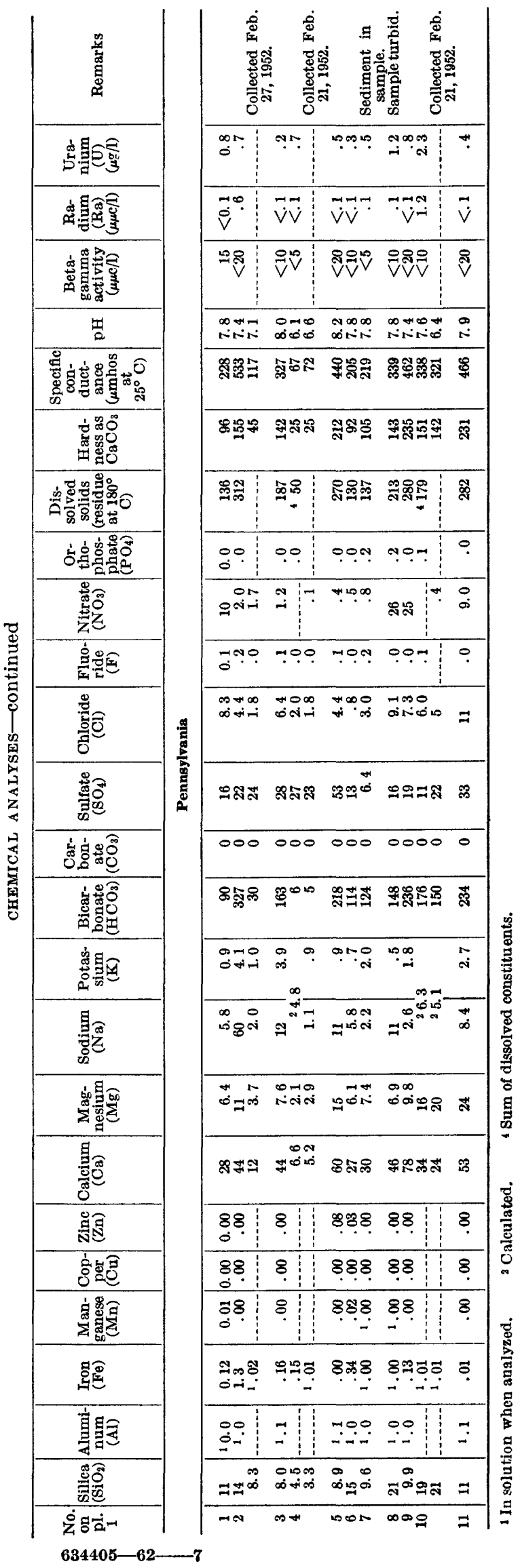


94 DATA ON URANIUM AND RADIUM IN GROUND WATER IN UNITED STATES, 1954 TO 1957

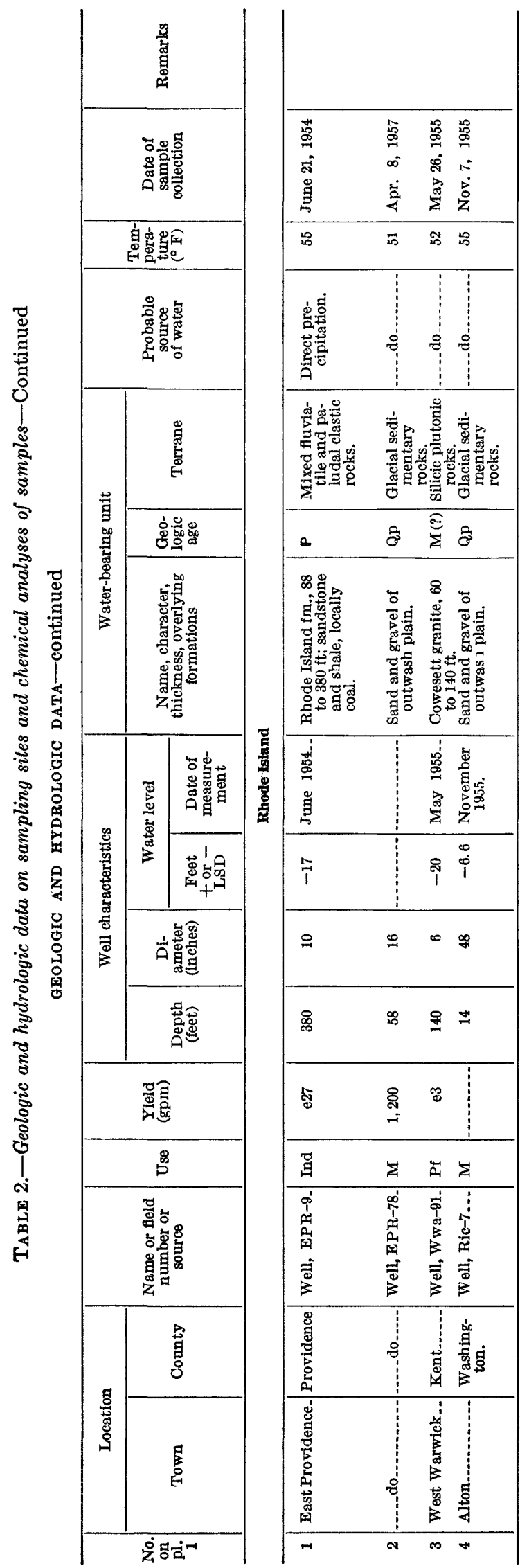


GEOLOGIC, HYDROLOGIC, AND CHEMICAL DATA

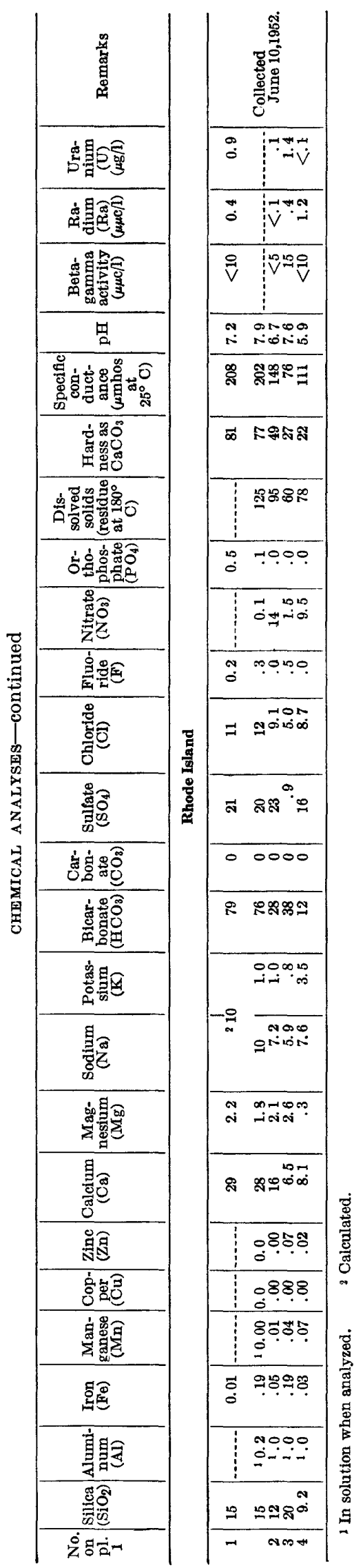




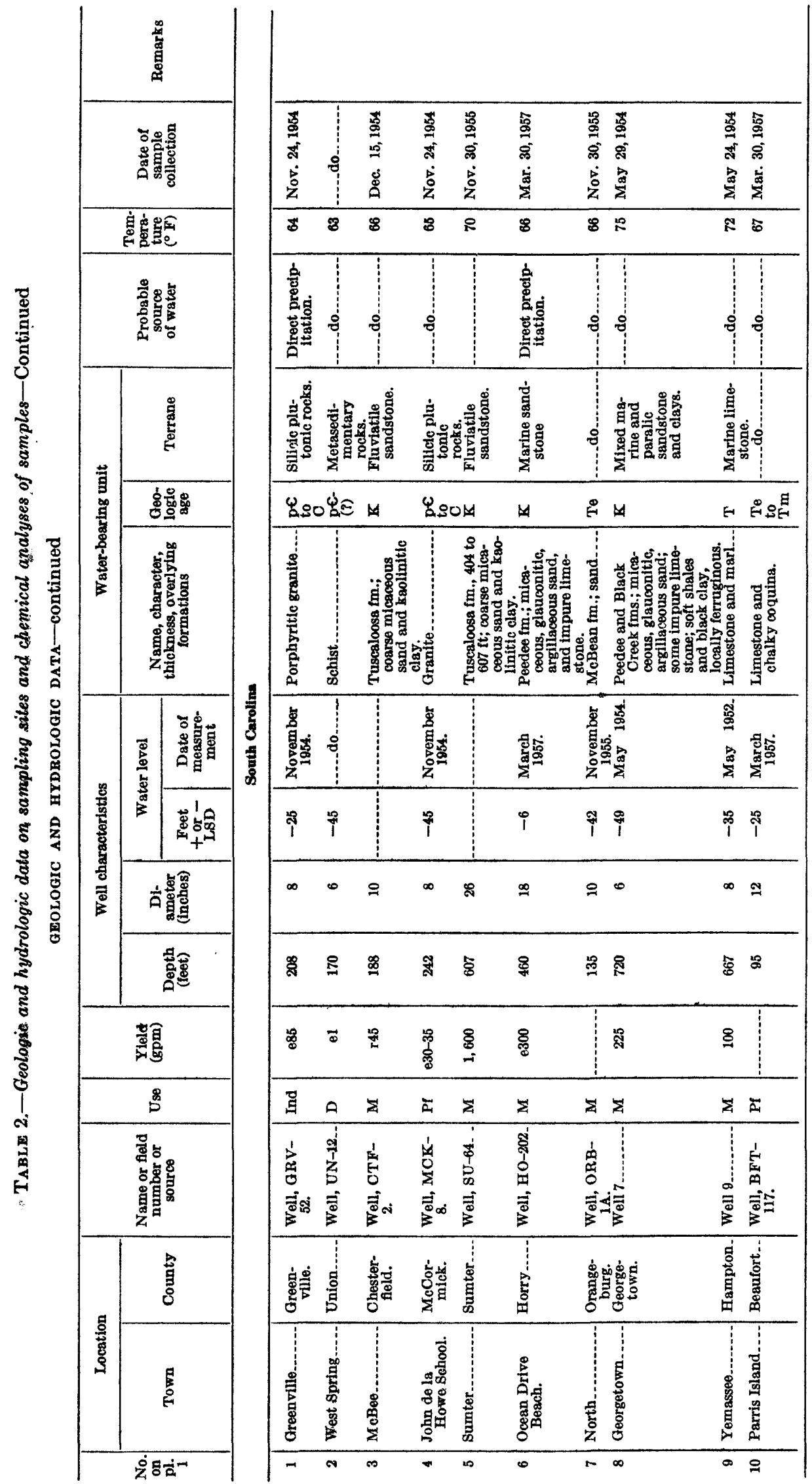




\begin{tabular}{|c|c|c|c|c|c|}
\hline 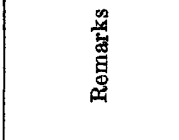 & \multirow{26}{*}{ 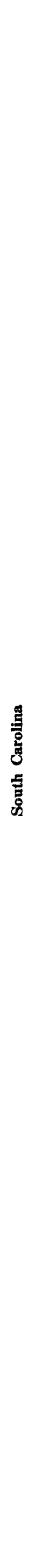 } & 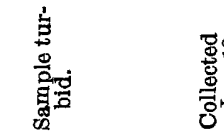 & & & 年 \\
\hline 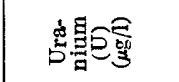 & & 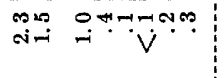 & & 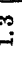 & $\vec{a}$ \\
\hline 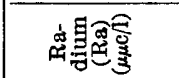 & & 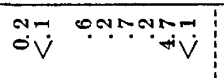 & & $\ddot{v}$ & $\overrightarrow{\vec{v}}$ \\
\hline 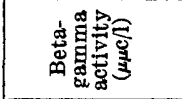 & & $92+\infty)$ & & $\vec{v}$ & $\ddot{\nabla}$ \\
\hline 思 & & 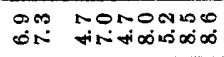 & & - & $\stackrel{\infty}{i}$ \\
\hline 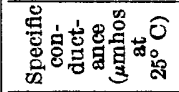 & & 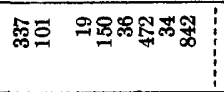 & & & $\Phi$ \\
\hline 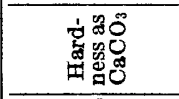 & & 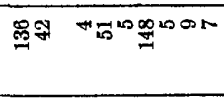 & & 5 & 혐 \\
\hline 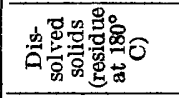 & & 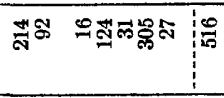 & & & $\bar{m}$ \\
\hline 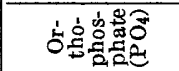 & & 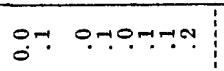 & & 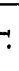 & $\stackrel{9}{9}$ \\
\hline 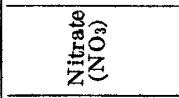 & & 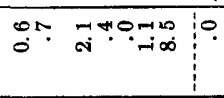 & & $\varphi$ & $\stackrel{\sim}{-}$ \\
\hline 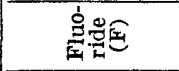 & & 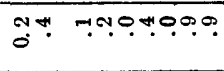 & & : & 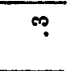 \\
\hline 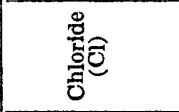 & & 象 & & +2 & $\stackrel{乛}{\sim}$ \\
\hline 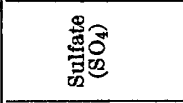 & & 0.19000000 & & 0 & \\
\hline 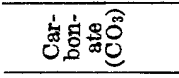 & & 0000000 저్ㅠ & & o & \\
\hline 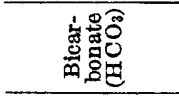 & & 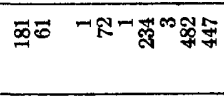 & & i & $\bar{\Xi}$ \\
\hline 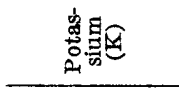 & & 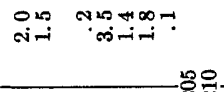 & & & $\stackrel{\infty}{\infty}$ \\
\hline 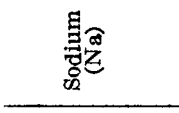 & & 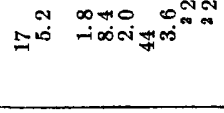 & & $R$ & $\Rightarrow$ \\
\hline 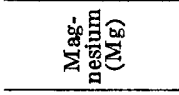 & & Y. & & & 9 \\
\hline 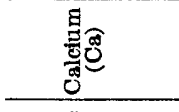 & & 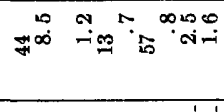 & & & \\
\hline 총 & & $8 \% 888 \%$ & & ? & 8 \\
\hline 高蛒 & & $8 \% 8888 \%$ & & 8 & 8 \\
\hline 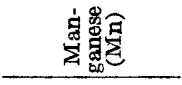 & & 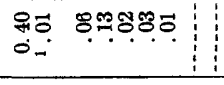 & & & 8 \\
\hline 䟿 & & 央 & & 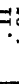 & \\
\hline 戛㲘 & & $00.0=-7=0$ & & $\Xi$ & $\Xi$ \\
\hline 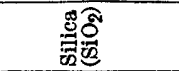 & & 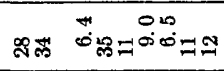 & & 8 & $\$$ \\
\hline ஜृ: $8 \dot{a}-1$ & & 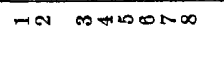 & & & 9 \\
\hline
\end{tabular}


DATA ON URANIUM AND RADIUM IN GROUND WATER IN UNITED STATES, 1954 TO 1957

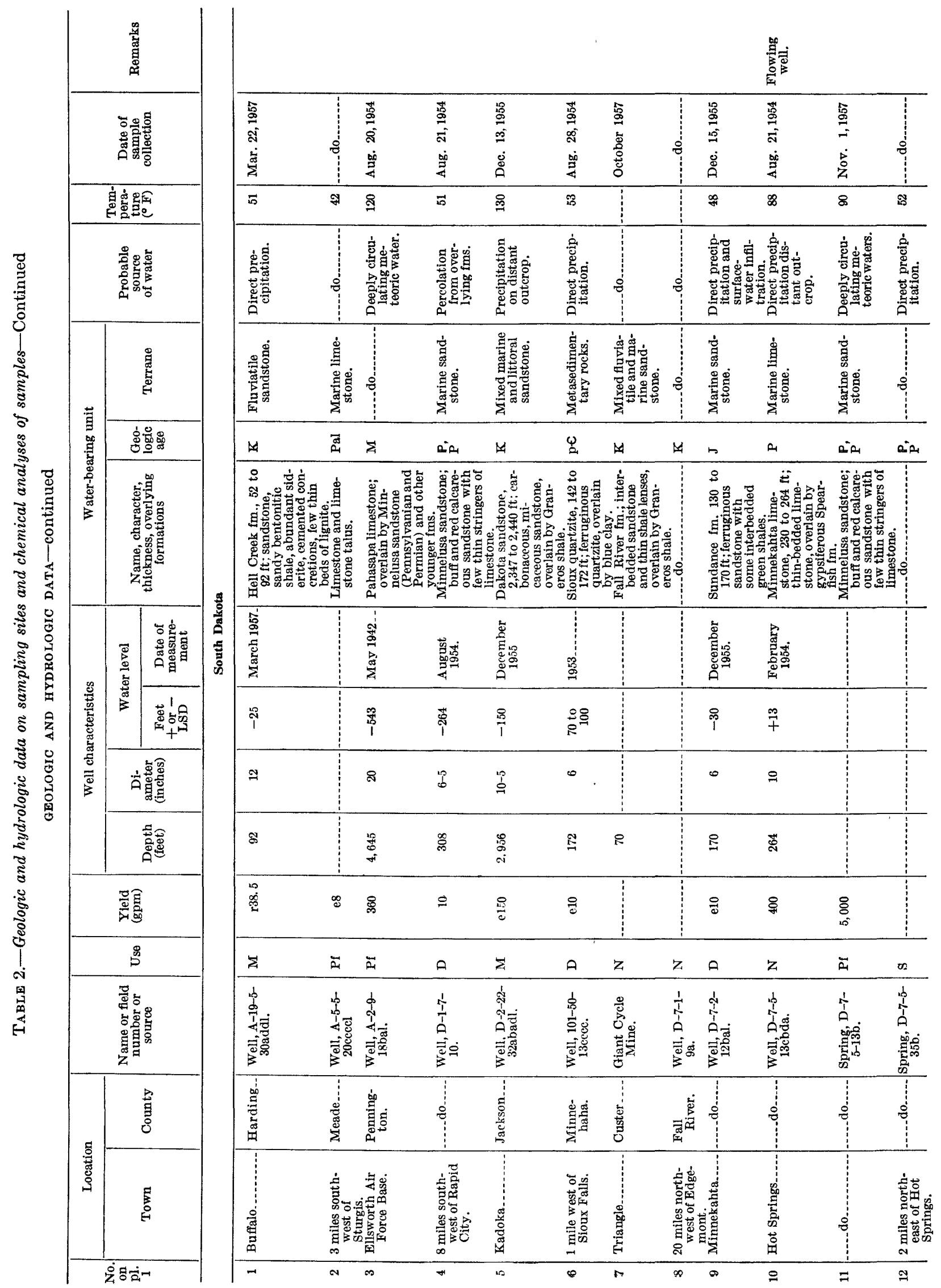


GEOLOGIC, HYDROLOGIC, AND CHEMICAL DATA

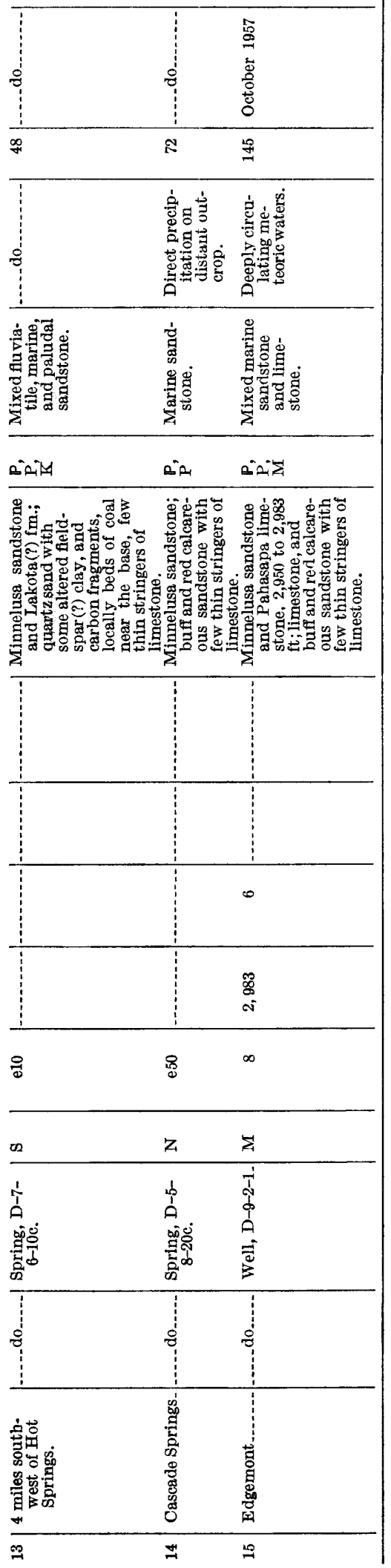

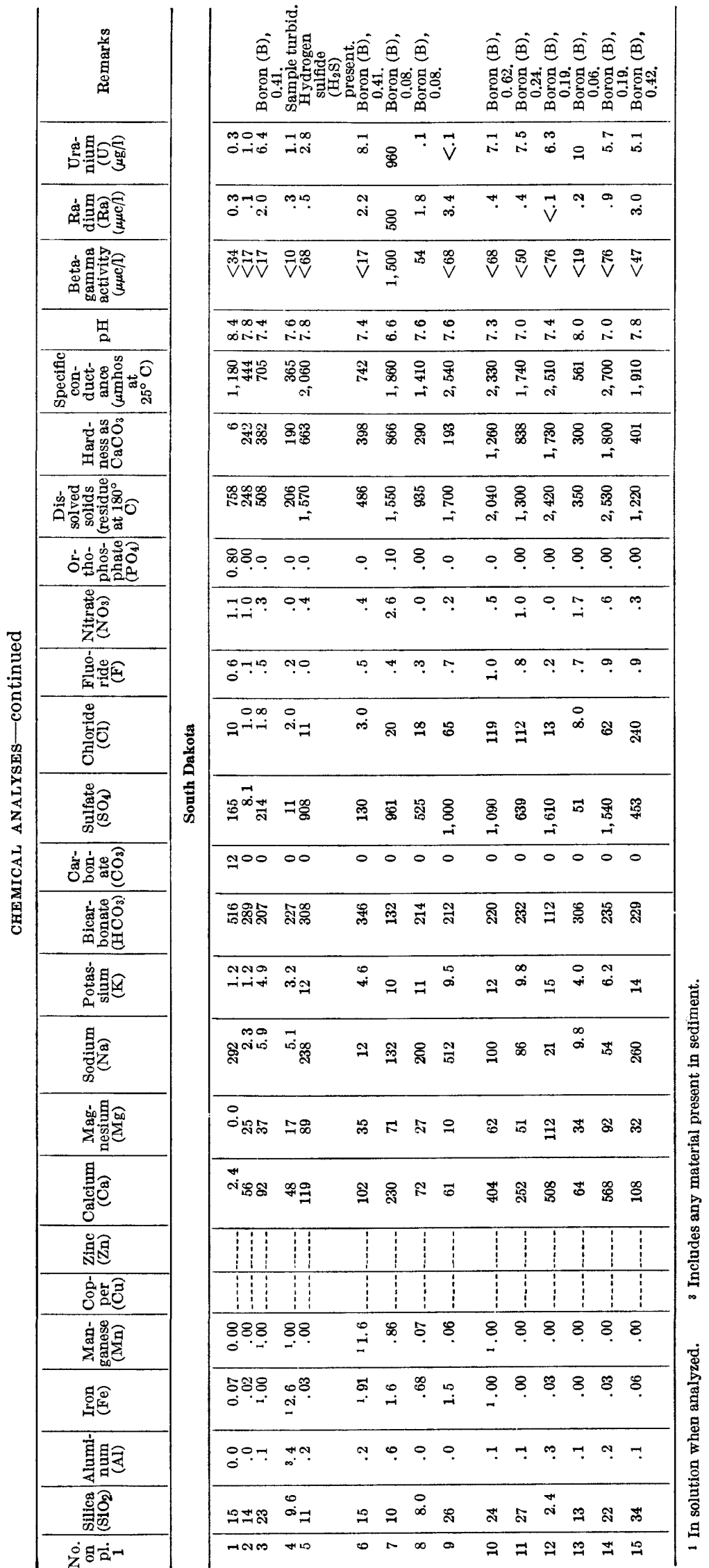




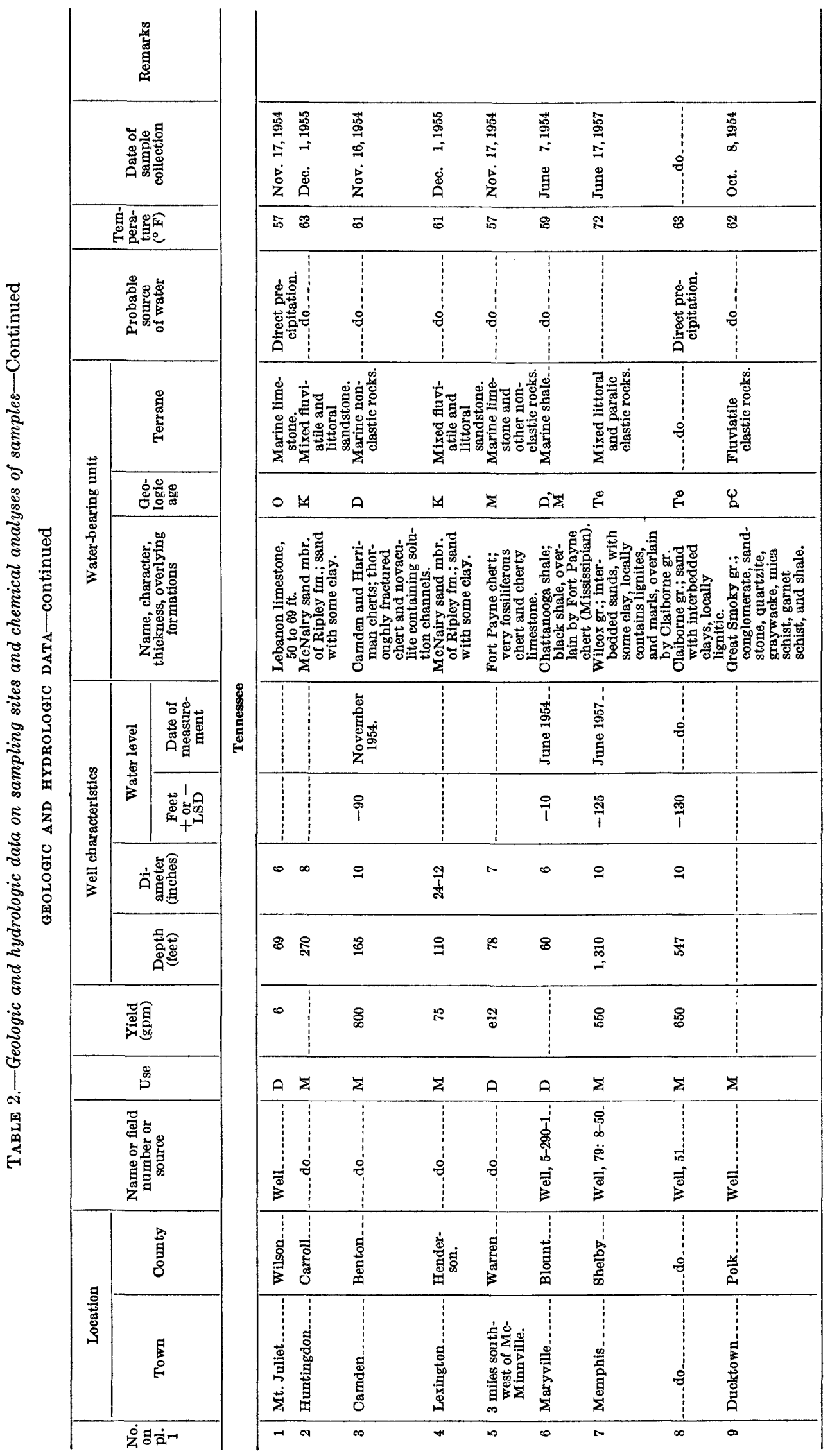




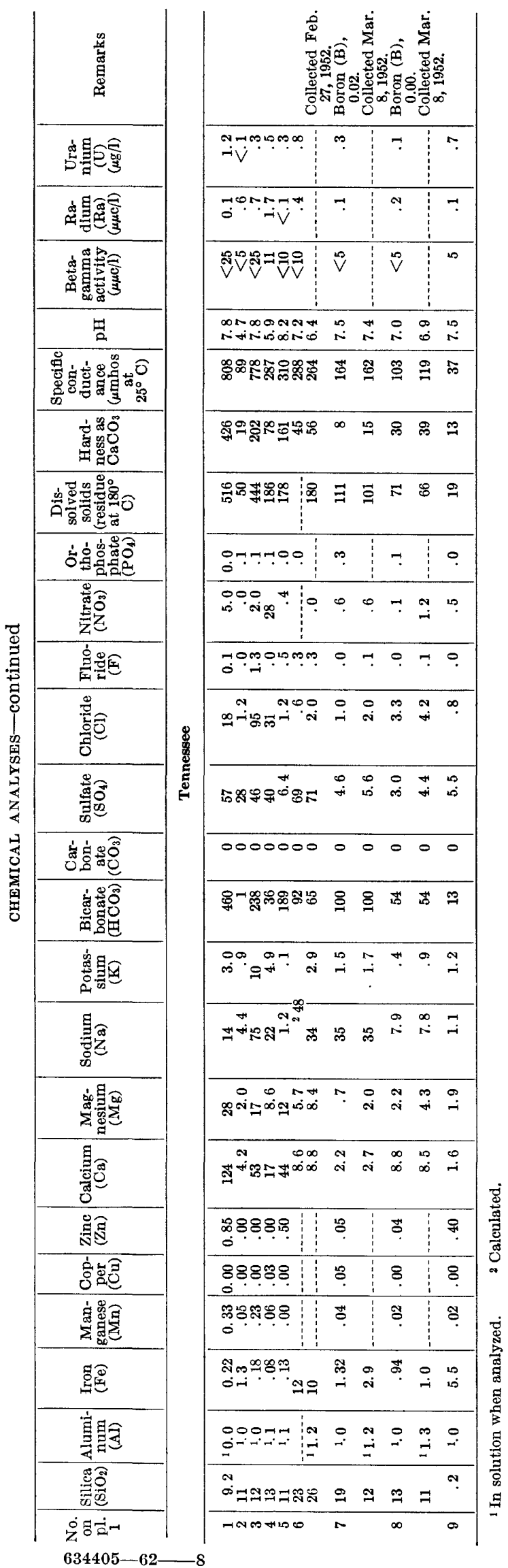




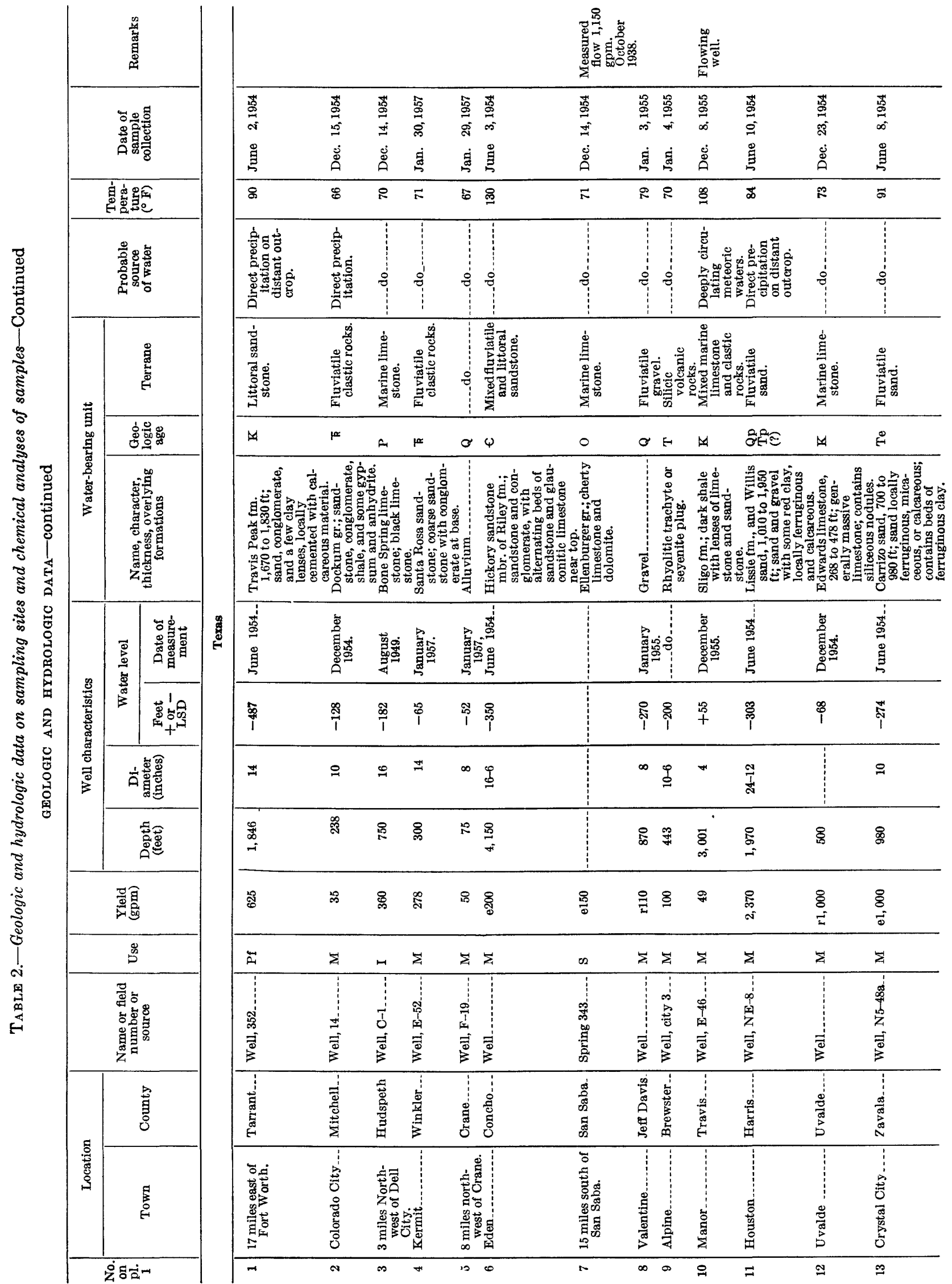


GEOLOGIC, HYDROLOGIC, AND CHEMICAL DATA
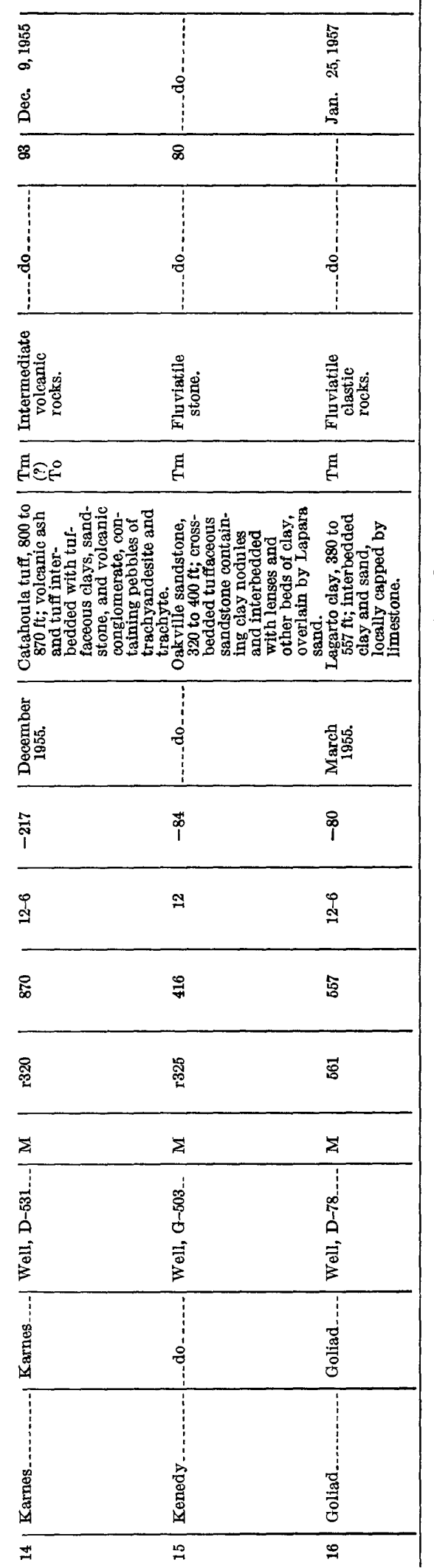

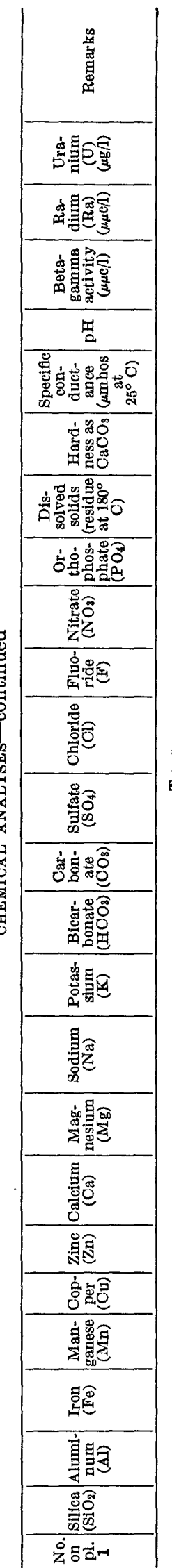




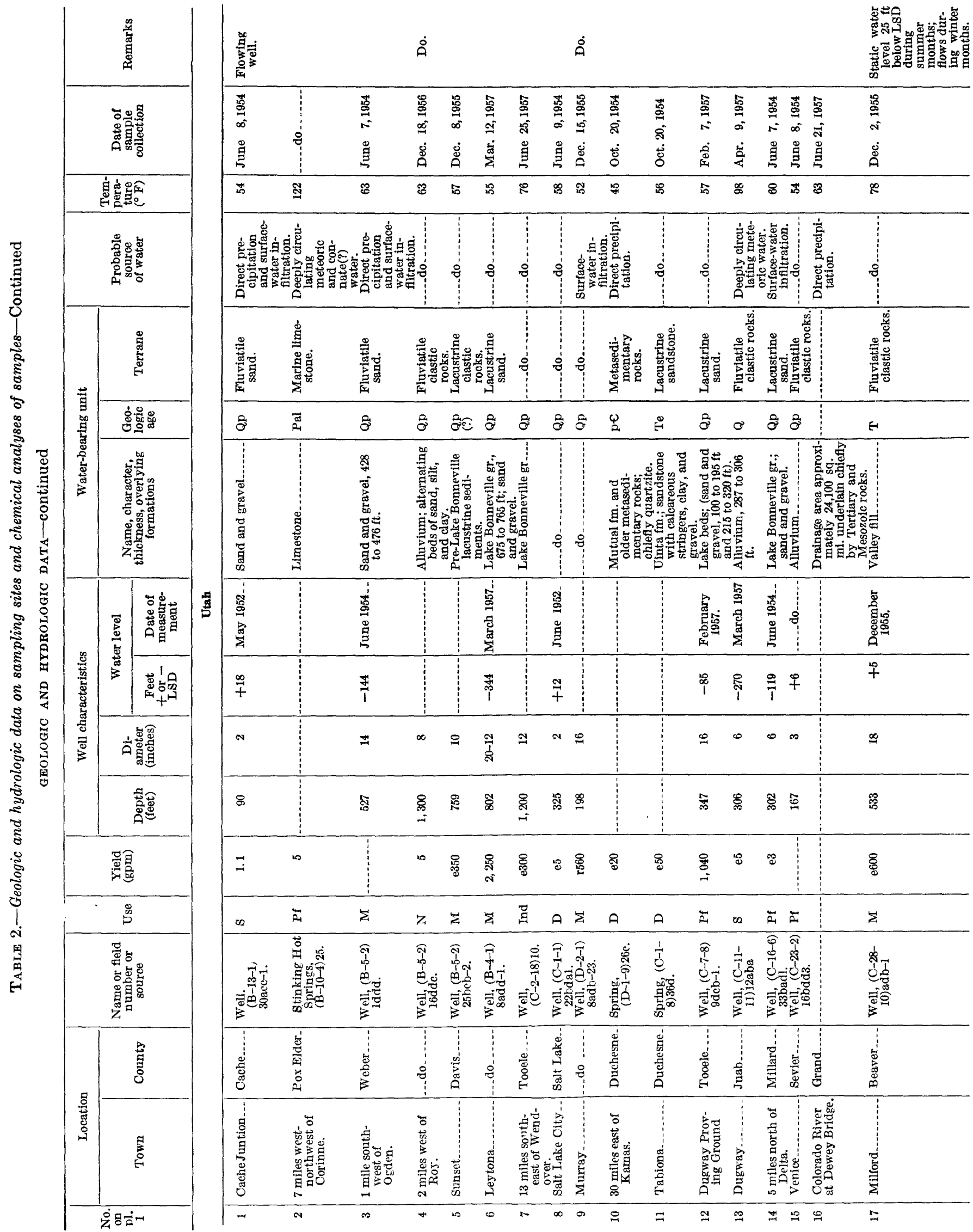


GEOLOGIC, HYDROLOGIC, AND CHEMICAL DATA

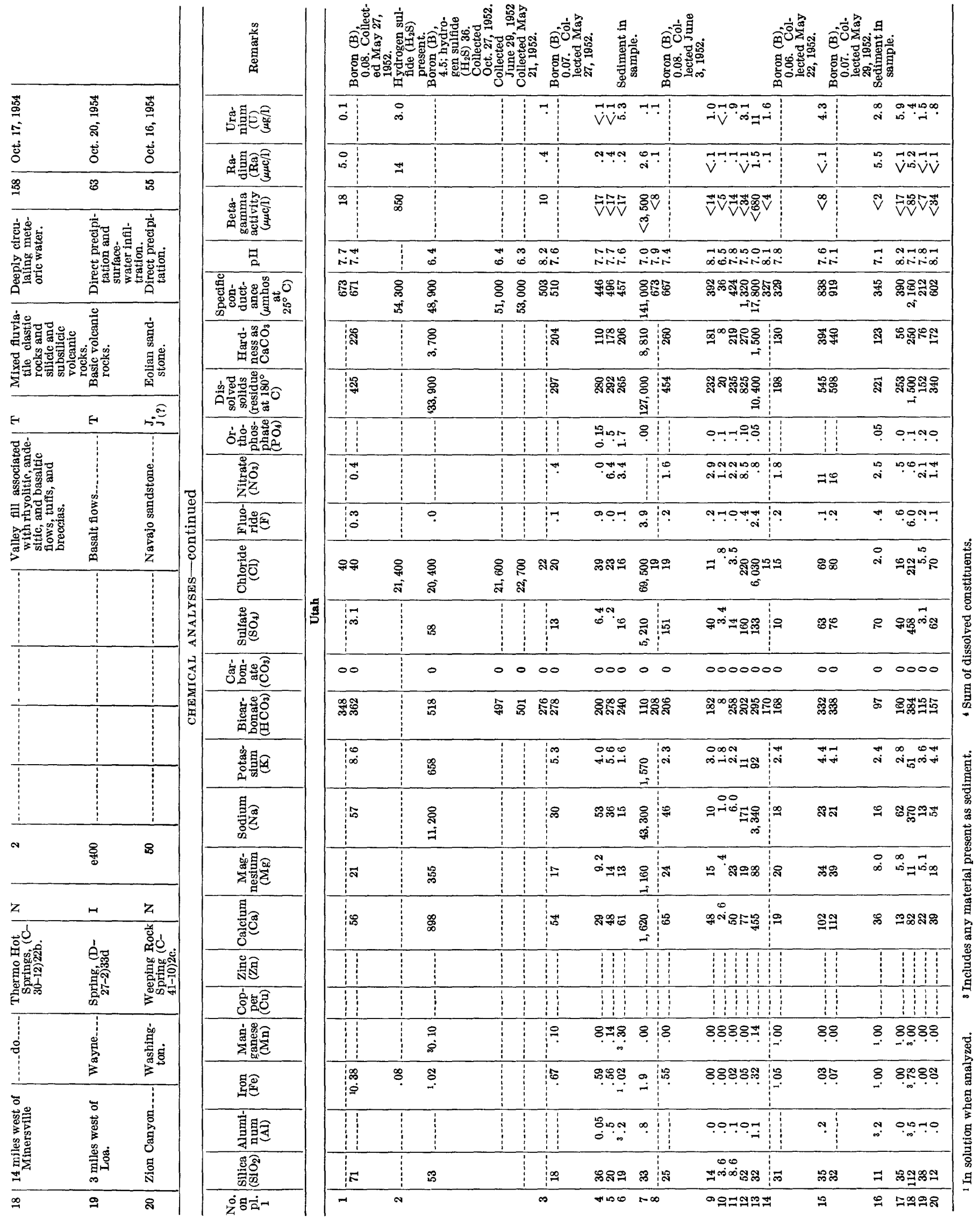




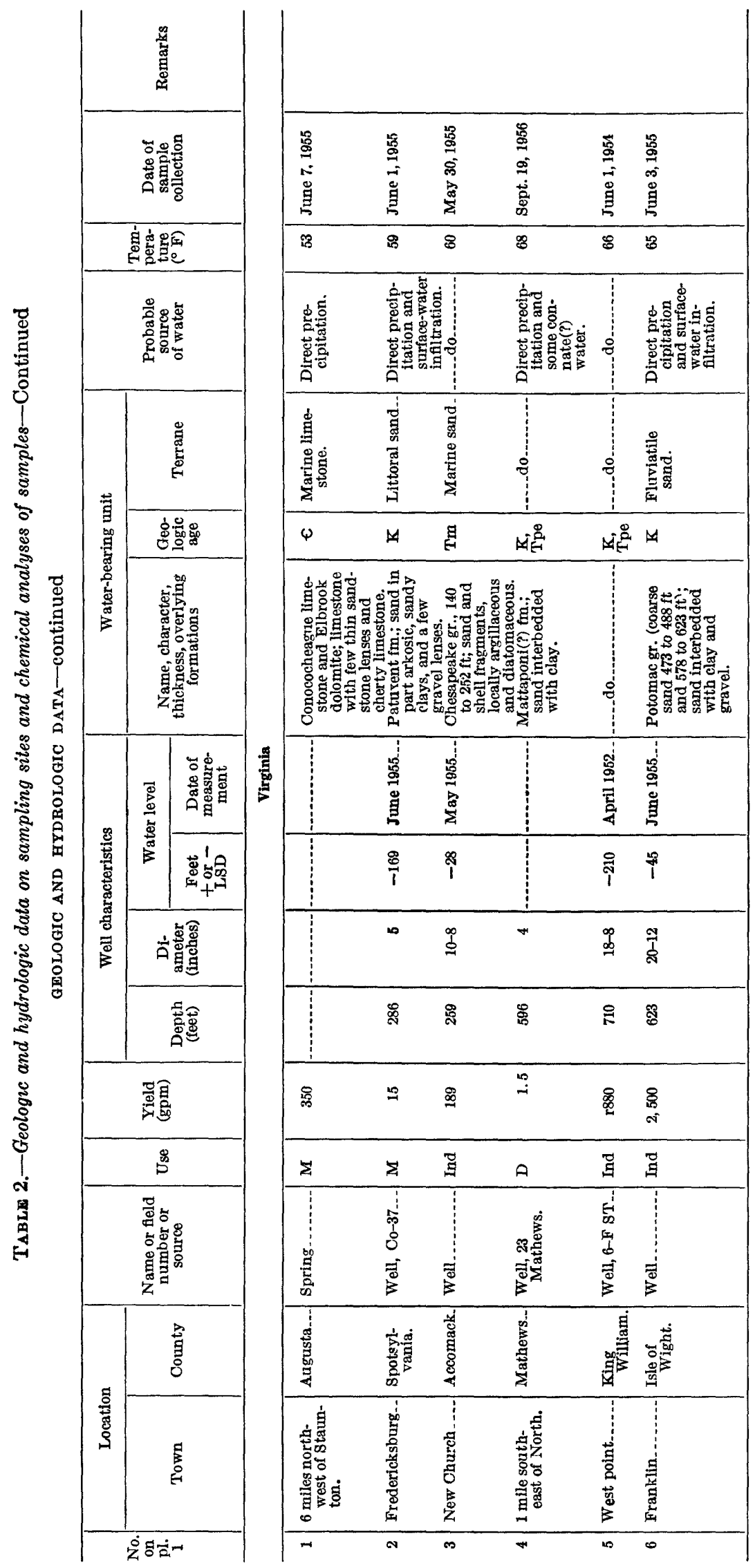




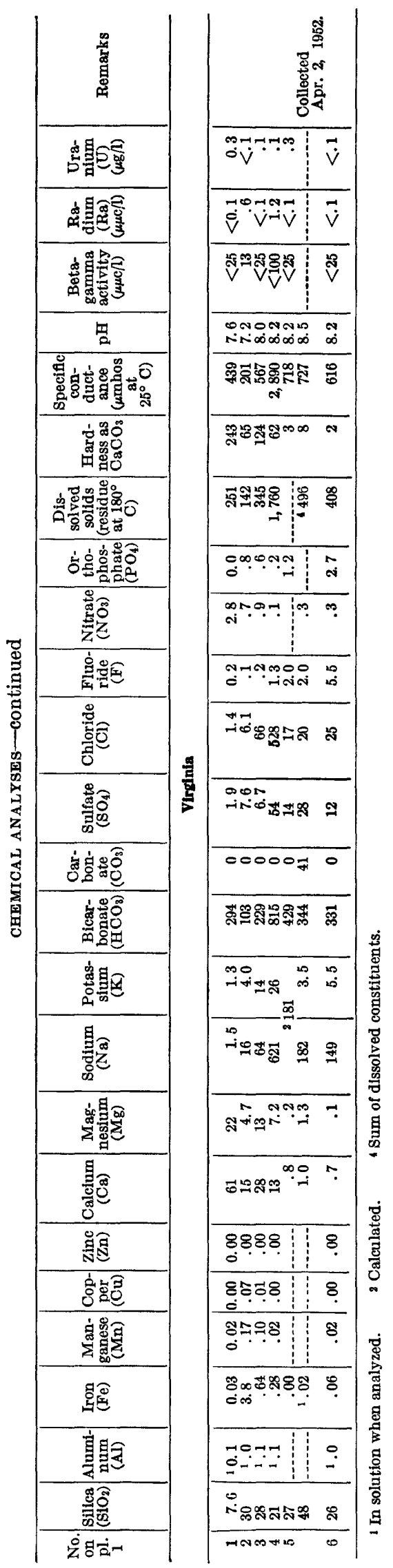




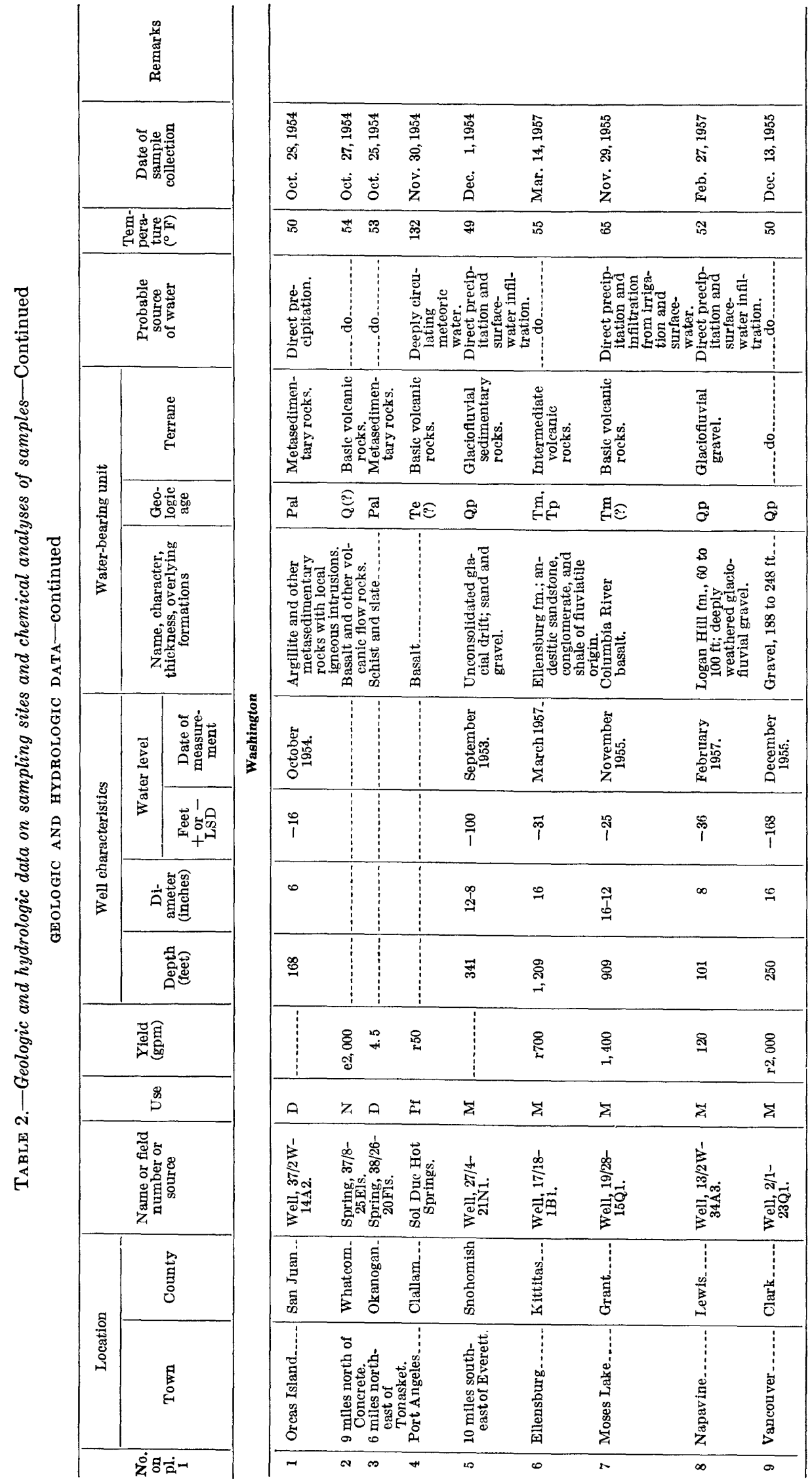




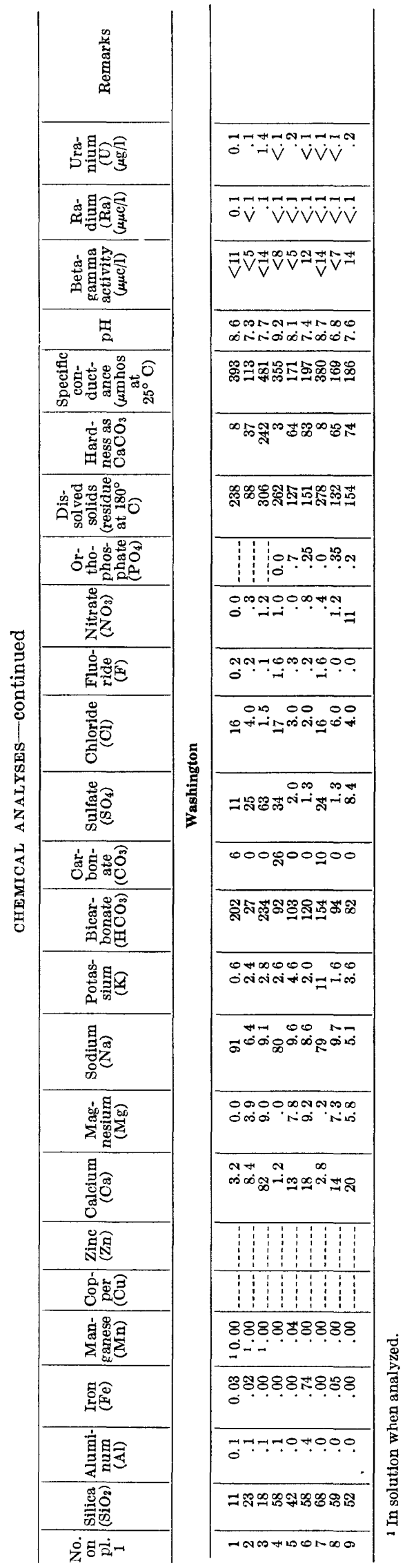




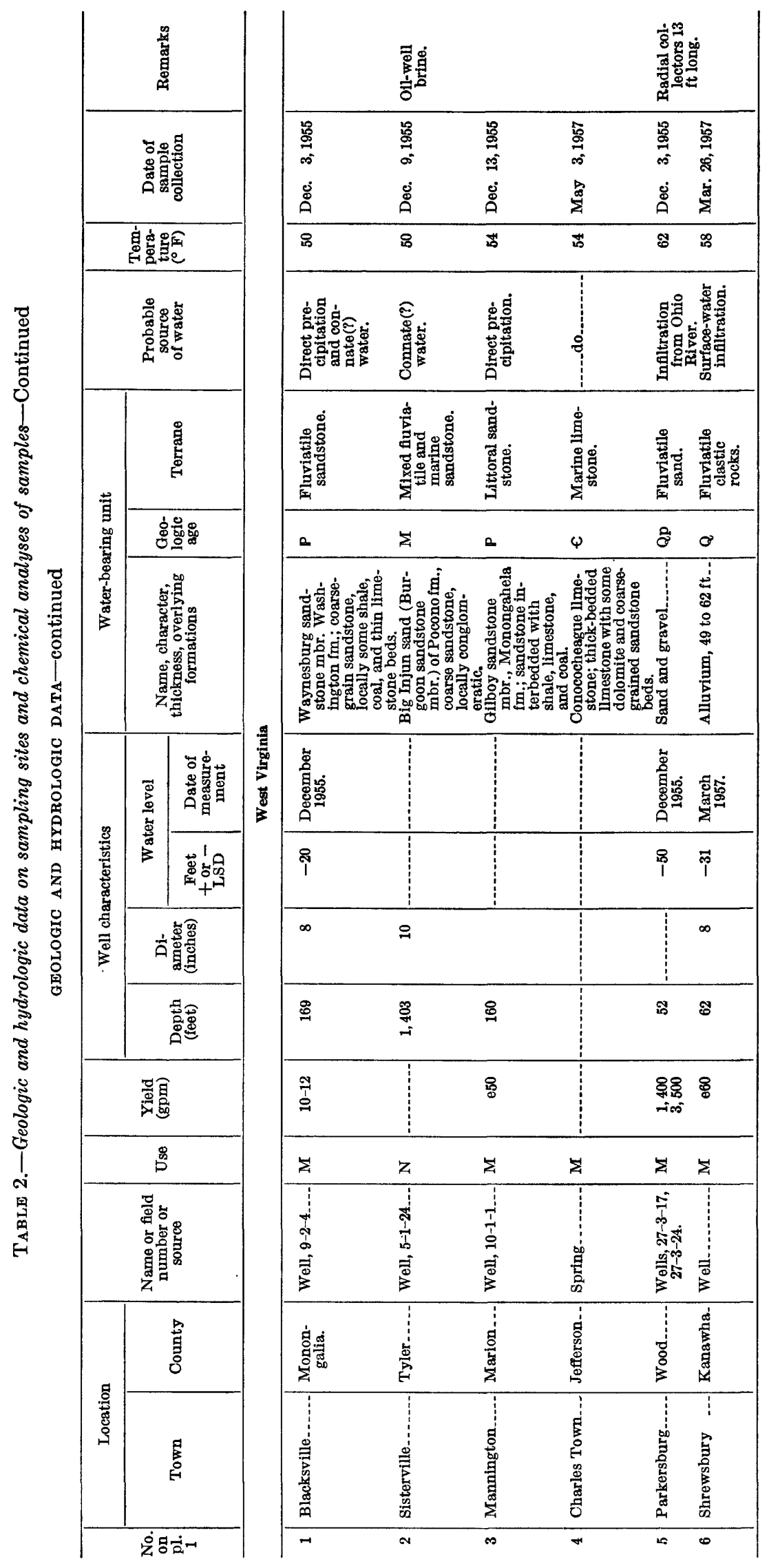




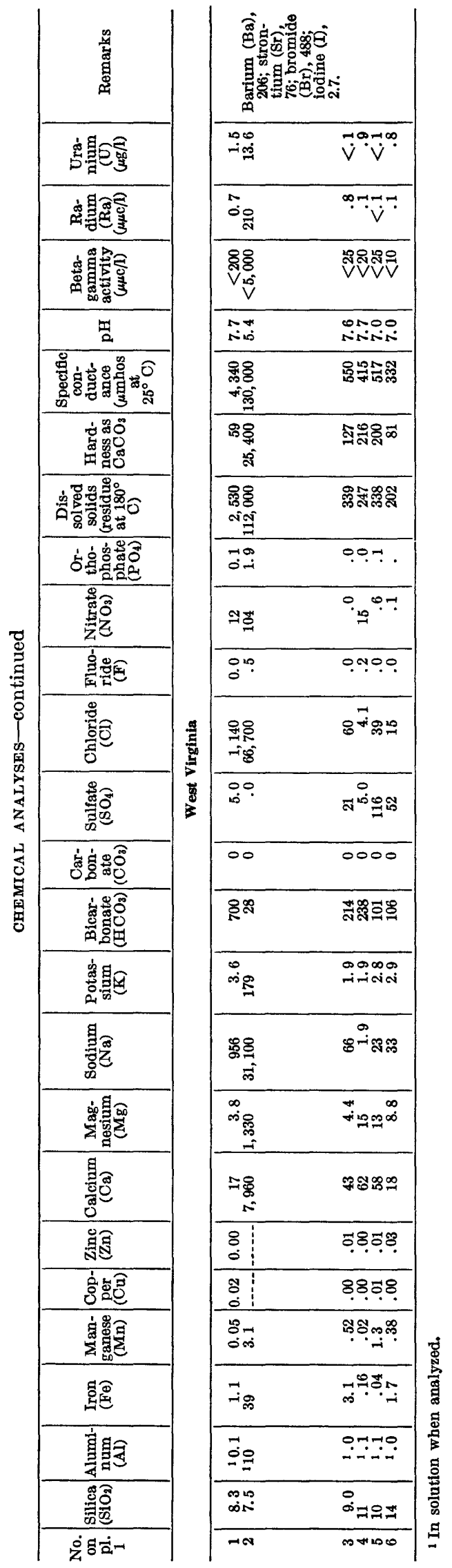




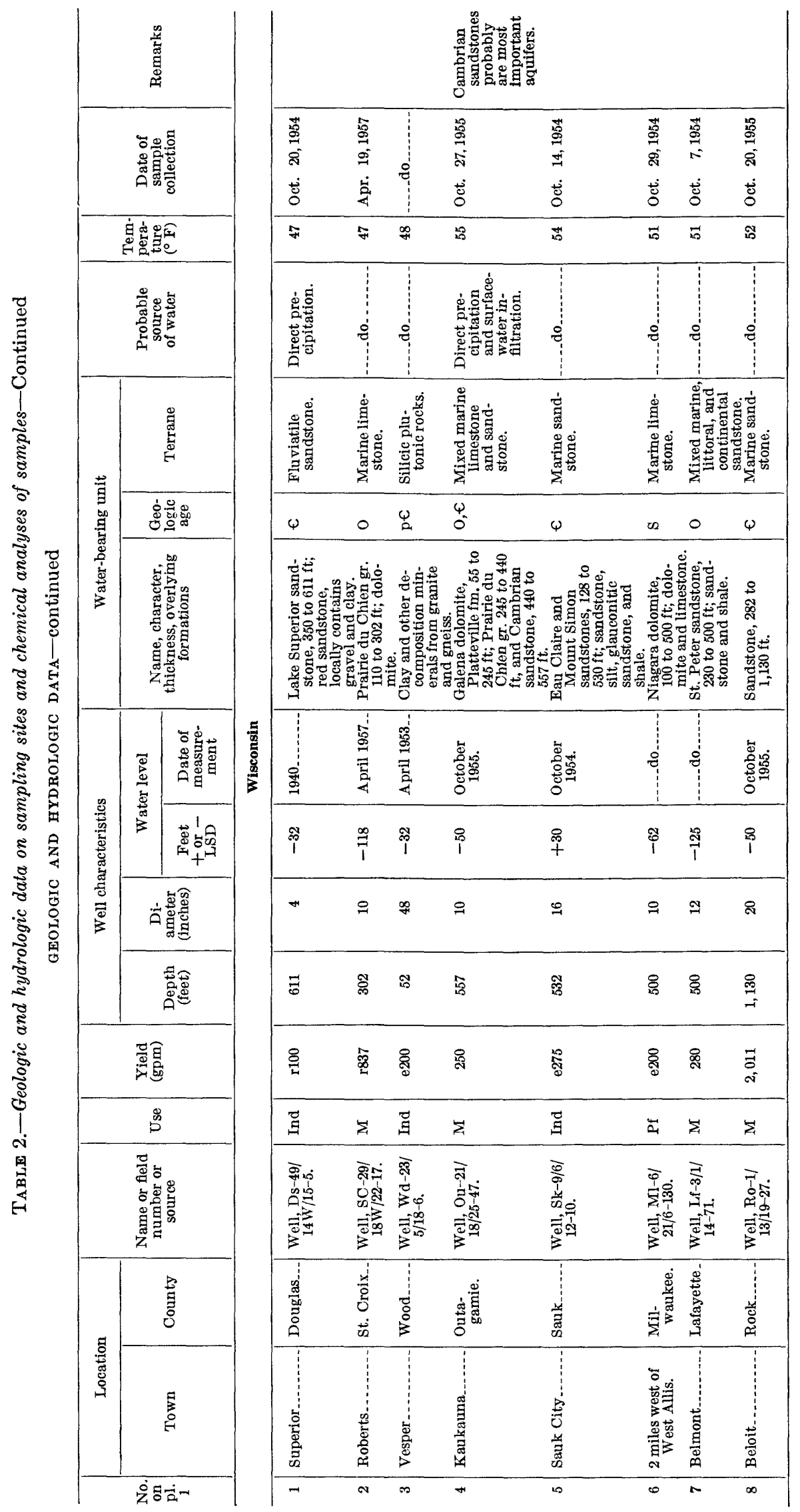


GEOLOGIC, HYDROLOGIC, AND CHEMICAL DATA
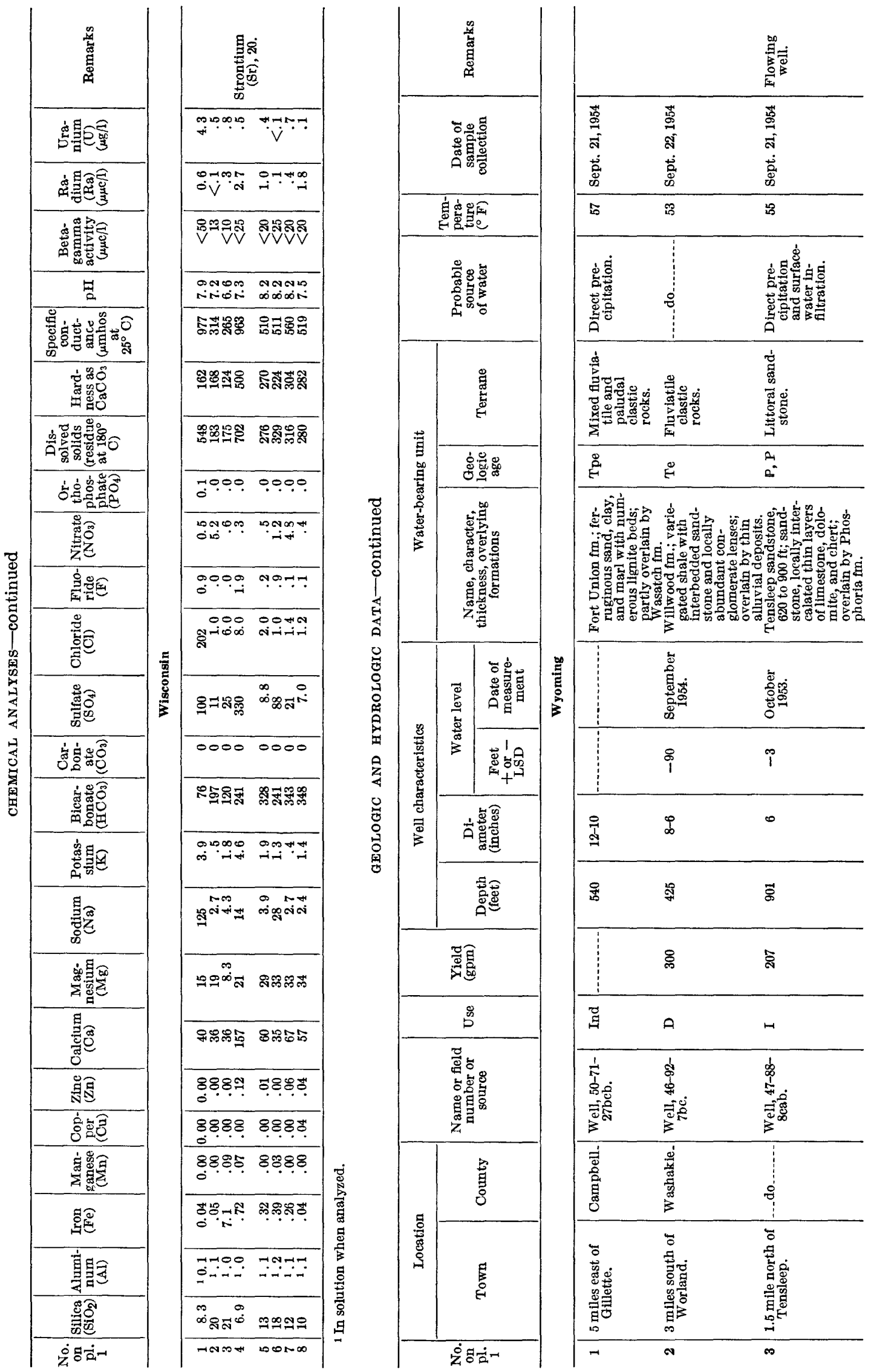


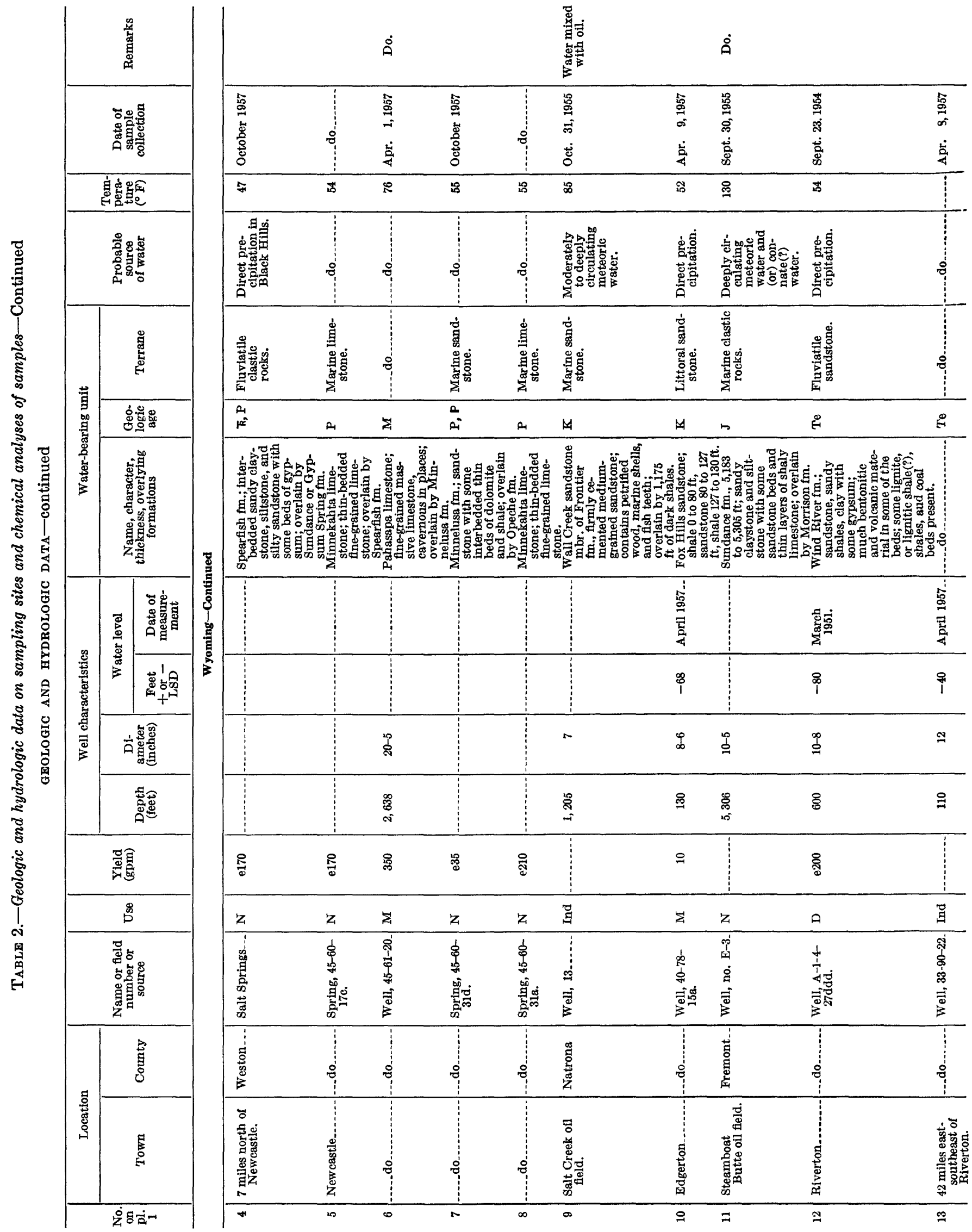


GEOLOGIC, HYDROLOGIC, AND CHEMICAL DATA

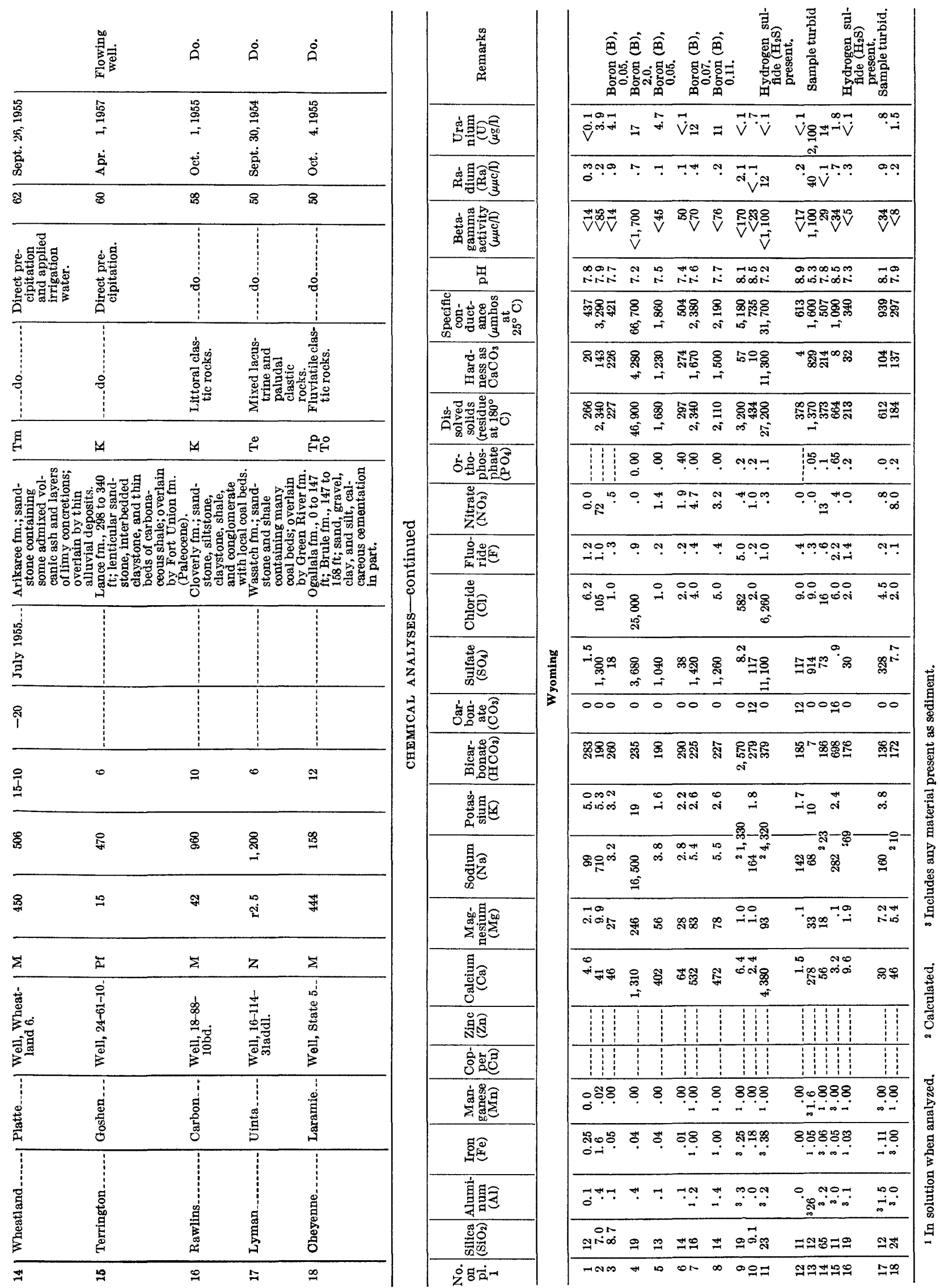


